\title{
The Arctic rift system and the boundary between the Eurasian and North American lithospheric plates: New insight to plate tectonic theory
}

\author{
A. F. Grachev \\ United Institute of Physics of the Earth, Russian Academy of Sciences, Moscow
}

\begin{abstract}
"Tuynianov used to tell, that there are investigations which under the correct study lead to wrong results and there are such ones which under the invalid observations lead to proper results" [L.Ginzburg, 2002, p. 12].
\end{abstract}

\begin{abstract}
The Arctic rift system includes the Mid-Arctic Gakkel Ridge, the Laptev Sea continental margin and the Moma rift. The Gakkel Ridge is the world's slowest spreading mid-ocean ridge with spreading rates ranging from $1.2 \mathrm{~cm} /$ year to $0.6 \mathrm{~cm} /$ year in the southernmost part close to the Laptev Sea. The distinctive feature of the Gakkel Ridge consists of the butt junction with the Laptev sea passive continental margin and such type of junction has never been observed all over the world. The available geological and geophysical data allow to trace how the sea-floor spreading in the Eurasian basin transforms to the rifting on the Laptev Sea continental margin. The Moma rift as the third element of the Arctic rift system develops in the unsteady stress field conditions. Key point to decipher the geodynamics can be obtained under the study of the recent volcanic activity of Northeast Asia. New data on the helium, strontium, and neodymium isotope systematics and new results obtained from the study of rare and rare-earth elements in lavas of Holocene volcanoes in Northeast Asia suggest that young volcanic features are an evidence of activity of a mantle plume at the earliest stage of its development. Such a geodynamic origin of volcanism is likely to control the stress pattern near the boundary between the Eurasian and North American lithospheric plates. We propose that in Northeast Asia up to now there is an unknown type of the plate boundary induced by incipient mantle plume at very beginning stage. Thus, all previous attempts to represent the boundary between the Eurasian and North American plates in linear form lose their meaning.
\end{abstract}

\section{Introduction}

Since the appearance of plate tectonics the question of a number of plates came to be regarded as the most important and widely debated topics among geologists [Le Pichon et al., 1972; Plate tectonics, 1972; and many oth-

Copyright 2003 by the Russian Journal of Earth Sciences.

Paper number TJE03135.

ISSN: $1681-1208$ (online)

The online version of this paper was published 31 October 2003. URL: http://rjes.wdcb.ru/v05/tje03135/tje03135.htm ers]. In the discussion that follows a number of plates will be enhanced markedly as a result of delineation of so called minor plates (microplates, platelets), although in most cases they represent the simple intraplate lithosphere blocks (for instance, within the Eurasian lithospheric plate the Amur, Okhotsk, China and other microplates have been established [Zonenshain and Savostin, 1979]).

It must be emphasized that in some papers continental rifts are regarded as a divergent or constructive plate boundaries [Zonenshain and Savostin, 1979; and others]. This is contradictory to basic principles of plate tectonics. The earth's crust keeps all characteristics beneath the continental rifts, the only change is a decrease of thickness as a result of extension. Actually, as Le Pichon et al. [1973] pointed out, 


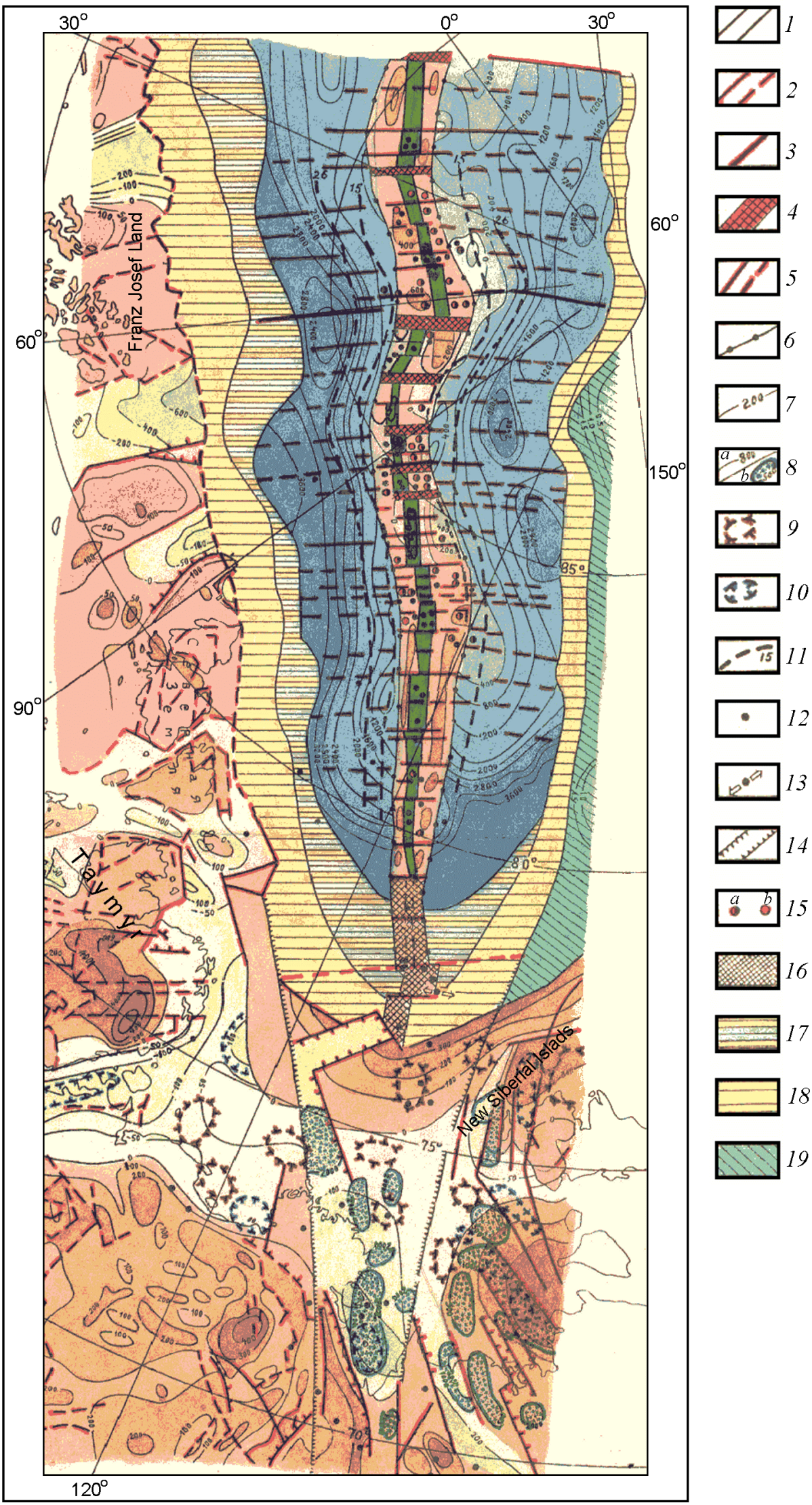


continental rifts are the intraplate structures rather than constructive plate boundaries.

At present we recognize three types of junction between the Mid-Oceanic Ridges and continents. The first case refers to the western North America where the East Pacific Rise goes to the Gorda and Juan de Fuca Mid-Oceanic Ridges through the San-Andreas transform fault. The second one includes the triple junction structure in Afar, Ethiophia, where the Sheba Ridge (the extension of the Mid-Oceanic Carlsberg Ridge) links with the Main Ethiopian Rift and the spreading axis of the Red Sea. And at last the third case includes the Mid-Arctic Gakkel Ridge that has an edge joint with the Laptev Sea continental margin and together with the Moma rift all these units form the Arctic rift system.

One of the postulates of plate tectonics says that all lithospheric plates must be encircled by some closed curve on the Earth's surface. Because the Mid-Arctic Gakkel Ridge marks the boundary between the Eurasian and North American plates, the question how the plate boundary goes to the south from the Gakkel Ridge ending onto North-Eastern part of the Eurasian continent is by no means clear.

\section{Historical Background}

After discovery of the world system of the Mid-Oceanic Ridges at the end of 50's in the Atlantic, Pacific and Indian oceans, the existence of similar ridge in the Arctic ocean has not been known. In 1954 Ja. Ja. Gakkel Gakkel [1957] predicted the occurrence of submarine ridge in the Eurasian basin on a basis of a rare set of bathymetric data, however only B. Heezen in 1961 could cite the exhaustive evidences that this ridge really exited. He also proposed that Pri-Verkhoyansk foredeep was a continental extension of the Gakkel Ridge [Heezen and Ewing, 1961).

Independent from above mentioned authors A. F. Grachev concluded that the Moma trough in Chersky mountain system is the most probable continuation of the boundary between the Eurasian and North American lithospheric plates. Later the special field studies confirmed the rift nature of the Moma trough and allowed the Moma rift zone to be distinguished [Grachev, 1973, 1977; Grachev et al., 1970].
The latter, together with the Gakkel Ridge and Laptev Sea passive margin form the Arctic Rift System (ARS).

Such a point of view was widely appraised in geological and geophysical literature [Avetisov, 1993; Chapman and Solomon, 1976; Conant, 1973; Cook et al., 1987; Fujita et al., 1990a, 1990b; Gramberg et al., 1990; Minster et al., 1974; Pitman and Talwani, 1972; Zonenshein and Savostin, 1979; and many others].

\section{The Mid-Arctic Gakkel Ridge}

The Gakkel Ridge is situated in the Eurasian basin of the Arctic ocean and represents the direct extension of the system of the Mid-Oceanic ridges in the North Atlantic and Norway-Greenland basin through the Mona and Knipovich Ridges. It divides the Eurasian basin into two equal parts and its coincidence with the median line is better than in the other known ridges [Grachev and Naryshkin, 1978]. This ridge is the world's slowest spreading mid-ocean ridge with spreading rates ranging from $1.2 \mathrm{~cm} /$ year to $0.6 \mathrm{~cm} /$ year in the southernmost part close to the Laptev Sea.

The Gakkel Ridge extends more than $1700 \mathrm{~km}$ into the Arctic Ocean from the Spitzbergen to the Laptev continental margin and is reflected in topography as a linear arch whose width decreases to the Laptev Sea. It loses expression in topography as it approaches the continental rise at $79^{\circ} \mathrm{N}$ and to the southwest it is slightly reflected in the ocean floor and can be traced as a rise of a basaltic layer [Grachev and Karasik, 1974] (Figure 1).

Based on the study of magnetic lineations in the Eurasian basin Karasik [1974] and Vogt et al. [1979, 1981] calculated that rates of spreading of $0.5,0.32,0.30-0.59 \mathrm{~cm} / \mathrm{yr}$ for the time intervals bounded by $0,10,20,38-51 \mathrm{~m} . \mathrm{y}$. before present. Near the Laptev Sea the magnetic field intensity falls and its structure becomes more simple. Due to the anomaly confluence, the number of magnetic anomalies decreases from 47 to 6 [Karasik, 1980; Kovacs, 1983] (Figure 2). At the southern end of the Gakkel Ridge the magnetic field pattern is characterized by an absence of a polarity differ-

Figure 1. Map of neotectonics of the Eurasian basin and the adjacent margins [Grachev and Karasik, 1974 with changes]. 1 - rift valley of the Gakkel Ridge; 2 - transform faults on oceanic crust; 3 -transform faults separating areas of a single magnetic province; 4 - zones of transform faults; 5 - faults on the continental crust; 6 - boundaries of the Gakkel Ridge; 7 - isolines of the neotectonic vertical movements; $8 \mathrm{a}$ - isopachs of sedimentary cover for the oceanic basins; $8 \mathrm{~b}$ - isopachs of sedimentary cover for the Laptev Sea shelf; 9 - local neotectonic uplifts; 10 - local neotectonic subsidence; 11 - isochrones of oceanic crust (m.y.); 12 - earthquakes epicenters; 13 - stress pattern in earthquake foci; 14 - area of tension of the Earth's crust; 15a - concordant submarine volcanoes; 15b - discordant submarine volcanoes; 16 - the buried spreading zone of the Gakkel Ridge beneath the sedimentary cover of the Laptev Sea continental margin; 17 - foredeep compensated by deposition of sediments; 18 - transition zone between continental and oceanic crust; 19 - displaced and submerged parts of the former Barents-Kara sea shelf (Lomonosov Ridge). 


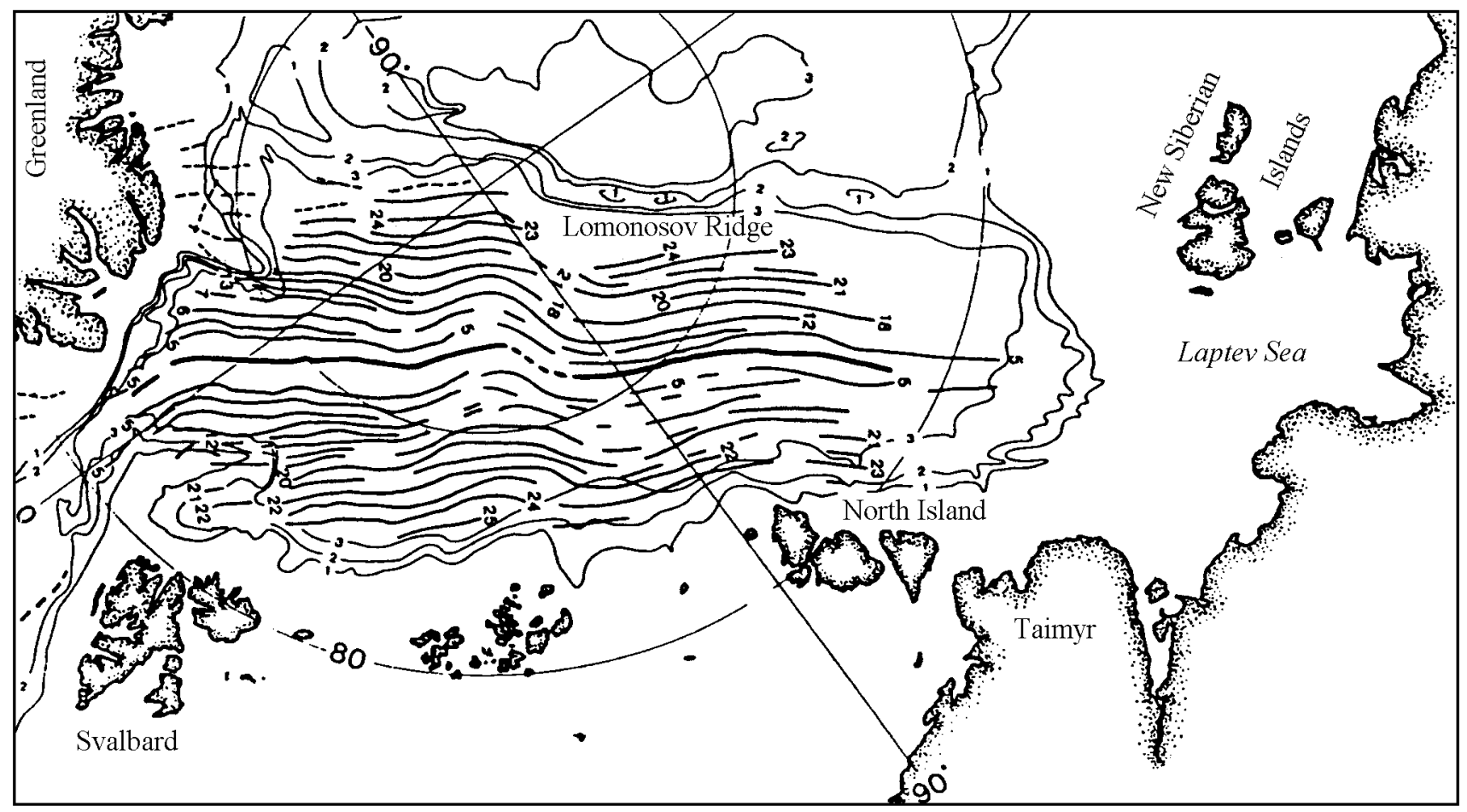

Figure 2. Magnetic lineations pattern of the Eurasian basin [Kovacs, 1983].

ence. Thus all signs of the ocean-spreading magnetic field disappeared at this place [Rzhevsky, 1975] (Figure 3). The spreading rate decreases from $0.6-0.7 \mathrm{~cm} / \mathrm{yr}$ in the central Garrel Ridge to $0.3 \mathrm{~cm} / \mathrm{yr}$ in the southernmost part [ Grachev and Karasik, 1974]. The latter value is the lowest rate known for the world system of spreading ridges. In the Laptev Sea separation velocity must be about $0.1 \mathrm{~cm} / \mathrm{yr}$.

Thus, sea-floor spreading on the southern ending of the Gakkel Ridge is followed by extension of the continental crust, resulting in crustal thinning. The single deep seismic sounding along the profile from the Lena river mouth to the Yana mouth through the northern tip of Buor-Haya cape proved the thinning of continental crust and the existence the low velocity mantle $\left(V_{p} 7.5 \mathrm{~km} / \mathrm{s}\right)$ beneath the basaltic layer of thickness about $20 \mathrm{~km}$ [Kogan, 1974].

It is important to note that there are no islands on the Gakkel Ridge that is a consequence of a low rate of spreading and volcanic activity. There are also no islands within the Gorda, Juan-de-Fuca and Explorer ridges. The first data of chemistry of volcanic rocks have been obtained recently during the ARCTIC '91 expedition aboard RV Polarstern to the Central Arctic Ocean [Muhe et al., 1993, 1997]. The rocks (volcanic glasses) recovered from the southern slope of the rift valley are relatively unfractionated primitive basalts with E-MORB trace element compositions of early Quaternary age.

It is interesting to note in this connection the first evidence of a high hydrothermal activity in the southern termination of the Gakkel Ridge $\left(77^{\circ} \mathrm{N}, 125^{\circ} \mathrm{E}\right)$. Here in the core sample the remnants of bivalavia Arcivesica sp. nova of the Vesicomyidae family have been found [Kim et al., 1997]. Such fauna is typical for hydrothermal venting on the MidOceanic Ridges.

Having all signs of the Mid-Oceanic Ridges, the Gakkel Ridge has one of the slowest spreading rates of all midoceanic ridges that are responsible for the many features of topography and structure. The last results of geophysical investigations confirm this conclusion [Coakley and Cochran, 1998; Weigelt and Jokat, 2001]. Gravity studies estimate a crustal thickness between 1 and $4 \mathrm{~km}$ for the Gakkel Ridge [Coakley and Cochran, 1998], much lower than the canonical 6-7-km crust observed beneath the remainder of the Earth's oceans. Such thin crust under axial zone suggests the low magma supply, low heat flow as a result of the block structure of axial zone of the ridge with very deep rift valley more then $5000 \mathrm{~m}$ depth.

However the most important and distinctive feature of the Gakkel Ridge consists of the butt junction with the Laptev sea passive continental margin [Grachev, 1982; Grachev and Karasik, 1974; Karasik and Grachev, 1977]. Such a type of a junction has never been observed in other known cases, where the spreading axis is parallel to passive continental margin.

Close to the Laptev sea continental slope the rate of a deposition of sediments is higher than the rate of the ridge's uplift and one can observe only the outcrops of the oceanic basement cutting the sedimentary cover (Figure 4). However displacement of the Quaternary sediments along normal faults proves the very young age of tectonic movements (Figure 5). 


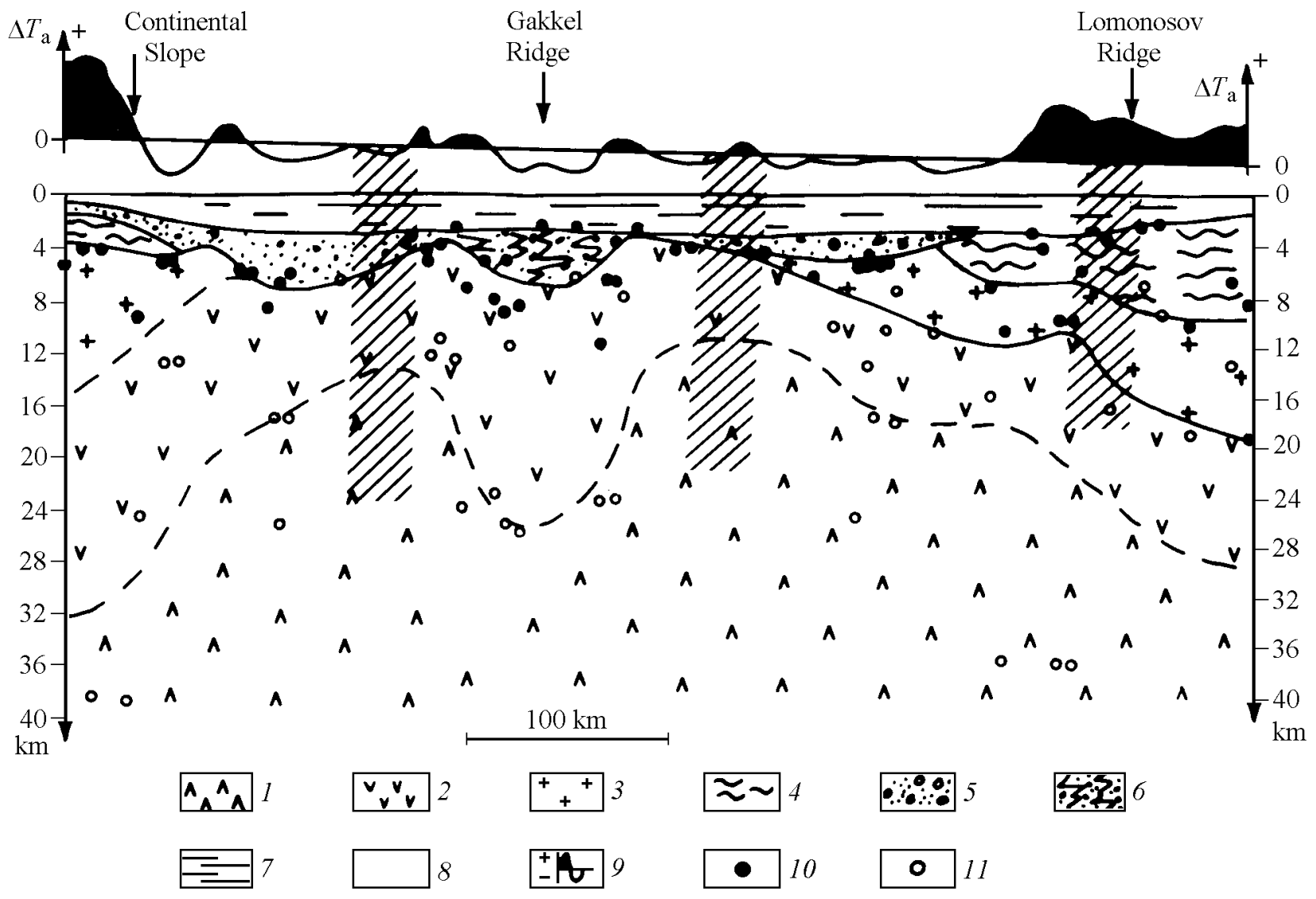

Figure 3. Crustal sections of the southern part of the Gakkel Ridge obtained by airborne magnetic data [Rzhevsky, 1975]. 1 - upper mantle, 2 - basaltic layer, 3 - granitic layer, 4 - consolidated deposits, 5 - unconsolidated deposits, 6 - volcanic-sedimentary strata of the rift valley, 7 - water, 8 - weakened zone of uncertain genesis, 9 - plot of anomalous magnetic field $\Delta T_{a}, 10$ - depth of the upper edges of magnetic bodies, 11 - depth of the lower edges of magnetic bodies.

\section{The Laptev Sea Continental Margin}

The Laptev Sea is a shallow epicontinental basin with depths less than $50 \mathrm{~m}$. The sea floor has a smooth topography with slightly expressed slope to the Eurasian basin. Trend analysis of bathymetric data shows (Figure 6) that isoline pattern of depths (in meters) detects two distinct directions: northeastern isolines passing from Ust'-Chatanga trough and northwestern isolines passing through the Ust'-Lena trough [Grachev and Mishin, 1975]. These two structural lines are confirmed by the rose diagram of the Siberian platform fault strikes [Mezvilk and Murzina, 1972].

On the map of a local component (residuals as a difference between the trend map and real topography) on can see the East-Laptev, Ust'-Yana and South Laptev uplifts, expessed in positive deviations and the Ust'-Lena, West-Laptev and Belkovsky troughs as negative ones (Figure 7).

The northernmost isolines within the Laptev Sea floor outline the continental slope and directly join it. To the south it goes into a subsidence area, where pericline of the
Taimyr and Novosibirskaya uplifts are situated to the east and the west. Southward there are the South-Laptev and Ust'-Yana uplifts. A zone of northwest movements, represented by a system of linear depressions assigned to the Ust'-Lena subsidence zone, occurs against this background. The northwest end can be traced toward the continental slope, and at $76^{\circ} \mathrm{N}$ and $124^{\circ} \mathrm{E}$ it joins the northeast striking subsidence zone (a part of the continental slope structure) where the buried extension of the Gakkel Ridge is determined by gravity data and trend analysis of bottom topography (Figure 1).

Thus, the zone of the most distinct tectonic movements of the Laptev Sea is an extension of the Eurasian basin structure. These movements are characterized by the same axis of symmetry. We can obtain approximate outlines of neotectonic and recent crustal movements in this zone if we project southward the boundaries of the Eurasian continental slope.

More valid evidence supporting the structural position of this zone is obtained by defining a pole of rotation with respect to the opening of the Eurasian basin. Its coordinates $\left(72^{\circ} \mathrm{N}\right.$ and $\left.129^{\circ} \mathrm{E}\right)$ determined by Karasik [1980] allow to locate the above mentioned zone in this sector. The most 


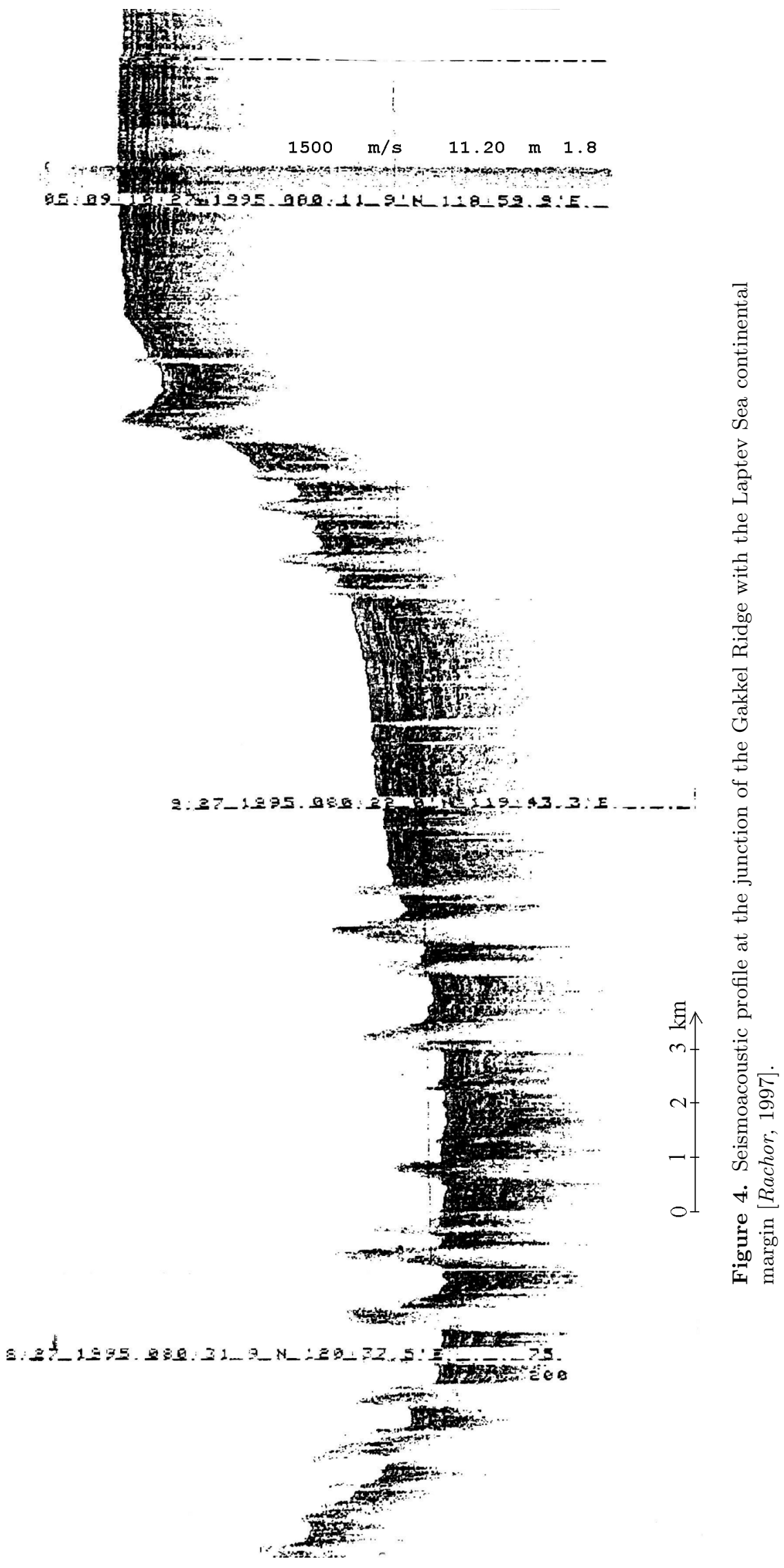




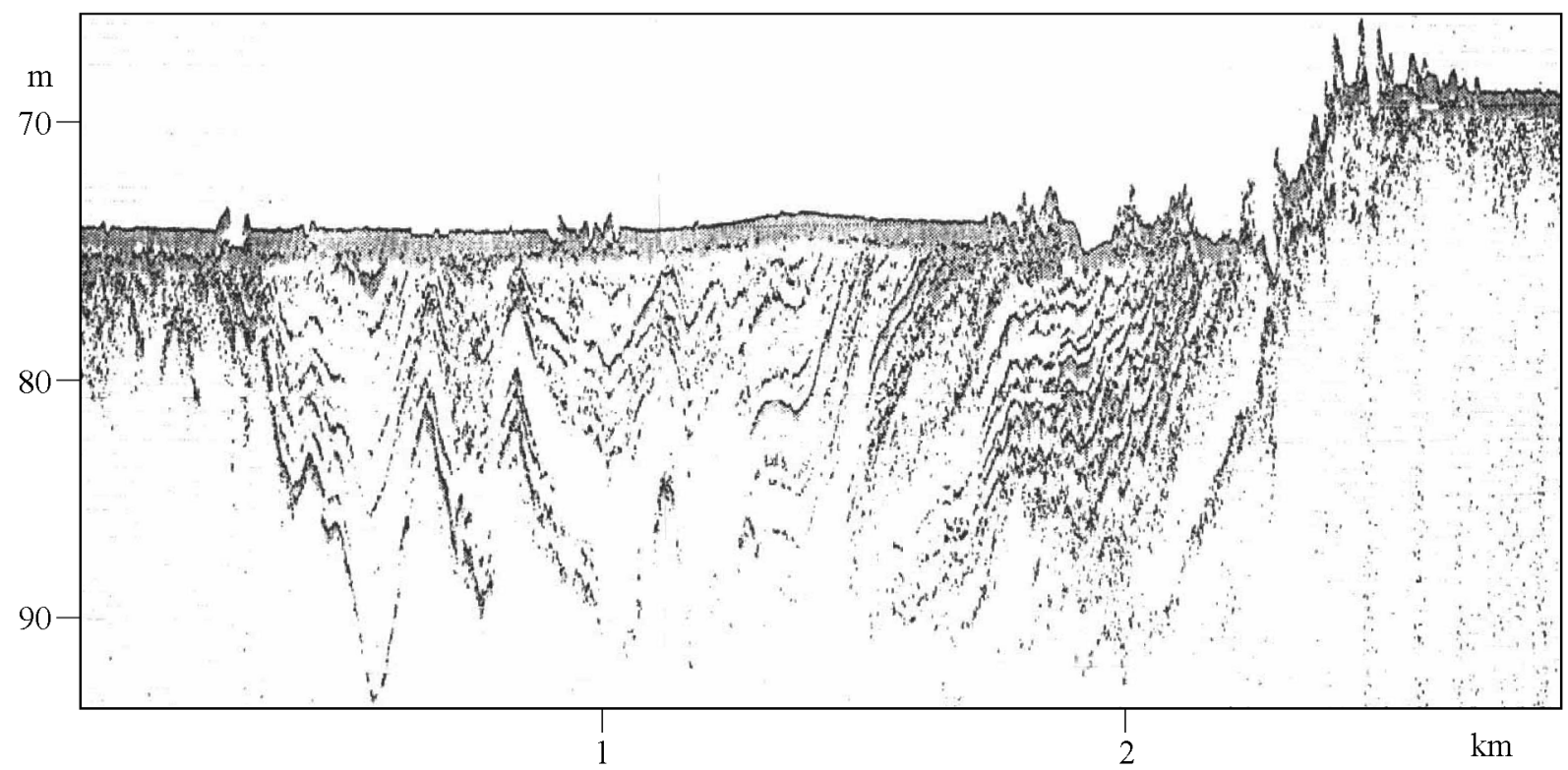

Figure 5. Seismoacoustic profile of the outer part of Laptev Sea shelf. One can see the displacement of the Quaternary sediments along the young normal fault [Rachor, 1997].

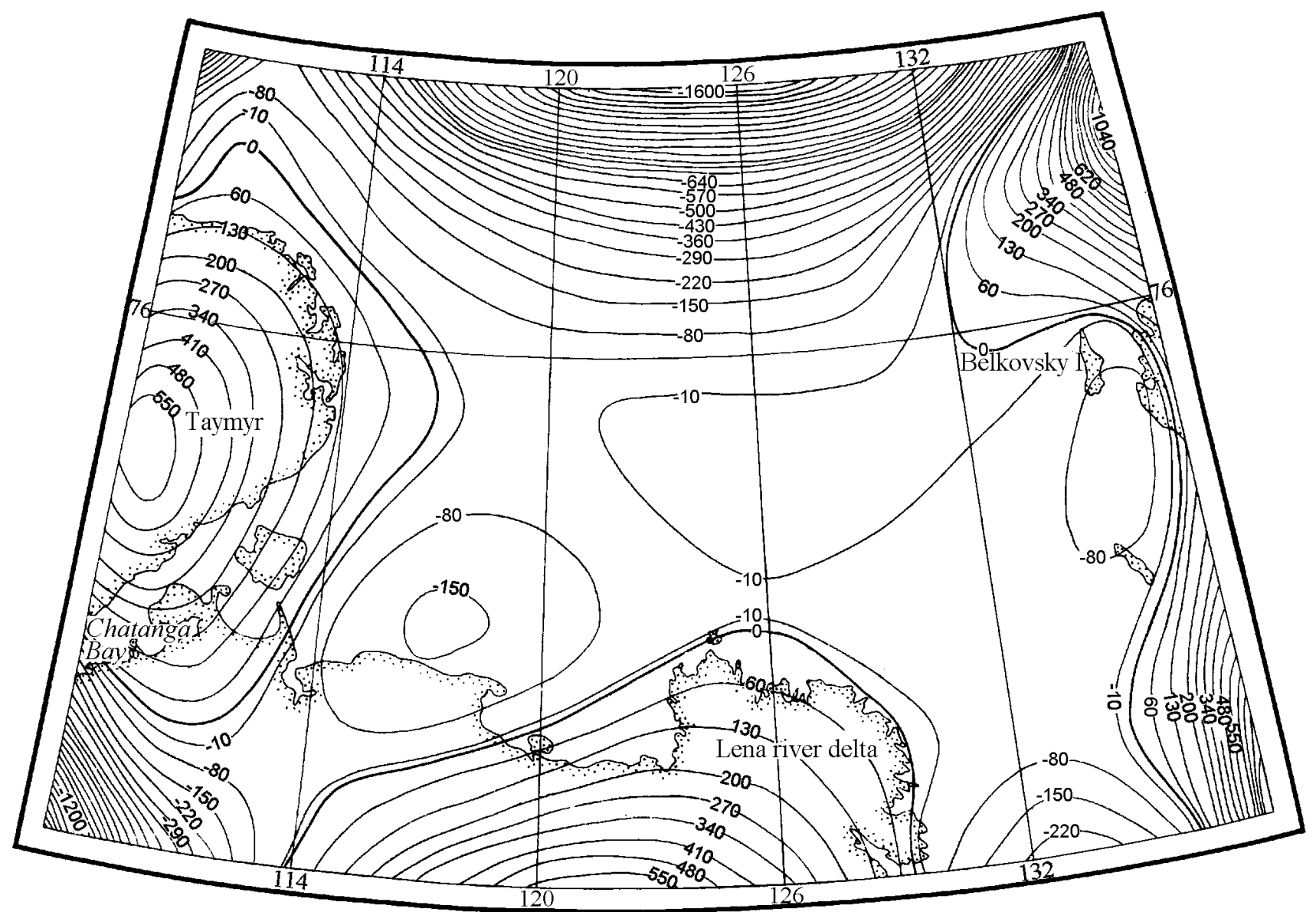

Figure 6. Map of a trend surface of the Laptev Sea bottom [Grachev and Mishin, 1975]. 


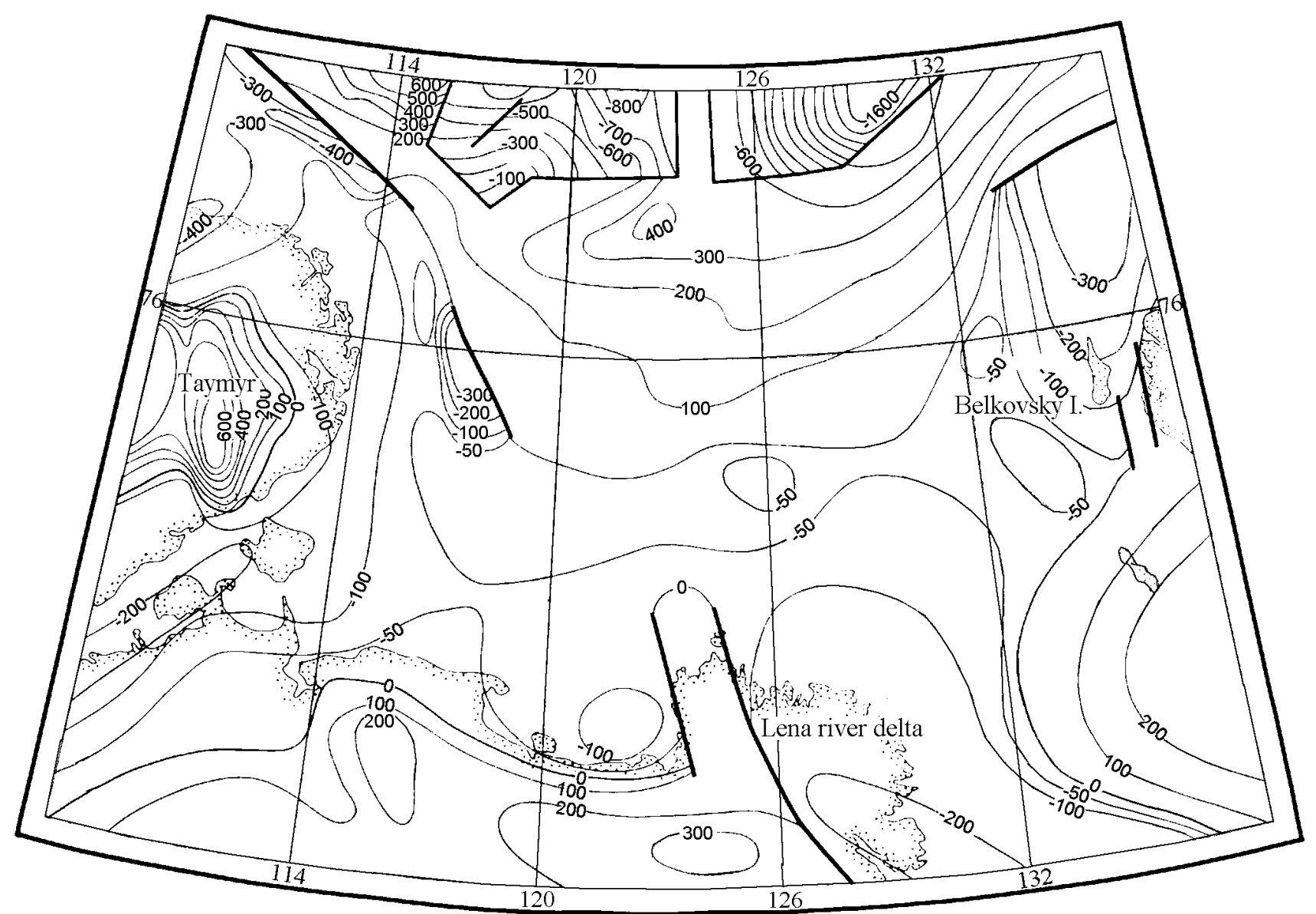

Figure 7. Map of a trend surface deviations from the real depths of the Laptev Sea bottom [Grachev and Mishin, 1975].

part of earthquakes are concentrated within this zone (see below).

Geologic history of the Laptev sea shelf during Cenozoic is not well studied. Available data allow to assume that during the most part of Cretaceous and Paleocene this territory was subjected to planation and formation of the crust of weathering. Such conditions existed during Miocene and Early Pliocene [Paleogeographic..., 1991]. With the beginning of a transgression of $4 \mathrm{~m} . \mathrm{y}$. ago the northern part of the Laptev Sea shelf was covered by sea, and on the rest part of the Laptev Sea a lacustrine and alluvial sediment were deposited (Figure 8). The most prominent tectonic movements with inherited development of uplift and subsidence zones occurred during time span of 3.3-2 m.y. in the central part of the shelf, when the recent structure of the Laptev Sea has been formed. The key neotectonic element on the shelf is the Omoloy graben as a link structure with the Gakkel Ridge which has a length of $400 \mathrm{~km}$ and a width from $20 \mathrm{~km}$ in the north and $35 \mathrm{~km}$ in the south.

New multichannel seismic reflection (MSR) data allow to establish the internal structure of a sedimentary cover [Drachev et al., 1995, 1998; Sekretov, 2002]. The isopachs map of sedimentary cover reveals the linear system of the grabens with the general north-western strike and total thickness of Cenozoic sediments more then $4 \mathrm{~km}$. These grabens run across the shelf and form three systems: western (Ust'-Lena), central (Omoloy) and eastern (Anisin, Bel'kovStanovoy and others) (Figure 9). Although the drilling data are absent and a interpretation of the MSR profiles is ambiguous [Drachev et al., 1998; Sekretov, 2002], the most important conclusion consists in revealing of listric synsedimentary faults (Figure 10). It is highly probable that the grabens in the Laptev sea have developed in a different time span [Drachev et al., 1998], and in such a case the Omoloy graben is the most young structure bearing in mind its high seismic activity.

In adjacent part of land Paleogene and Neogene sediments are found in the Sogo, Kengdey and other grabens in the Northern Verkhoynsky ridge [Bidjiev and Natapov, 1972]. The young listric normal faults are well known in Tiksi and Buor Khaya bays [Imaev et al., 1990] (Figure 11). From graben systems on the Laptev sea to the land, zone of extension becomes more narrow till the complete ending in $70^{\circ} \mathrm{N}, 132^{\circ} \mathrm{E}$. Although the character of seismicity of the Laptev shelf has been discussed by many authors [Avetisov, 1978, 1996; Barazangi and Dorman, 1969; Conant, 1973; 

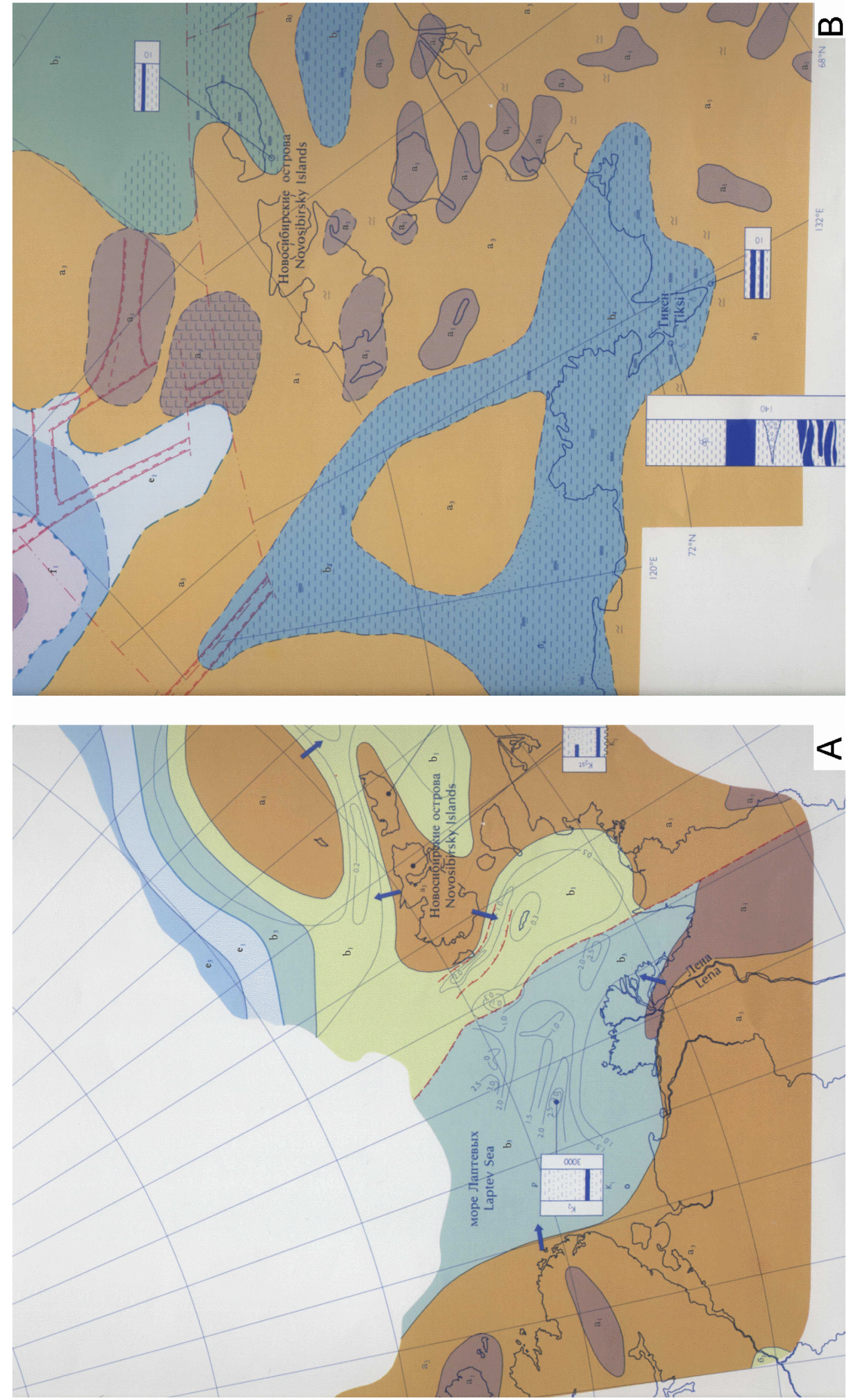

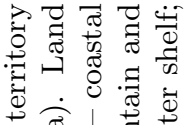
我 1 节苛

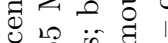

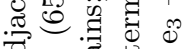

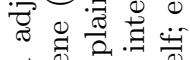
चี


n

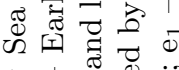

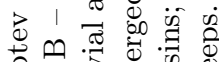

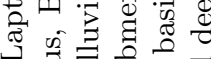
\&

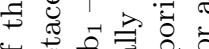

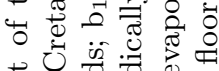

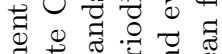

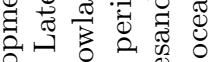
$<$ ए $\tau$. $\frac{\pi}{2} \pi$ 实记

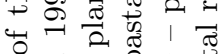
的元造菊 先.

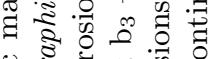
$\because \frac{3}{0} \div$ : 1 ( क्षे 80 is

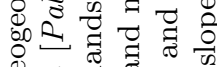

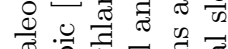
స $\infty$ 过

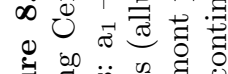

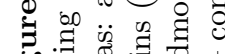

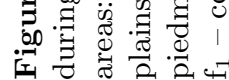




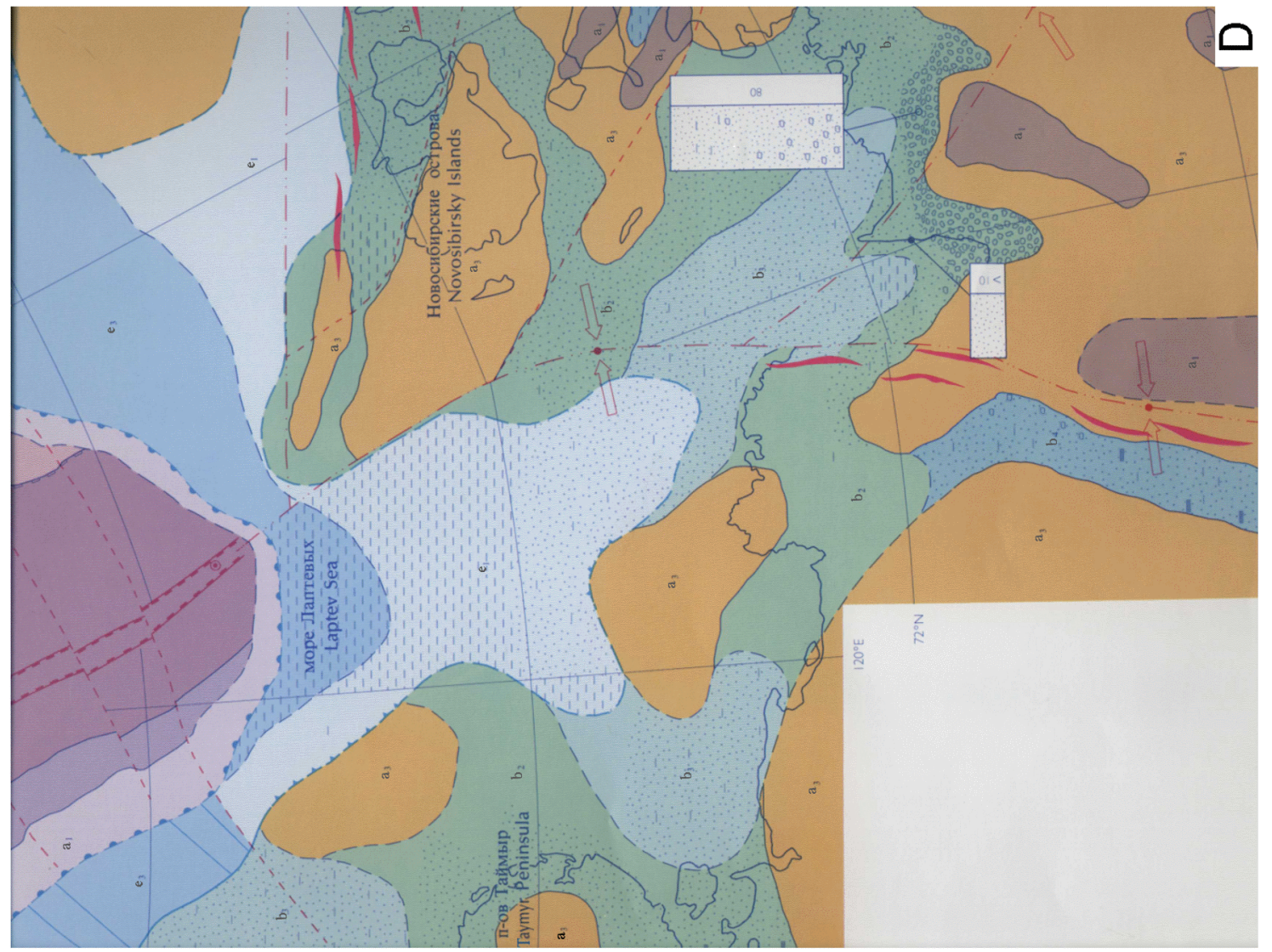

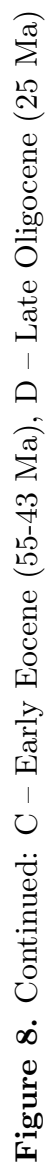

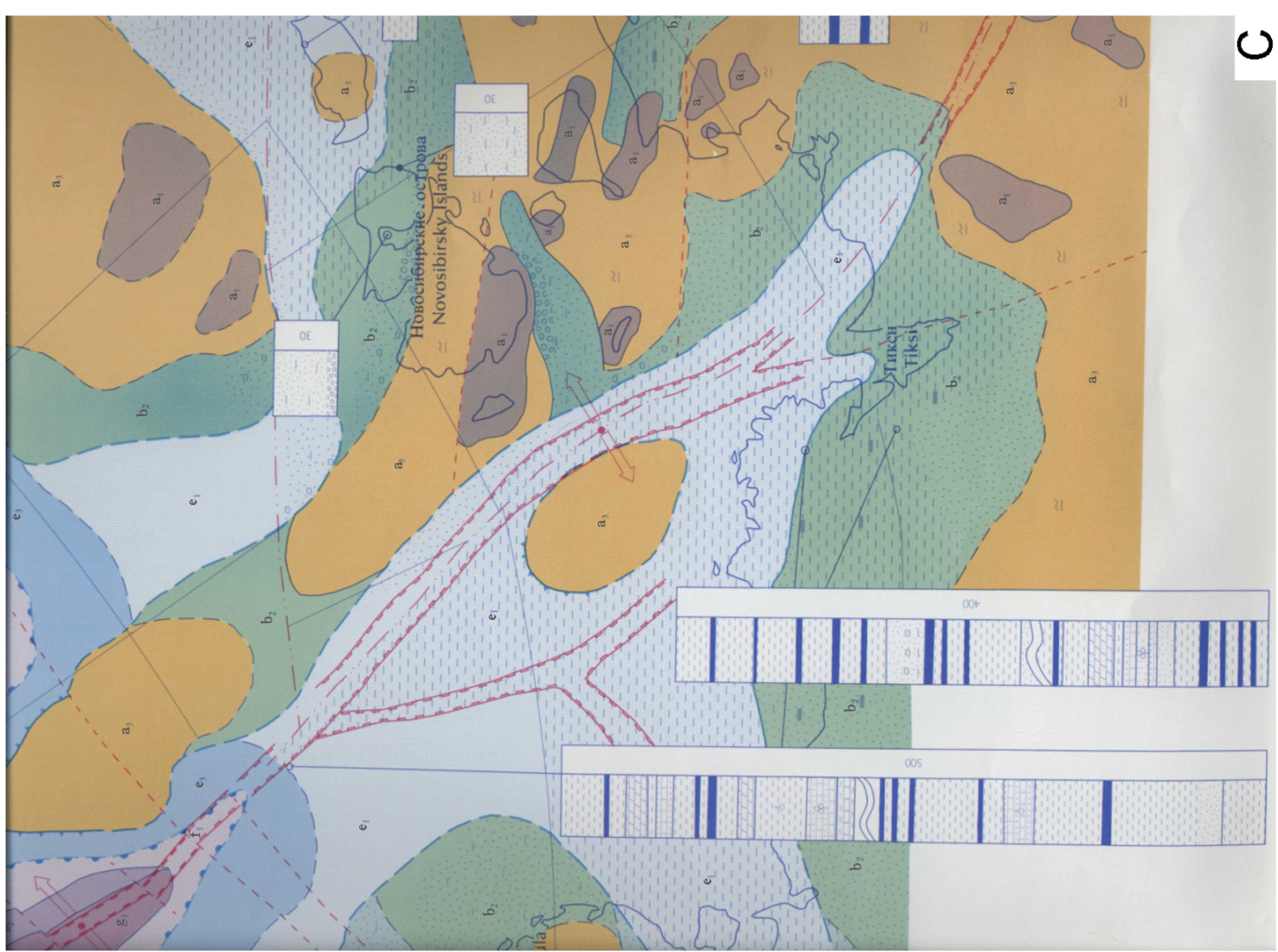




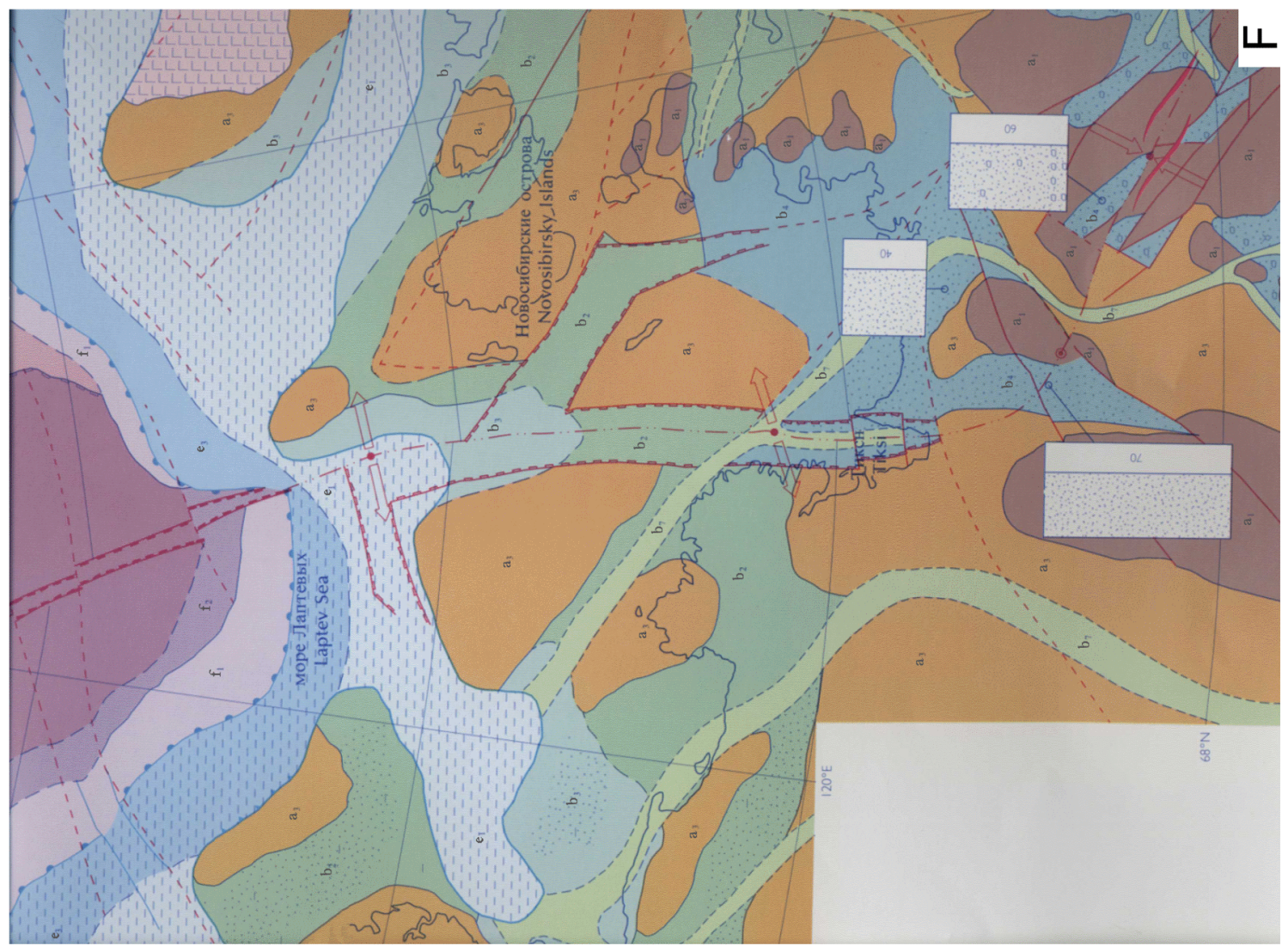

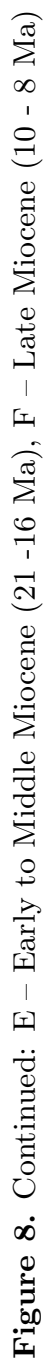

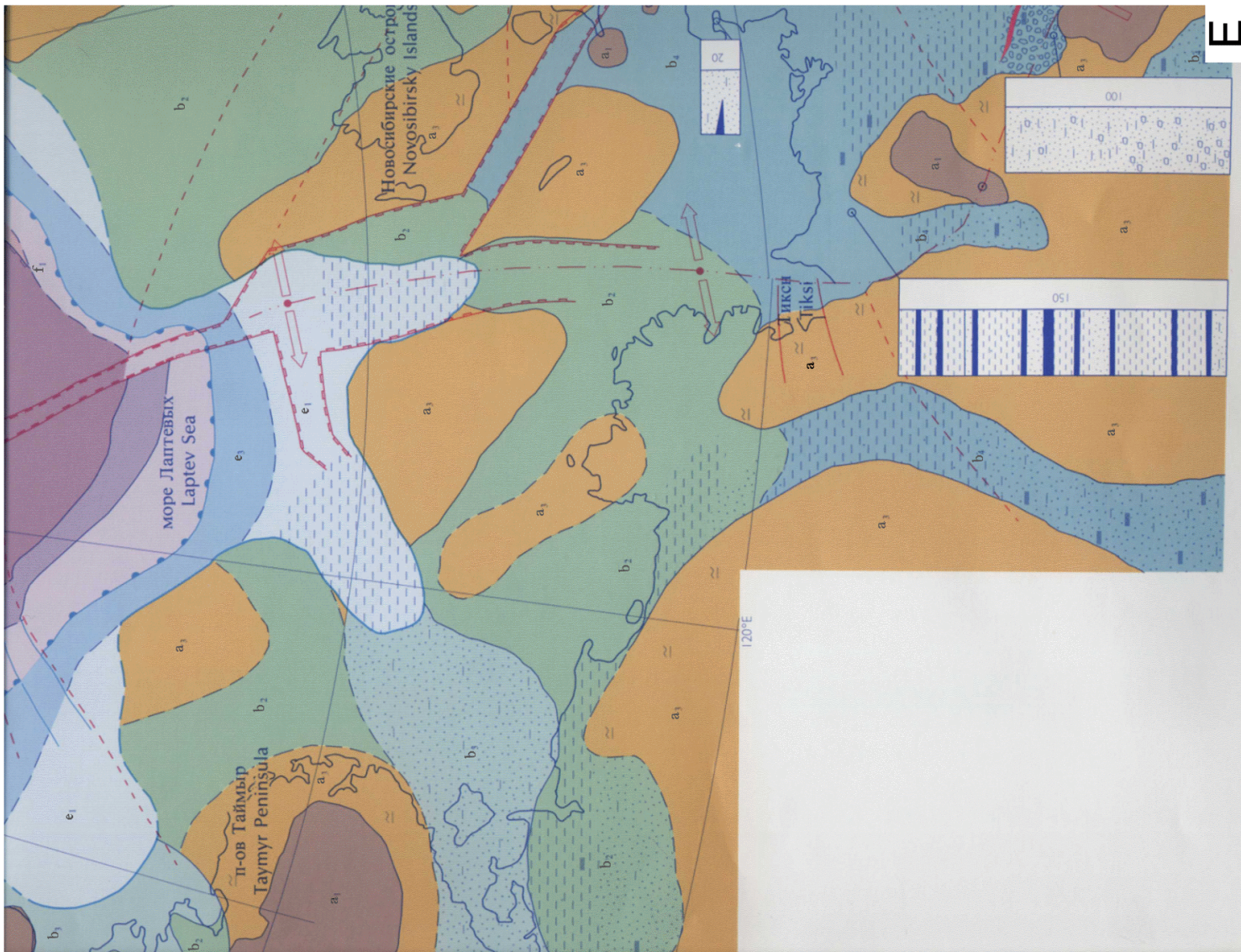




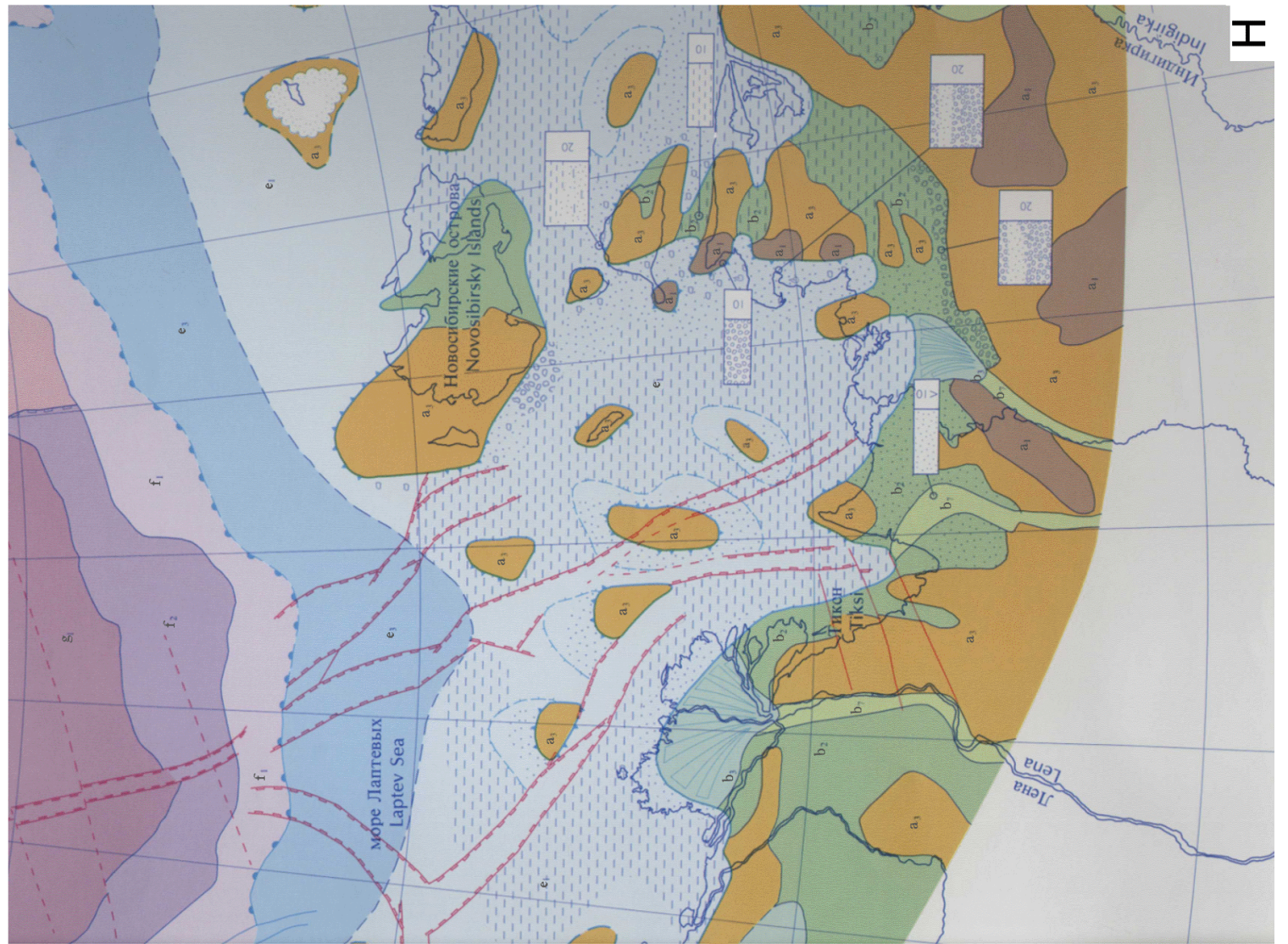

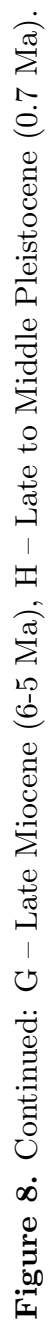

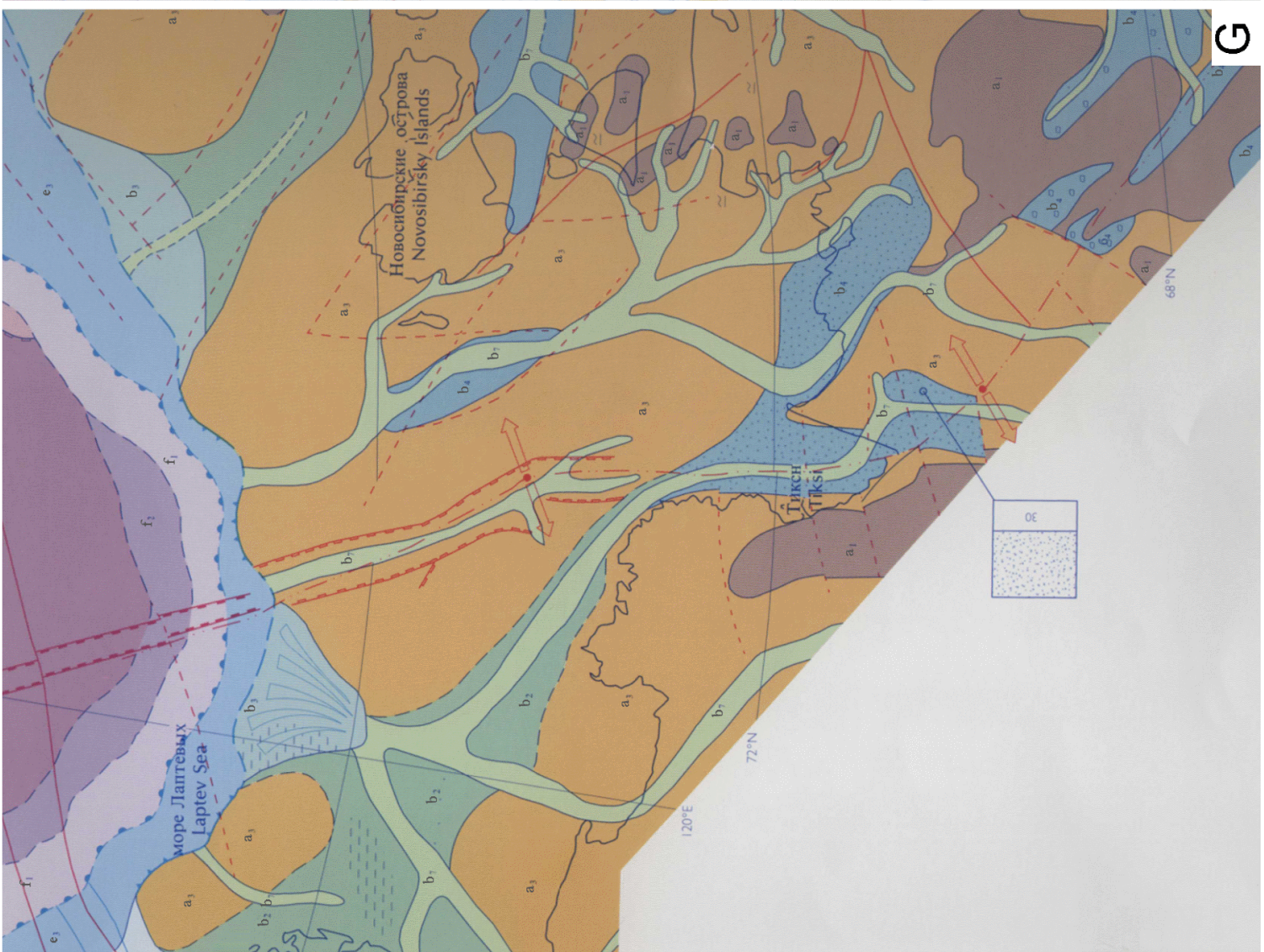




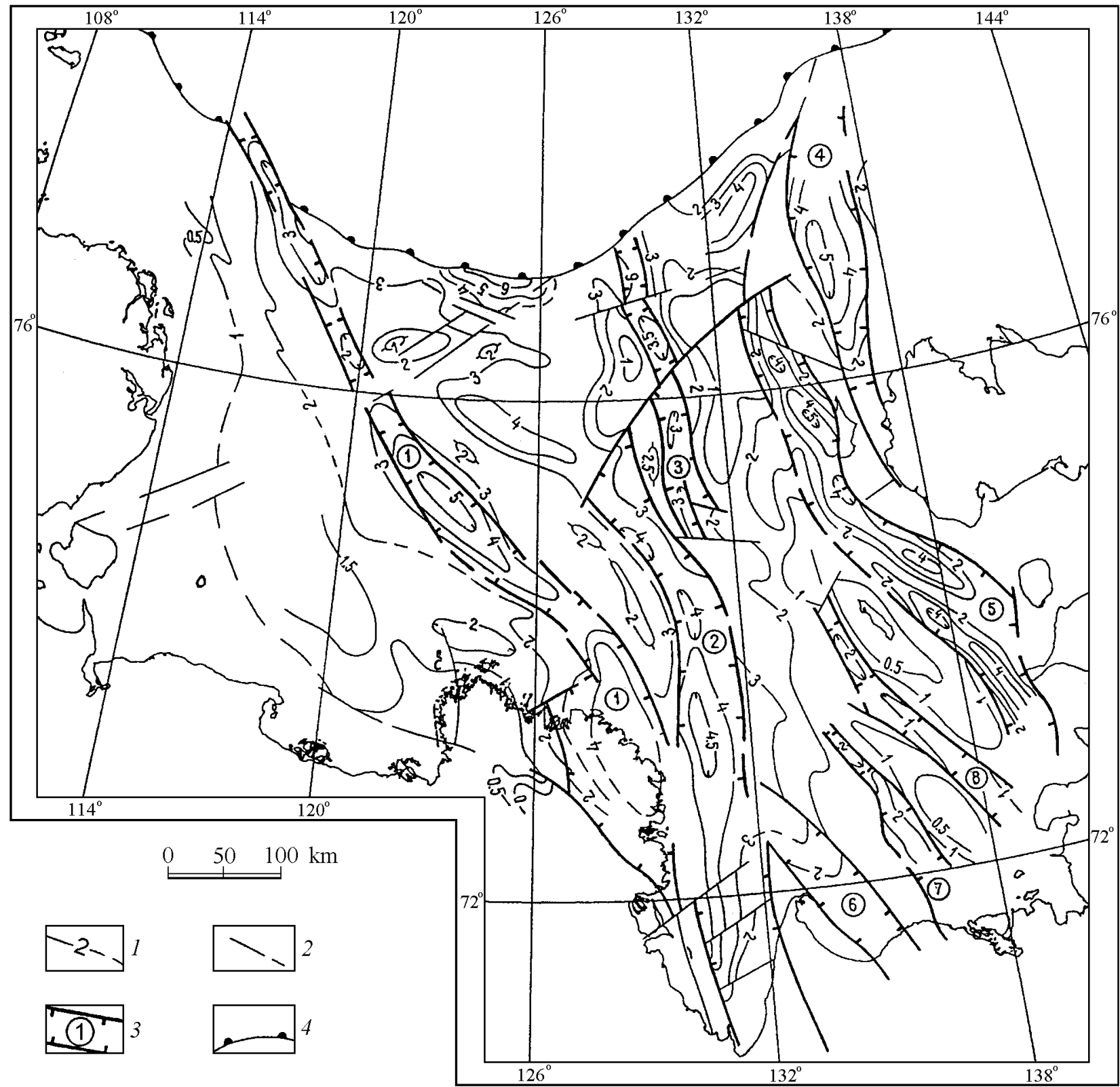

Figure 9. Isopach map of Upper Creataceous-Cenozoic sediments of the Laptev Sea shelf (compiled by B. I. Kim). 1 - isopachs, km; 2 - faults; 3 - grabens (numbers in circles: 1 - Ust' Lena, 2 - Omoloi, 3 - North-Omoloi, 4 - Anisin; 5 - Bel'kov - Svyatoi Nos, 6 - Ust' Yana, 7 - Chondon, 8 - Shiroston); 4 - shelf break.

Franke et al., 2000; Fujita et al., 1993; Koz'min, 1984; Sykes, 1970; and others], nevertheless there are the significant differences in focal mechanisms determination for some seismic events as a result of the limited data. As it follows from the map of earthquake there are two seismic belts: eastern and western ones (Figure 12). The eastern branch with earthquakes magnitudes more than 5 extends from the Gakkel Ridge over through the Omoloi graben to the Buor Khaya bay and is characterized by normal faulting solutions. To the south of $76^{\circ} \mathrm{E}$ the width of this zone increases as a result of a change of the oceanic crust to the continental one. At $70^{\circ} \mathrm{E}$ this seismic zone jumps to the east where at $140^{\circ} \mathrm{E}$ we propose the junction with the seismic belt of the Moma rift through the West-Poluosny system of grabens [Grachev, 1982] (Figure 13). The north-western branch goes from the Buor Khaya Bay to the Taimyr Peninsula and is dominated by strike-slip type solutions [Franke et al., 2000]. Thus, the available geological and geophysical data allow to trace the 

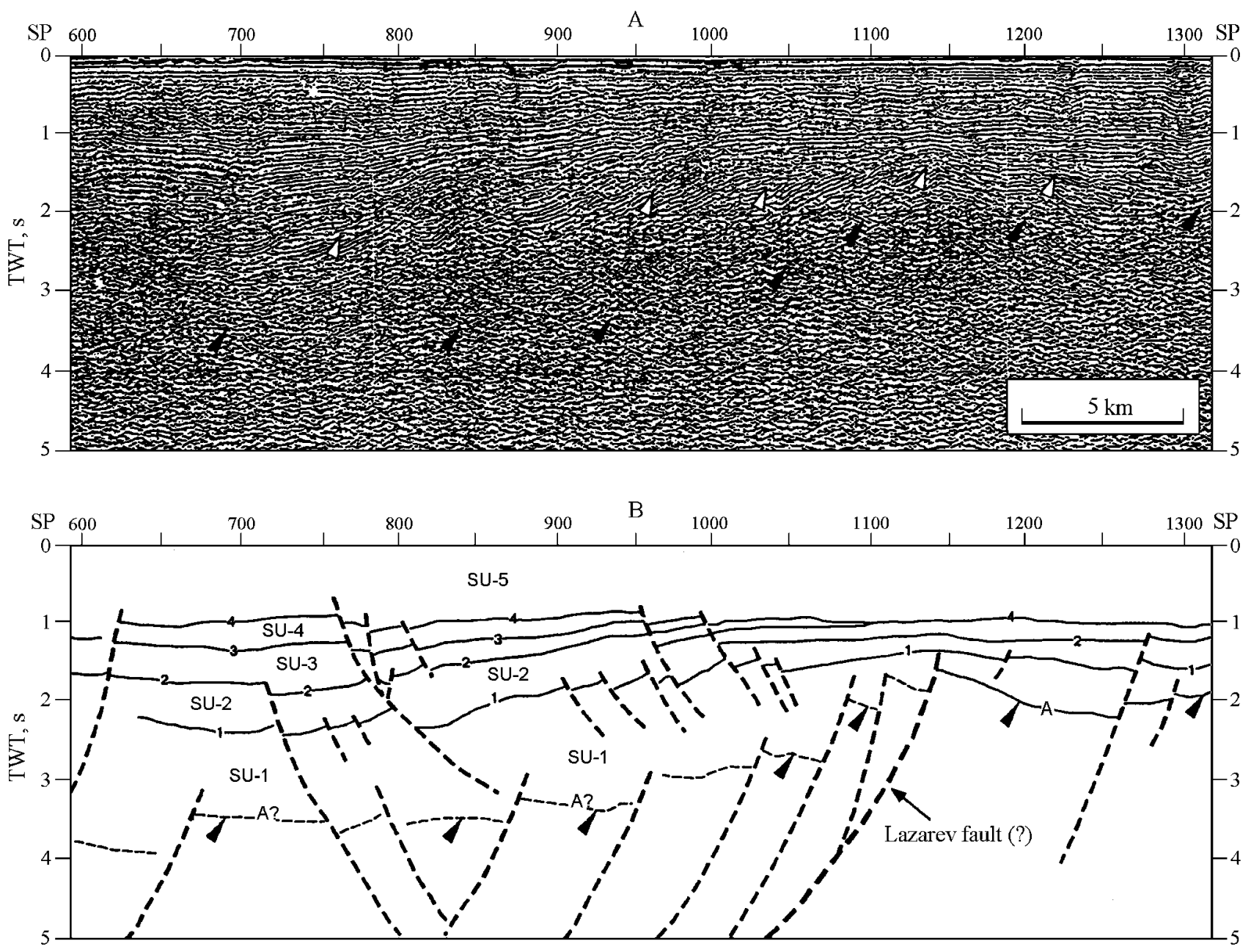

Figure 10. Fragment of the MKS profile LARGE006 (A) and its interpretation (B). The top of acoustic basement is marked as A. SU-1 and others are the seismic stratigraphic units; SB - shot points [Drachev et al., 1998].

rift zone on the Laptev Sea shelf as a direct extension of the spreading in the Eurasian basin [Grachev and Karasik, 1974; Grachev, 1982, 2000; Drachev, 1999; Sekretov, 2002].

\section{The Moma Rift}

The Moma rift is situated within the Mesozoic folded belt of the Chersky ridge and stretches in the northwest direction from the Seimchan-Byiandyn depression in the south to the Laptev Sea in the north within distance of $1200 \mathrm{~km}$ [Grachev, 1973, 1982, 2000]. The Moma rift has developed within the Mesozoic fold belt in North-East Asia. The neotectonic structure of the rift is highly inherited from Mesozoic folded basement in the southeast and superimposed in the north-west in the Polousny Range where the Quaternary fault system stretches into a tension structure of the Laptev Sea floor.
The Moma rift is represented by a system of troughs which consist of two major linear depressions with surroundings rift shoulders, as the Chersky ridge in the west-southwest (Figure 14) and the Moma, Andrei-Tas and Selennyakh ridges in the northeast (Figure 15). Taking into account the problem of the plate boundary between the Eurasian and North American plates it is necessary to determine the key questions. The first one concerns the age of the Moma rift structure, the second one includes the probable connection with the zone of extension in the Laptev Sea shelf.

At first we must note that the stratigraphy of the subaerial Cenozoic sediments of the North-East Asia is based mainly on the palinological analysis and the correlation of the sections based on the pollen study is very complicated due the existence of the rewashed pollen. In my first papers published at the very beginning of 70 s and based of a detailed comparative study of stratigraphy, lithology and facial analysis of Cenozoic sediments two stages were recognized in the history of the development of the Moma rift [Grachev, 1973; Grachev et al., 1967, 1970]. The first (Pliocene to 


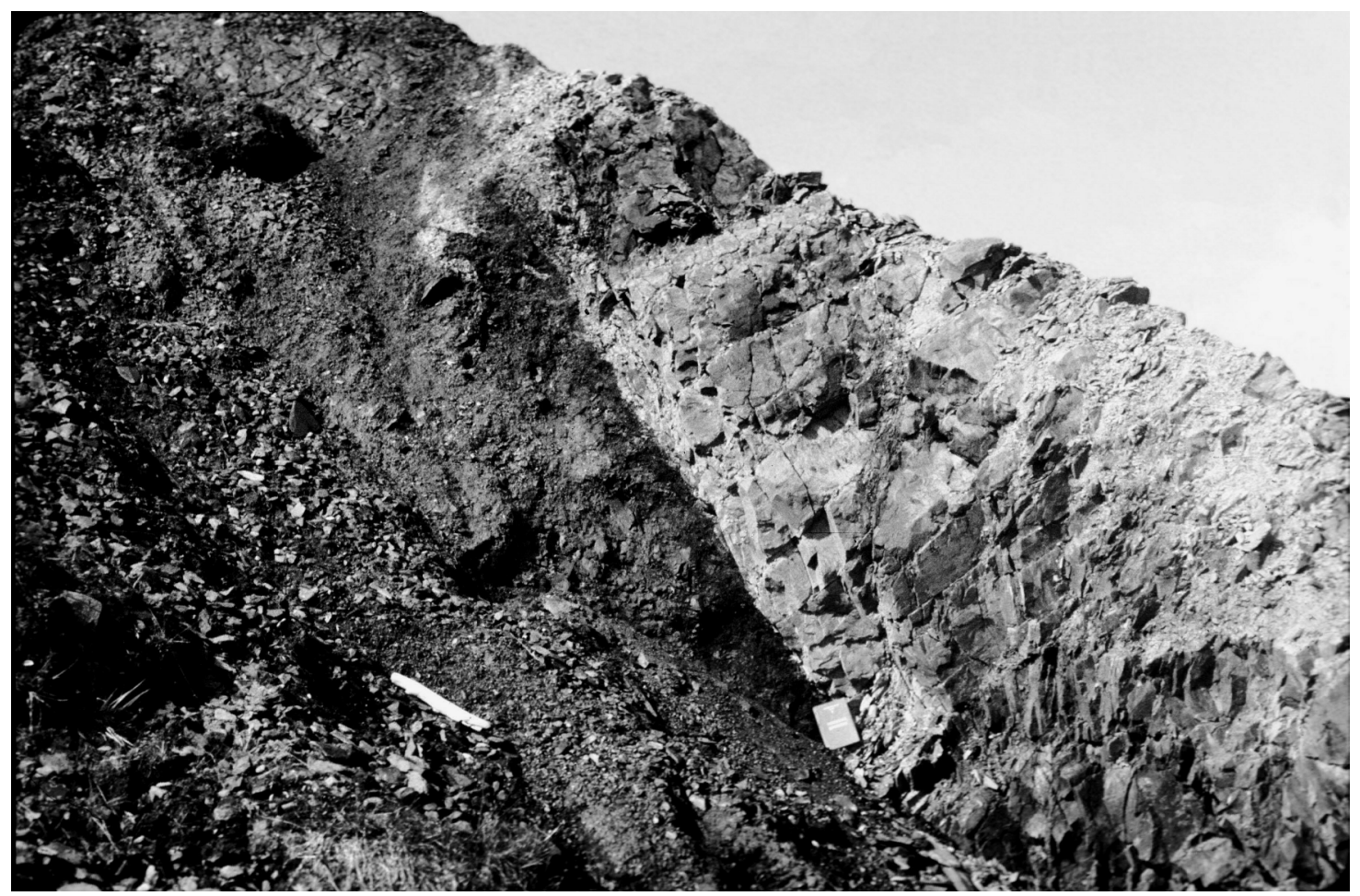

Figure 11. Listric normal fault displaced the Pliocene sediments (mouth of the It-Yurege river, Laptev Sea).

Early Quaternary) is characterized by a deposition of thick, well sorted alluvial-lacustrine sediments. The latter started to develop after cessation of the orogenic movements at the end of Cretaceous. Paleomagnetic investigations and paleogeographic reconstructions have proved that tectonic movements in the north-eastern margin of the Asian continent continued between Late Cretaceous times and 53-50 Ma due of a collision of microcontinents (Kolyma-Omolon and Chukotka, respectively) and long-lasting existing convergent margins of Siberian craton [Oxman, 2003; Parfenov, 1984; Yo-ichiro et al., 2003]. Coarse clastics (molasses) of the MidQuaternary age resting with angular unconformity on the lower unit were deposited owing to the growth of mountain ridges during the second stage. Another evidence of the time span of the Moma Rift formation can be obtained by the study of the recent drainage pattern development. As it was shown by Trushkov [1972], Baranova and Biske [1964] and others the oldest dated terraces refer to the Upper PlioceneEarly Quaternary time. Thus, taking into account the insufficient thickness of molasse the mountain-building processes within the Moma Rift is in its very beginning in comparison with the mature continental rifts such as the Baikal rift and others [Grachev, 1987]. The nature of active faults of the Moma rift has been widely discussed in many papers. These faults have the NW-SE strike and their position is highly inherited from the Mesozoic structural pattern [Merzliakov, 1971]. The one exception is the north-western termination of the Moma rift where the mid-Quaternary West Polousny faults form the superimposed structure and cross-cut the Mesozoic basement.

There are contradicting geological evidences concerning the kinematics of active faults - normal faults with strikeslip component, strike-slip faults or thrust faults [Artemov and Naimark, 1977; Fujita et al., 1990; Grachev, 1973, 2000; Mokshanzev et al., 1977; Parfenov et al., 1988; and others] and values of displacements also are not established with confidence. Such is the case for determination of the sign of strike-slip faults: sinistral or dextral [Imaev et al., 1990; Merzliakov, 1971]. The focal mechanisms are widely cited as an inderect evidence of the existence of active strike-slip fault. In this connection it is necessary to underline that the Moma rift itself is characterized by low seismic activity: only 12 events of a magnitude of 4.5 or greater were recorded during the time span of 1961-1996 (Figure 16) [Franke et al., 2000; Koz'min, 1984]. Focal depths are less than $15 \mathrm{~km}$ that is typical for continental rifts [Grachev, 1987]. The low level and diffuse character of seismicity of the Moma rift lead to conflicting focal mechanisms determinations [Cook et al., 1986; Franke et al., 2000; Fujita et al., 1990; Koz'min, 1984; Lasareva and Misharina, 1965]. The dominant mechanism of events is thrust faulting with compression axis perpendicular to the strike of the active faults and strike-slip component has been established only for earthquakes outside of the Moma rift (Artyk event of May 18, 1971). Thus, there are 

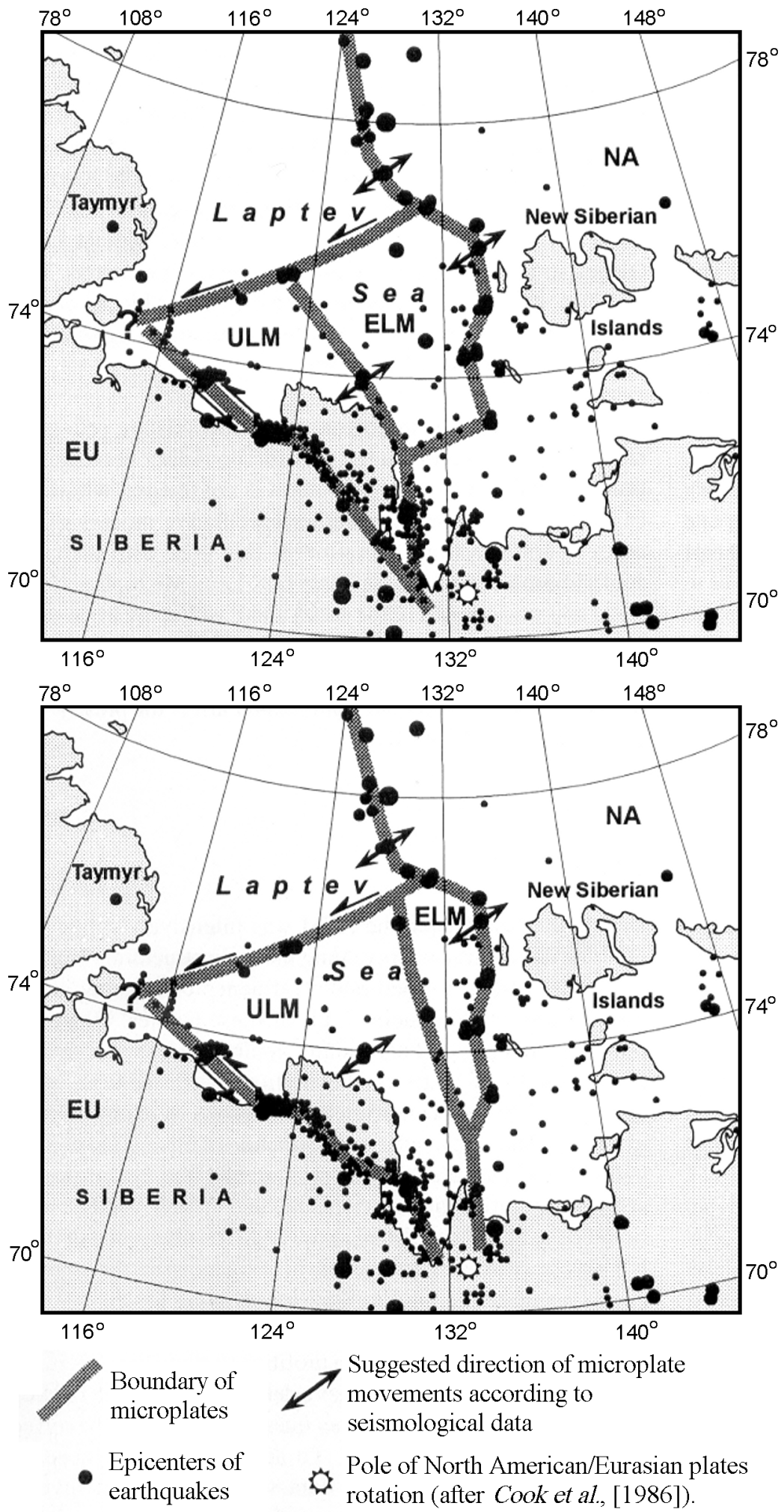

Figure 12. Two possible models of plate kinematics in the Laptev Sea [Avetisov, 1993]. EA - Eurasian plate, NA - North American plate, ULM and ELM are Ust' Lena and East Laptev microplates correspondingly. 


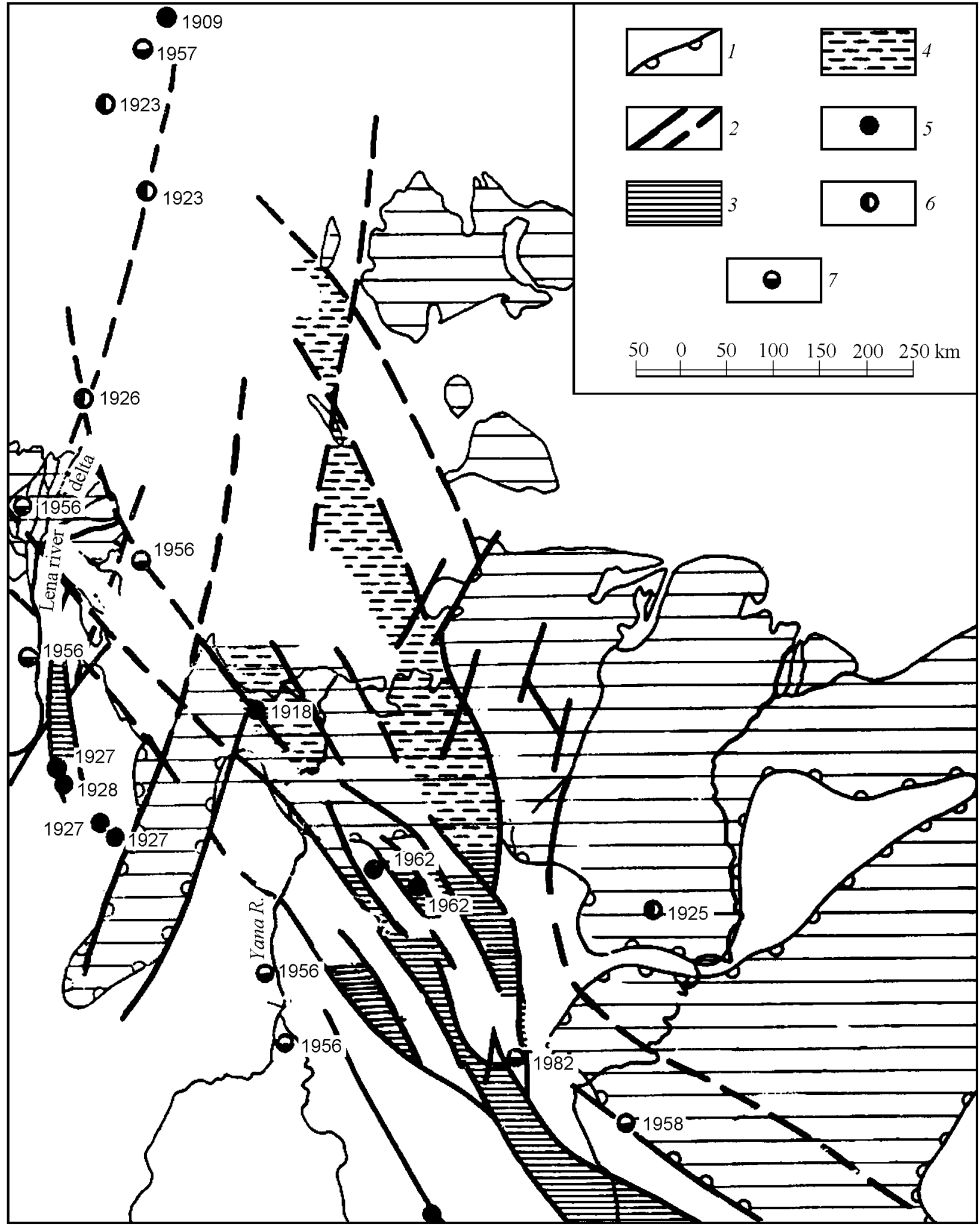

Figure 13. Junction of the eastern branch of earthquakes on the Laptev Sea with the West-Poluosny fault system [after Patyk-Kara and Grishin, 1972 from Grachev, 1982]. 1 - Primorian and Kolyma lowlands; 2 - faults manifested during the recent tectonic stage; 3 - grabens; 4 - submerged blocks within Primorian lowland and shelf; 5 - earthquakes epicenters and the year of event: $5-\mathrm{M}=6 ; 6-\mathrm{M}=5$ to $6 ; 7-\mathrm{M}=4-5$. 


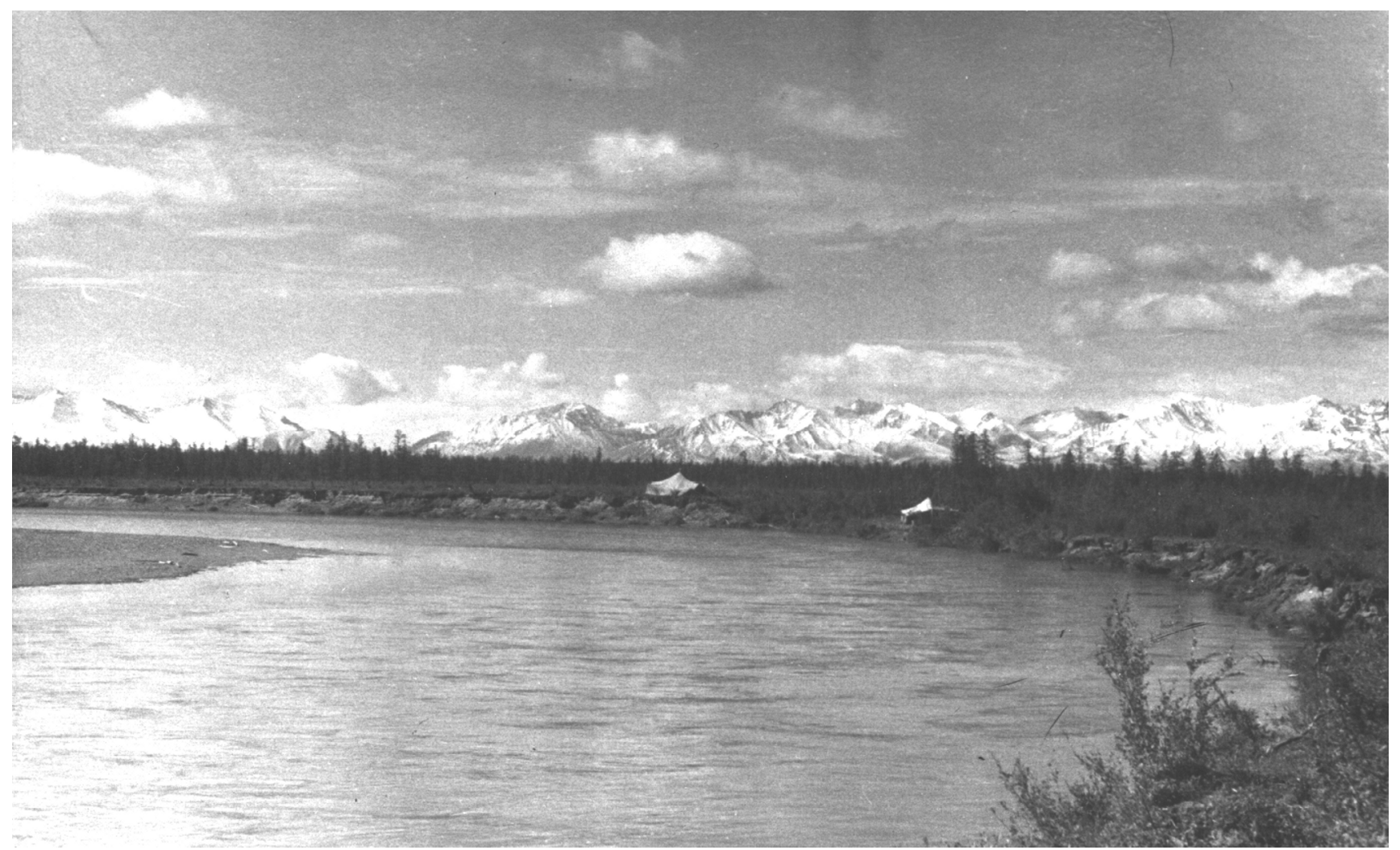

Figure 14. Normal fault separates the Ulakhan-Chistyai Ridge (Chersky mountain system) (background) from the Moma trough (the Moma river is in a foreground).

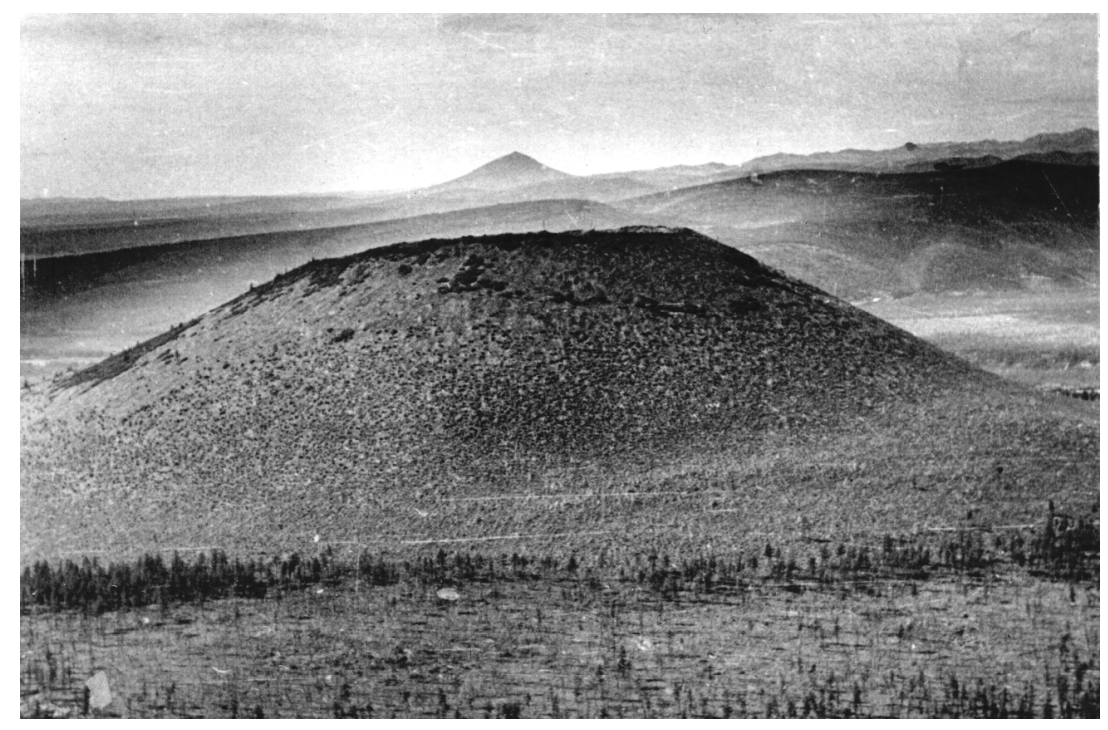

Figure 15. Transition zone from the Moma Ridge to the Moma trough in the vicinity of the Balagan-Tas volcano. On the background one can see the Uraga-Haya liparite dome. 


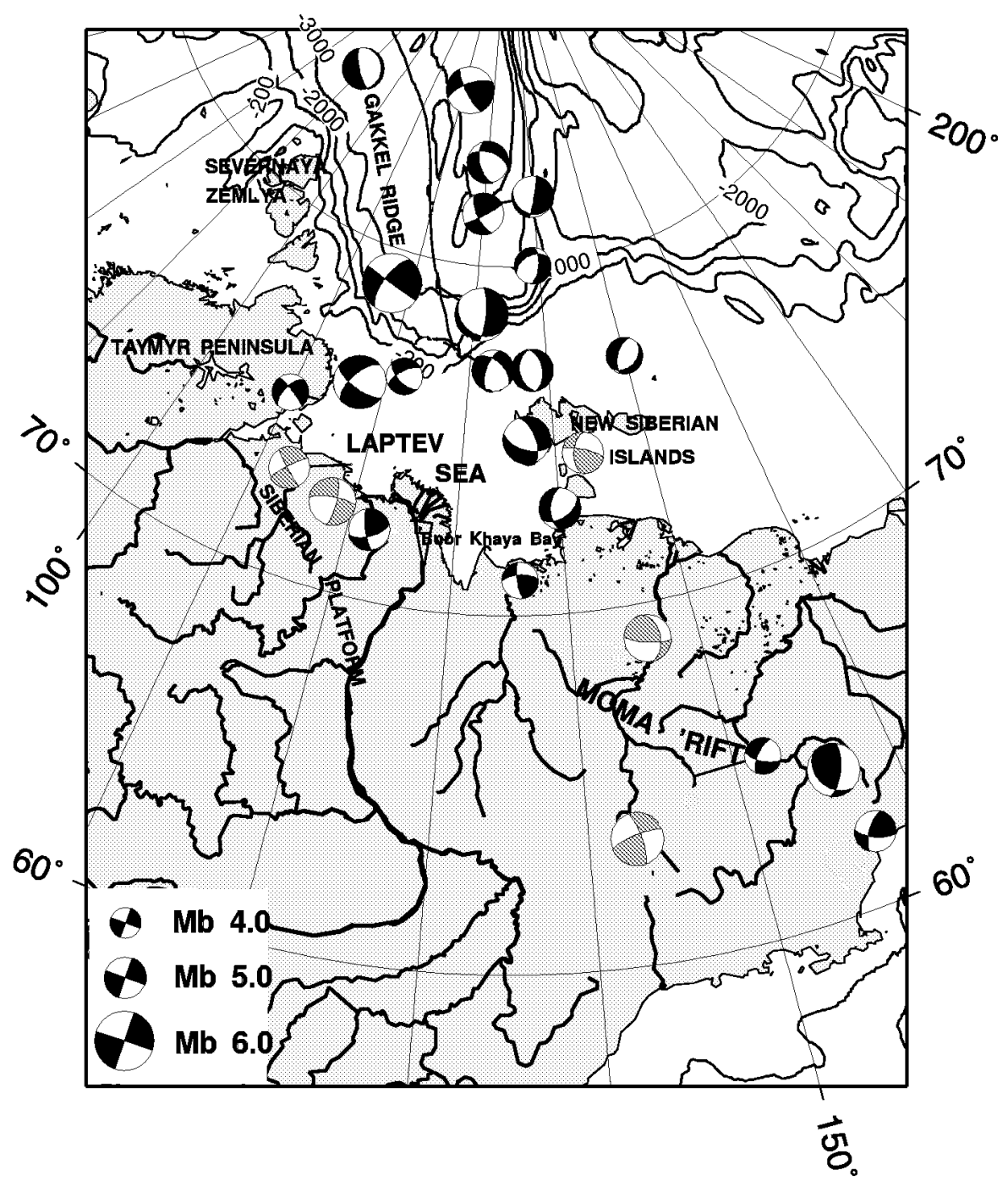

Figure 16. Focal mechanisms of the Arctic Rift System for the time span 1976-1996 in magnitude proportional scale [Franke et al., 2000]. Solutions with gray quadrants were calculated using additional to the broadband data ISC catalog first motions.

no geological and seismological data suggesting the existence of the active strike-slip faults in the Moma rift. It does not mean indeed that there are no shear zones within the Moma rift at all. Such faults will most likely be present but their existence must be a subject of an additional study.

The first data on the active low angle faults along the western and eastern margin of the Verkhoyansk-Kolyma mountains have the great importance for understanding the recent geodynamics. Such faults were described on the boundary the Verkhoyansk folded belt and the Siberian platform [Parfenov and Prokop'ev, 1993] and along the northeastern part of the Moma ridge in junction with the Zyrianka basin [Gaiduk et al., 1988]. Because the planes of thrusts dip in opposite directions from the Verkhoyansk-Kolyma mountains there are two probable explanation. The first one assumes that the extension exists within the internal part of mountains and the second one proposes that they are the result of the gravity sliding (charriage cassant of E. Argaund). However the latter explanation is less likely for the lack of the high topography.

In conclusion we would like to pay attention to the new data on heat flow [Drachev et al., 2003]. New measurements allow to prove the high heat-flow near the Moma Rift (70$78 \mathrm{~mW} / \mathrm{m}^{2}$ ) that is considerably higher than is known for adjacent part of the Siberian platform $\left(20-25 \mathrm{~mW} / \mathrm{m}^{2}\right)$ (Figure 17). These data along with the well known hot springs and young Balagan-Tas volcano in the Moma rift [Grachev, 1973, 1982] indicate that the upper mantle beneath this area is abnormally heated. Therefore we have all signs suggesting the recent activity here and this is in contradiction with the idea that rifting process was aborted in Pliocene [Fujita et al., 1990]. 


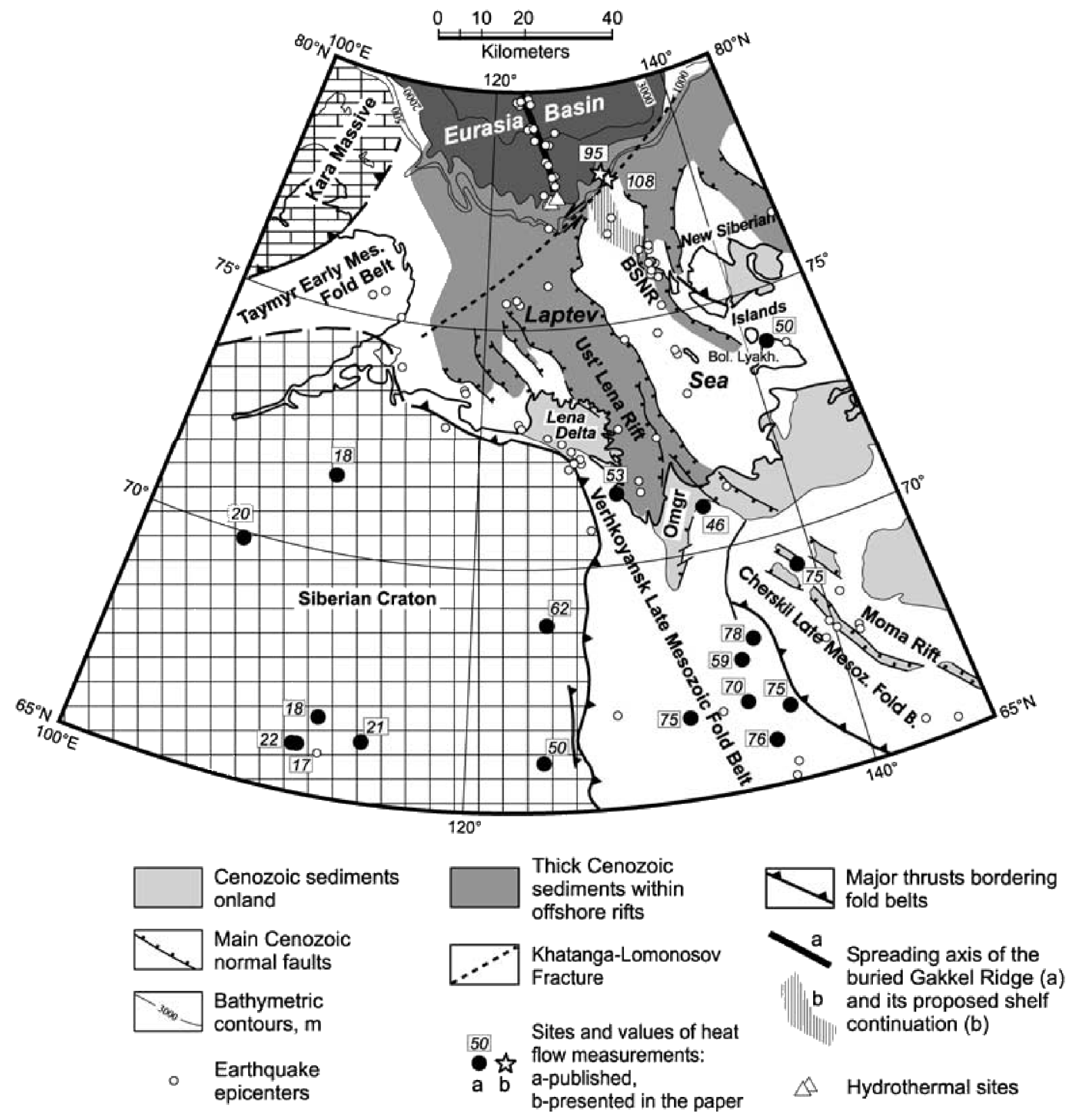

Figure 17. Heat flow values of the Arctic Rift System [Drachev et al., 2003]. BSNR-Bel'kov-Svyatoi Nos Rift, Omgr-Omoloi Graben.

Recent Volcanism of the Moma Rift and the Adjacent Part of the North-Eastern Asia

Since the 1930s, several features of basaltic volcanism have been successively discovered at the northeastern margin of the Eurasian continent. First, the Balagan-Tas Volcano (Figure 18, 19) was discovered by V. A. Zimin in 1939 in the left-hand bank area of the Moma River, Cherskii Range [Vas'kovskii, 1949]. In 1952, I. F. Legkii found a young volcano named Anyui (sometimes also called the Ustiev Volcano) in the right-hand bank area of the Bol'shoi Anyui River, Monni River valley (Figure 20). In 1957, several young volcanic features named the Aluchin volcanoes were recognized by G. K. Kleshchev $100 \mathrm{~km}$ south of the Anyui Volcano, in the Aluchin River valley.

One more volcano, named the Bilibin Volcano after the noted geologist Yu. A. Bilibin, was discovered by 


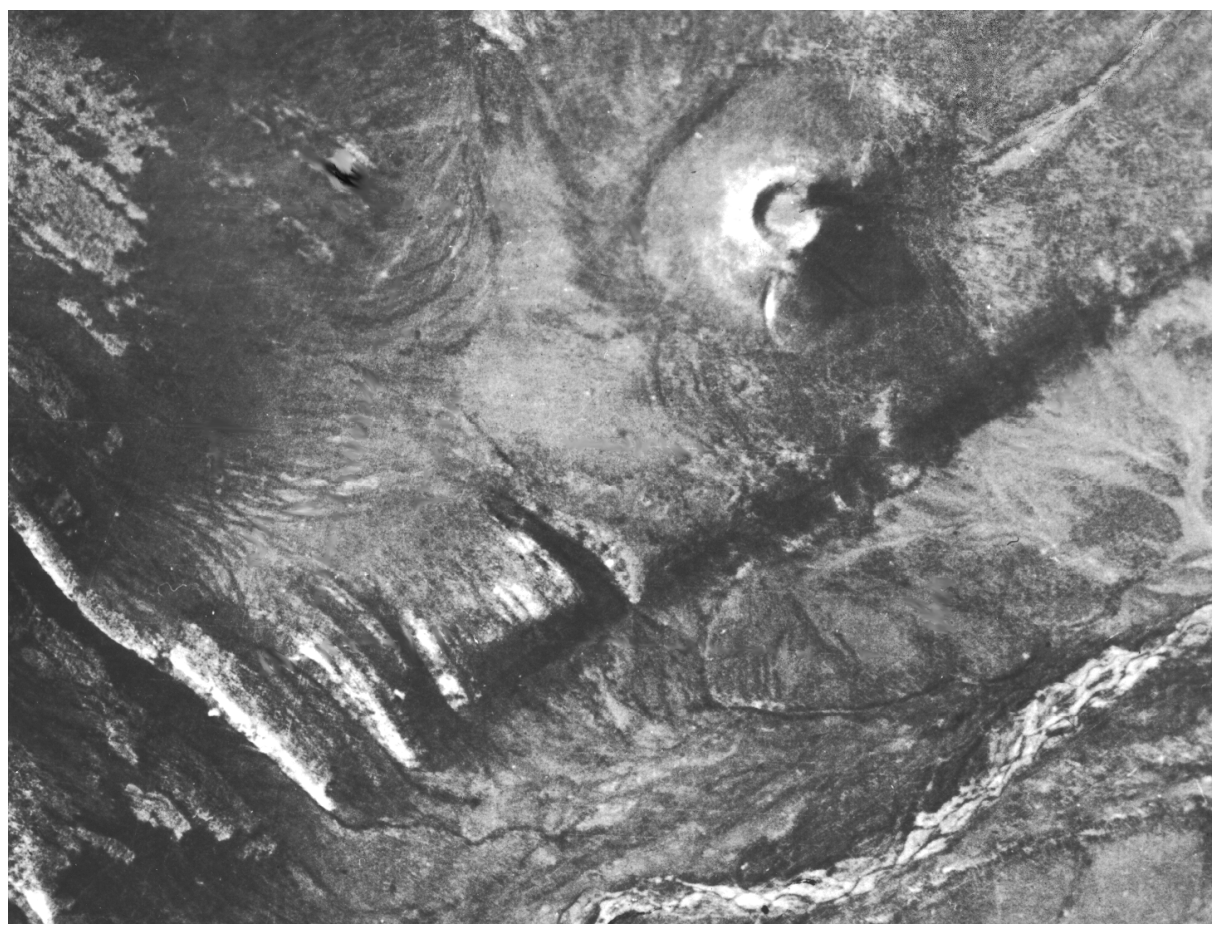

Figure 18. Balagan-Tas volcano (aerophoto). One can see the young fault line divided the lava flows of the upper and low levels.

Yu. M. Dovgal' in the same year in the left-hand bank area of the Bol'shoi Anyui River [Chasovitin, 1963]. Ichetovkin et al. [1970] report alkalic basaltoid exposures in the VerkhneKupkinskii and Nerkinskii depression filled with Neogene deposits. Basaltic dikes intrude Upper Cretaceous rhyolites and are overlain by Upper Quaternary glacial deposits; therefore, these basalts are likely to date at the Quaternary, although recent $\mathrm{K}-\mathrm{Ar}$ isotope datings of volcanics in the Viliga River basin yielded an age of 11 to $13 \mathrm{Ma}[$ Apt et al., 1997]. These estimates, as well as ${ }^{40} \mathrm{Ar} /{ }^{36} \mathrm{Ar}$ age determinations, should be regarded with caution because of the presence of excess argon. The young age of basalts, developed in the De Longa island group (Zhokhov and Vil'kitskii Islands) and dated previously at the Cretaceous [Geology..., 1970], has been established with certainty only recently, in the mid-1980s [Bogdanovskiiet et al., 1992]. Similar to the Priokhot'e basalts, K-Ar datings raise doubts because they indicate a radiometric age ranging from 0.4 to $6.1 \mathrm{Ma}$, which contradicts a very fresh habit of the rocks and absence of any data on interruption in volcanic activity [Geology..., 1970; Savostin et al., 1988]. It is also surprising that datings of limburgites from the Vil'kitskii Island yield ages ranging from 0.4 to $0.9 \mathrm{Ma}$, whereas the age range of the same rocks from the neighboring Zhokhov Island is 1.9 to $4.2 \mathrm{Ma}$. Thus, the problem of lava ages in the De-Longa archipelago remains open.

The morphology and age of these volcanoes, as well as the main petrographic characteristics of extrusive lavas, are described in detail elsewhere [Bazarova and Vavilov, 1989; Bogdanovskii et al., 1993; Dovgal' and Chasovitin, 1965; Grachev, 1973; Grachev et al., 1991, 1996, 1998a, 1998b; Rudich, 1964; Silant'ev et al., 1991; Ustiev, 1961]. None of the volcanic features, except for basalts of the Zhokhov and Vil'kitskii Volcanoes, are older than the Holocene [Rudich and Ustiev, 1966; Ustiev, 1961]. In several cases such as the Anyui and Balagan-Tas Volcanoes, eruptions are established to occur in the historical time [Grachev, 1973; Ustiev, 1961]. As regards the rhyolitic Uraga-Khaya dome in the right-hand bank area of the Moma River, $30 \mathrm{~km}$ northeast of the Balagan-Tas Volcano, its age is estimated at the Middle Miocene (16.2 $\pm 0.4 \mathrm{Ma}$ according to $\mathrm{K}-\mathrm{Ar}$ determinations on biotite) [Grachev, 1973], although this structure was previously considered as a Quaternary volcanic feature.

Thus, nearly synchronous fissure eruptions of lavas similar (though not identical) in composition occurred over the vast territory of the Mesozoic fold belt in Northeast Asia (Figure 21) and may have resulted in the formation of scoria and lava cones; this phenomenon has not been explained up to now. However, such phenomena are not exceptional and are known in other regions of Asia (northern and northeastern China, Mongolia, Vietnam, Cambodia) and North Africa (Hoggar, Tibesti Mountains), which differ essentially from Northeast Asia in their geologic history. Hence, it is natural to suppose that such geologic processes have the same origin. The most recent geochemical and isotopic data provide a key to the solution of this problem. 


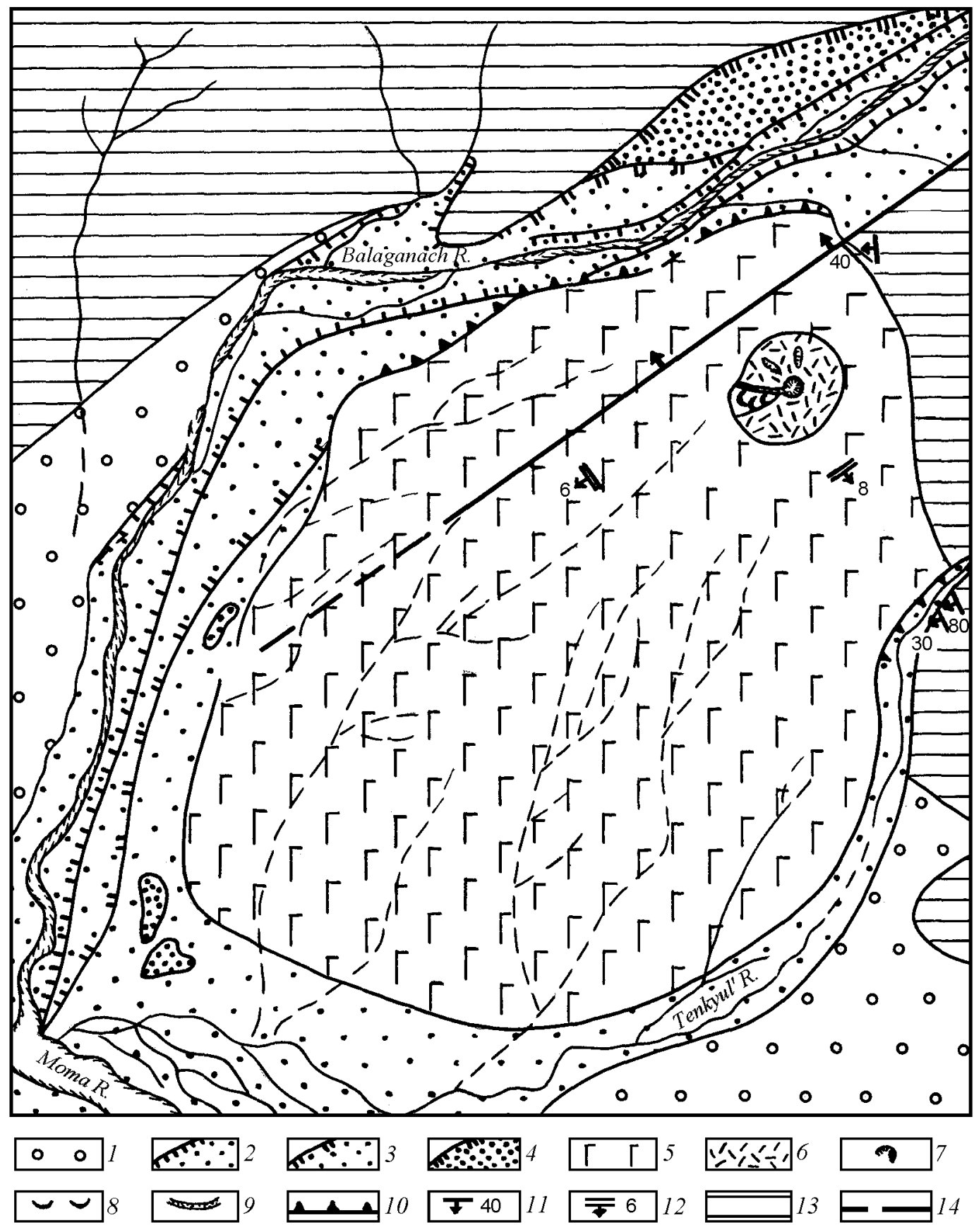

Figure 19. Geological scheme of the Balagan-Tas volcano [Grachev, 2000]. 1-4-alluvial sediments of the river terraces and their breaks; 5 - basalts of the fissure eruption stage; 6 - scoria cone; 7 - crater of volcano; 8 - outlines of the lava flow on the slope of volcano; 9 - barancoes on the volcano slopes; 10 - scarp of the lava flow; 11 - dipping of the Jurassic rocks; 12 - dipping of the lava flows; 13 - Jurassic rocks; 14 - fault.

The Chemical Composition of Basalts

Data on the modal composition of Holocene volcanic lavas reported by many authors [Bazarova and Vavilov, 1989; Dovgal' and Chasovitin, 1965; Grachev, 1973; Rudich, 1964;
Savostin et al., 1988; Ustiev, 1961] provide poor constraints on the origin of magmatic activity. For this reason, I focus on specific features of the distribution of major, minor, and rare earth elements based mostly on new data. All of the studied volcanic rocks are subdivided into two series depending on their petrochemical characteristics. 
These are alkalic and subalkalic series, with the majority of figurative points lying in the field of the alkalic series (Figure 22; Tables 1 and 2). Using the wellknown discriminant diagrams [Macdonald and Katsura, 1964; Saggerson and Williams, 1964], one readily concludes that most figurative points of lava compositions from the Balagan-Tas Volcano and volcanoes of the Zhokhov Island and Priokhot'e region lie in the strongly alkaline field, whereas those of the Anyui and Bilibin Volcanoes lie near the boundary between the mid- and subalkalic series (Figure 22). Although findings of spinel lherzolite xenoliths in lavas of the Zhokhov Island and Priokhot'e region are reported in the literature [Apt et al., 1997; Bogdanovskii et al., 1993], this does not rule out the possible presence of similar xenoliths in other centers of young volcanism in Northeast Asia because xenoliths are usually present in the pipe or, less frequently, pyroclastic facies, and their occurrence in lava flow facies rocks is scarcely probable due to virtually lacking erosion and the fissure nature of eruptions.

This conclusion is supported by long-term experience in the study of ultrabasic xenoliths in basalts of the Baikal rift, China, Tien Shan, Spain, the Canary Islands, and other regions. The chemistry is generally characterized by a high bulk concentration of $\mathrm{FeO}^{*}$ nearly independent of the $\mathrm{MgO}$ concentration, which varies from 6 to $20 \%$, and a typically high alkalinity of the rocks (4 to $7.5 \%$ ). Also characteristic is a higher phosphorus concentration (0.3 to 1.0\%). All of the basalts, except those of the Anyui Volcano, have a high Ti concentration exceeding $2 \%$. Maximum $\mathrm{TiO}_{2}$ concentrations reach 3.81 and $4.79 \%$ in the Balagan-Tas and Priokhot'e lavas, respectively. Thus, the major petrochemical characteristic of all the studied basalts in question is their high Ti, Fe, and $\mathrm{P}$ concentrations, and they may be assigned to the Fe-Ti type [Grachev, 1987, 1998b]. Comparison of their average compositions with those of the known continental and mantle plumes (Table 3) shows that they are identical in these characteristics.

As it is easily seen from Figure 2, a clear inverse correlation exists between the $\mathrm{Si}$ and alkali concentrations, related to $K$ variations. Such a tendency is well expressed in

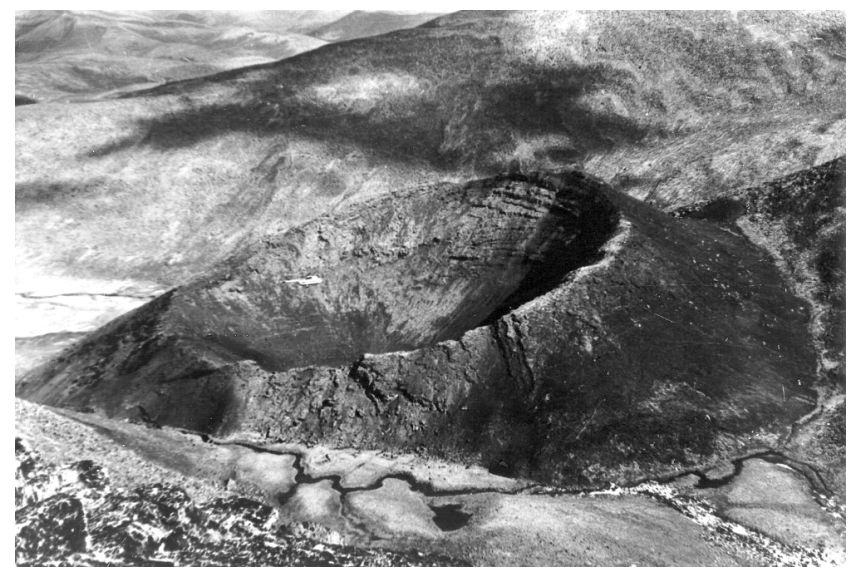

Figure 20. Anui volcano (photograph of Skalatsky A. and Gorodinsky M.).

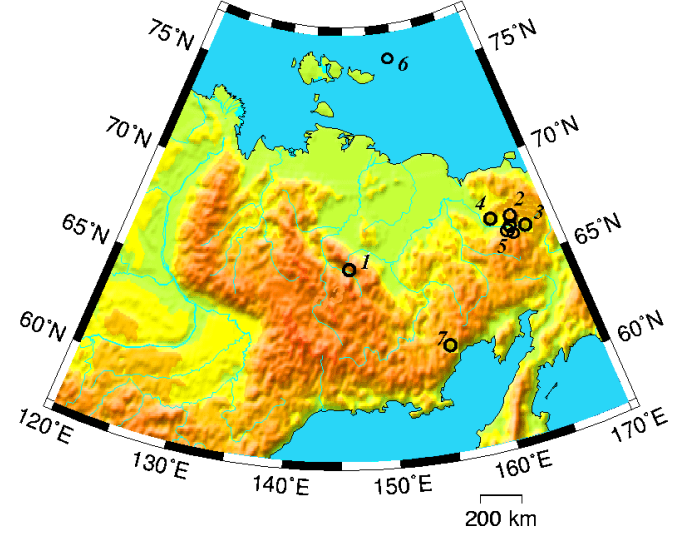

Figure 21. Schematic map showing the position of Quaternary volcanoes in Northeast Asia: (1) Balagan-Tas Volcano; (2) Anyui Volcano; (3) Bilibin Volcano; (4) Pyatistennyi Volcano; (5) Aluchin volcanoes; (6) Zhokhov Island; (7) Viliga River basalts.

Zhokhov and Priokhot'e volcanics and is virtually absent in basalts of the Balagan-Tas, Anyui, and Aluchin volcanoes. Regularities in lava composition variations are considered below in terms of the CIPW classification (Table 2). As is evident from Figure 23, all of the volcanic rocks may be sub-

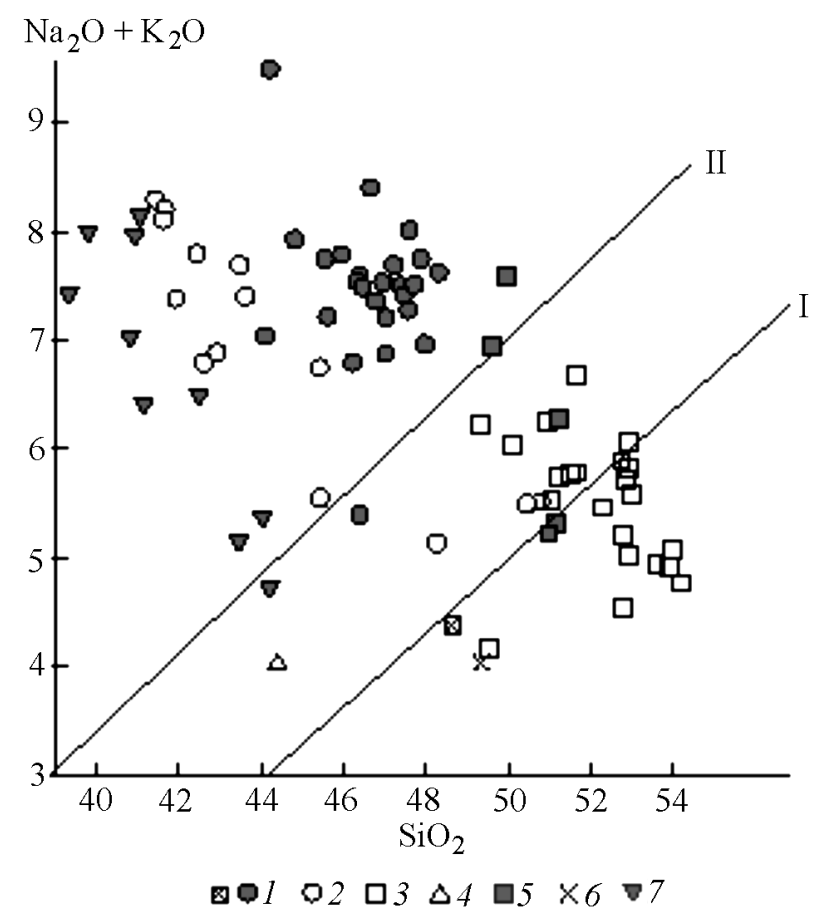

Figure 22. Silica-alkali diagram for compositions of the volcanic rocks studied: (1) Balagan-Tas Volcano; (2) Zhokhov Island; (3) Anyui Volcano; (4) Pyatistennyi Volcano; (5) Aluchin volcanoes; (6) Bilibin Volcano; (7) Priokhot'e. The dividing lines: I, Macdonald and Katsura [1964]; II, Saggerson and Williams [1964]. 
Table 1. Representative chemical compositions (wt\%) and concentrations of rare and rare earth elements (g/t) in Quaternary lavas of Northeast Asia volcanoes

\begin{tabular}{|c|c|c|c|c|c|c|c|c|c|}
\hline Sample & 1 & 2 & 3 & 4 & 5 & 6 & 7 & 8 & 9 \\
\hline & BT-1 & BT-2 & BT-3 & BT-4 & BT-5 & BT-6 & J-1 & $\mathrm{J}-2$ & $\mathrm{~J}-3$ \\
\hline $\mathrm{SiO}_{2}$ & 47.59 & 47.73 & 44.11 & 47.17 & 47.85 & 48.30 & 43.62 & 45.16 & 44.94 \\
\hline $\mathrm{TiO}_{2}$ & 2.16 & 2.30 & 2.32 & 2.35 & 2.24 & 2.12 & 2.00 & 2.23 & 2.00 \\
\hline $\mathrm{Al}_{2} \mathrm{O}_{3}$ & 14.68 & 15.08 & 14.37 & 14.55 & 15.59 & 15.92 & 12.48 & 13.59 & 11.96 \\
\hline $\mathrm{FeO}^{*}$ & 9.13 & 9.37 & 9.42 & 9.18 & 9.40 & 8.24 & 10.11 & 10.47 & 9.32 \\
\hline $\mathrm{MnO}$ & 0.11 & 0.12 & 0.12 & 0.13 & 0.12 & 0.11 & 0.13 & 0.14 & 0.13 \\
\hline $\mathrm{MgO}$ & 7.36 & 7.03 & 8.41 & 8.31 & 7.69 & 7.57 & 13.48 & 10.36 & 14.25 \\
\hline $\mathrm{CaO}$ & 7.92 & 7.76 & 8.97 & 8.41 & 7.73 & 7.08 & 7.68 & 8.30 & 7.41 \\
\hline $\mathrm{Na}_{2} \mathrm{O}$ & 5.57 & 4.90 & 4.74 & 5.20 & 5.35 & 5.30 & 4.57 & 5.33 & 4.52 \\
\hline $\mathrm{K}_{2} \mathrm{O}$ & 2.45 & 2.62 & 2.31 & 2.50 & 2.41 & 2.34 & 2.41 & 2.36 & 2.24 \\
\hline $\mathrm{P}_{2} \mathrm{O}_{5}$ & 1.40 & 0.92 & 1.51 & 1.05 & 1.00 & 1.08 & 0.72 & 0.77 & 0.63 \\
\hline Total & 98.37 & 97.83 & 96.28 & 98.85 & 99.38 & 98.06 & 97.20 & 98.71 & 97.40 \\
\hline $\mathrm{H}_{2} \mathrm{O}$ & - & - & - & - & - & - & - & - & - \\
\hline LOI & 2.00 & 4.36 & 2.20 & 1.24 & 1.08 & 1.14 & 1.56 & 0.48 & 1.54 \\
\hline $\mathrm{Mg} \#$ & 58.96 & 57.20 & 61.40 & 61.72 & 59.32 & 62.07 & 70.38 & 63.82 & 73.15 \\
\hline $\mathrm{Cr}$ & 174 & 169 & 172 & 151 & 164 & 164 & 606 & 324 & 581 \\
\hline $\mathrm{Co}$ & 41 & 45 & 42 & 43 & 44 & 42 & 58 & 54 & 64 \\
\hline $\mathrm{Sc}$ & 14 & 15 & 14 & 15 & 15 & 14 & 16 & 17 & 17 \\
\hline $\mathrm{Pb}$ & 5 & - & - & - & - & - & - & - & - \\
\hline K & 20338 & 21749 & 19176 & 20753 & 20006 & 19425 & 20006 & 19591 & 18595 \\
\hline $\mathrm{Rb}$ & 23 & 21 & 25 & 24 & 22 & 23 & 23 & 25 & 24 \\
\hline Cs & - & - & - & - & - & - & - & - & - \\
\hline $\mathrm{Ba}$ & 1234 & - & - & 960 & 964 & 1020 & - & - & 577 \\
\hline $\mathrm{Sr}$ & 2400 & 1723 & 2202 & 1857 & 1781 & 1797 & 936 & 1057 & 968 \\
\hline $\mathrm{Ta}$ & 1.40 & 1.40 & - & - & 1.70 & 1.60 & 2.80 & 3.70 & 3.70 \\
\hline $\mathrm{Nb}$ & - & 1.4 & 1.4 & 1.5 & - & - & - & - & - \\
\hline Hf & 4.10 & - & 4.00 & 4.20 & 4.60 & 4.40 & 3.40 & 4.30 & 4.50 \\
\hline $\mathrm{Zr}$ & 263 & - & - & 253 & 244 & 254 & - & - & 232 \\
\hline $\mathrm{Ti}$ & 12949 & 13789 & 13908 & 14088 & 13429 & 12709 & 11990 & 13369 & 11990 \\
\hline $\mathrm{Y}$ & 20 & - & - & 18 & 14 & 13 & - & - & 12 \\
\hline Th & 2.90 & 3.20 & 3.30 & 3.80 & 3.60 & 3.00 & 2.80 & 3.70 & 4.20 \\
\hline $\mathrm{U}$ & 1.80 & 2.20 & 2.10 & - & 1.10 & - & 1.10 & 1.30 & 1.90 \\
\hline $\mathrm{La}$ & 50.00 & 41.00 & 56.00 & 39.00 & 41.00 & 37.00 & - & 33.00 & 31.00 \\
\hline $\mathrm{Ce}$ & 83.00 & 71.00 & 90.00 & 71.00 & 86.00 & 64.00 & 54.00 & 58.00 & 45.00 \\
\hline $\mathrm{Nd}$ & 62.53 & 53.72 & 67.70 & 55.98 & 52.51 & 55.14 & 38.18 & 38.18 & 41.82 \\
\hline $\mathrm{Sm}$ & 11.25 & 10.29 & 11.95 & 10.58 & 10.07 & 10.48 & 8.55 & 8.56 & 9.43 \\
\hline $\mathrm{Eu}$ & 3.10 & 3.00 & 3.20 & 2.80 & 3.10 & 2.90 & 2.20 & 2.60 & 2.40 \\
\hline $\mathrm{Tb}$ & 0.95 & 1.00 & 0.94 & 1.10 & 1.10 & 1.10 & 0.90 & 0.88 & 0.90 \\
\hline $\mathrm{Yb}$ & 1.30 & 1.70 & 1.70 & 1.80 & 2.10 & 1.20 & 1.50 & 1.40 & 1.60 \\
\hline $\mathrm{Lu}$ & 0.19 & 0.24 & 0.18 & 0.15 & 0.22 & 0.19 & 0.17 & 0.19 & 0.20 \\
\hline$(\mathrm{La} / \mathrm{Sm})_{\mathrm{N}}$ & 2.59 & 2.33 & 2.74 & 2.15 & 1.51 & 2.06 & 1.98 & 2.61 & 2.48 \\
\hline$(\mathrm{Ce} / \mathrm{Yb})_{\mathrm{N}}$ & 15.61 & 10.21 & 12.95 & 9.65 & 10.02 & 13.04 & 8.80 & 10.13 & 6.88 \\
\hline $\mathrm{La} / \mathrm{Ce}$ & 0.60 & 0.58 & 0.62 & 0.55 & 0.48 & 0.58 & 0.54 & 0.57 & 0.69 \\
\hline $\mathrm{Sr} / \mathrm{Nd}$ & 38.4 & 32.1 & 32.5 & 33.2 & 33.9 & 32.6 & 24.5 & 27.3 & 23.1 \\
\hline
\end{tabular}


Table 1. Continued

\begin{tabular}{|c|c|c|c|c|c|c|c|c|c|c|}
\hline Sample & 10 & 11 & 12 & 13 & 14 & 15 & 16 & 17 & 18 & 19 \\
\hline & $\mathrm{U}-125 / 18$ & $\mathrm{U}-125 / 12$ & U-122/8 & U-120/5 & U-120/15 & U-120/8 & A-105/1 & A- $48 / 1$ & A-110/8 & $545 / 2$ \\
\hline $\mathrm{SiO}_{2}$ & 51.68 & 52.73 & 52.92 & 52.80 & 50.97 & 52.90 & 49.96 & 51.19 & 49.58 & 44.41 \\
\hline $\mathrm{TiO}_{2}$ & 1.86 & 1.58 & 1.50 & 1.70 & 1.46 & 1.88 & 1.89 & 1.92 & 1.97 & 0.92 \\
\hline $\mathrm{Al}_{2} \mathrm{O}_{3}$ & 15.73 & 15.75 & 16.00 & 15.92 & 15.89 & 15.87 & 15.83 & 14.73 & 15.54 & 12.74 \\
\hline $\mathrm{FeO}^{*}$ & 9.16 & 7.39 & 9.31 & 6.95 & 8.97 & 9.42 & 8.53 & 8.84 & 10.20 & 9.04 \\
\hline $\mathrm{MnO}$ & 0.11 & 0.09 & 0.10 & 0.08 & 0.11 & 6.21 & 0.11 & 0.12 & 0.12 & 0.16 \\
\hline $\mathrm{MgO}$ & 6.00 & 6.83 & 5.93 & 5.67 & 6.63 & 7.26 & 7.24 & 6.88 & 6.98 & 8.95 \\
\hline $\mathrm{CaO}$ & 7.38 & 6.92 & 7.08 & 6.95 & 7.58 & 7.58 & 6.87 & 7.30 & 7.03 & 13.99 \\
\hline $\mathrm{Na}_{2} \mathrm{O}$ & 4.85 & 4.81 & 4.77 & 4.42 & 4.64 & 4.90 & 5.36 & 1.89 & 4.84 & 2.75 \\
\hline $\mathrm{K}_{2} \mathrm{O}$ & 1.83 & 1.09 & 1.31 & 0.79 & 1.63 & 0.93 & 2.24 & 0.43 & 2.13 & 1.32 \\
\hline $\mathrm{P}_{2} \mathrm{O}_{5}$ & 0.47 & 0.50 & 0.37 & 0.40 & 0.40 & 0.44 & 0.59 & - & 0.54 & 0.76 \\
\hline Total & 99.07 & 97.69 & 99.29 & 95.68 & 98.28 & 107.39 & 98.62 & 93.30 & 98.93 & 95.04 \\
\hline $\mathrm{H}_{2} \mathrm{O}$ & 0.36 & - & 0.30 & - & 1.18 & - & - & - & 0.46 & - \\
\hline LOI & 0.54 & 1.98 & 0.22 & 2.52 & 1.18 & 0.28 & 1.00 & 1.50 & 0.80 & 4.20 \\
\hline $\mathrm{Mg} \#$ & 53.87 & 62.23 & 53.17 & 59.26 & 56.84 & 57.88 & 60.21 & 58.09 & 54.94 & 63.81 \\
\hline $\mathrm{Cr}$ & 168 & - & 162 & 171 & - & - & 174 & 692 & 625 & 213 \\
\hline $\mathrm{Co}$ & 36 & - & 38 & 39 & - & - & 41 & 119 & 84 & 39 \\
\hline $\mathrm{Sc}$ & 16 & - & 15 & 16 & - & - & 16 & 16 & 22 & 43 \\
\hline $\mathrm{Pb}$ & - & - & - & - & - & - & - & - & - & - \\
\hline $\mathrm{K}$ & 15191 & 9048 & 10875 & 6558 & 13531 & 7720 & 18595 & 3570 & 17682 & 10958 \\
\hline $\mathrm{Rb}$ & 15 & - & 11 & 9 & - & - & 18 & 15 & 18 & 56 \\
\hline Cs & - & - & - & - & - & - & - & - & - & 1.70 \\
\hline $\mathrm{Ba}$ & - & - & - & - & - & - & - & - & - & - \\
\hline $\mathrm{Sr}$ & 528 & - & 465 & 464 & - & - & 632 & 513 & 636 & 848 \\
\hline $\mathrm{Ta}$ & 1.80 & - & 1.50 & 1.40 & - & - & 2.40 & 2.00 & 2.40 & 0.36 \\
\hline $\mathrm{Nb}$ & - & - & - & - & - & - & - & - & - & - \\
\hline Hf & 3.30 & - & 2.50 & 2.60 & - & - & 4.00 & 3.70 & 4.20 & 2.50 \\
\hline $\mathrm{Zr}$ & - & - & - & - & - & - & - & - & - & - \\
\hline $\mathrm{Ti}$ & 11151 & 9472 & 8993 & 10192 & 8753 & 11271 & 11331 & 11510 & 11810 & 5515 \\
\hline $\mathrm{Y}$ & - & - & - & - & - & - & - & - & - & - \\
\hline Th & 2.40 & - & 2.20 & 2.50 & - & - & 2.90 & 2.10 & 3.70 & 2.70 \\
\hline $\mathrm{U}$ & 0.80 & - & - & 1.10 & - & - & 1.30 & 1.20 & 0.80 & 2.00 \\
\hline $\mathrm{La}$ & 16.00 & - & 13.00 & 12.00 & - & - & 22.00 & 17.00 & 21.00 & 23.00 \\
\hline $\mathrm{Ce}$ & 33.00 & - & 27.00 & 21.00 & - & - & 41.00 & 39.00 & 43.00 & 44.00 \\
\hline $\mathrm{Nd}$ & 23.03 & - & 19.60 & 18.38 & - & - & 29.38 & 23.88 & 29.44 & 21.00 \\
\hline $\mathrm{Sm}$ & 6.09 & - & 5.58 & 5.38 & - & - & 7.32 & 6.24 & 7.32 & 7.30 \\
\hline $\mathrm{Eu}$ & 1.90 & - & 1.80 & 1.90 & - & - & 2.20 & 2.00 & 2.10 & 2.20 \\
\hline $\mathrm{Tb}$ & 0.81 & - & 0.81 & 0.82 & - & - & 1.30 & 0.77 & 0.87 & 0.87 \\
\hline $\mathrm{Yb}$ & 1.30 & - & 0.92 & 1.30 & - & - & 1.50 & 1.80 & 1.40 & 2.20 \\
\hline $\mathrm{Lu}$ & 0.20 & - & 0.10 & 0.18 & - & - & 0.18 & 0.20 & 0.25 & 0.36 \\
\hline$(\mathrm{La} / \mathrm{Sm})_{\mathrm{N}}$ & 2.28 & - & 1.62 & 1.37 & - & - & 2.25 & 1.91 & 2.08 & 1.75 \\
\hline$(\mathrm{Ce} / \mathrm{Yb})_{\mathrm{N}}$ & 6.21 & - & 7.18 & 3.95 & - & - & 6.68 & 5.30 & 7.51 & 4.89 \\
\hline $\mathrm{La} / \mathrm{Ce}$ & 0.48 & - & 0.48 & 0.57 & - & - & 0.54 & 0.44 & 0.49 & 0.52 \\
\hline $\mathrm{Sr} / \mathrm{Nd}$ & 22.9 & - & 23.7 & 25.2 & - & - & 21.5 & 21.5 & 21.6 & 26.2 \\
\hline
\end{tabular}

Note: The analyses were performed in the Experimental Expedition, Sevzapgeologiya PGO, St. Petersburg by the X-ray fluorescence and neutron activation methods with the use of domestic and international standards under guidance of N. B. Fillipov (analyst A. A. Kol'tsov). 1-6 - Balagan-Tas Volcano; 7-9 - Zhokhov Island; 10-15 - Anyui Volcano; 16-18 - Aluchin volcanoes; 19 Pyatistennyi Volcano. 
Table 2. Normative composition (\%), some petrochemical parameters, and factor values of Quaternary lavas from Northeast Asia volcanoes

\begin{tabular}{|c|c|c|c|c|c|c|c|c|c|c|}
\hline Sample & BT1 & BT2 & BT3 & BT4 & BT5 & BT6 & $\mathrm{J}-1$ & $\mathrm{~J}-2$ & $\mathrm{~J}-3$ & $\mathrm{U} 125 / 18$ \\
\hline Or & 14.48 & 15.48 & 13.65 & 14.77 & 14.24 & 13.83 & 14.24 & 13.95 & 13.24 & 10.81 \\
\hline $\mathrm{Ab}$ & 22.96 & 21.58 & 14.82 & 17.07 & 21.21 & 26.26 & 5.90 & 10.12 & 11.43 & 38.06 \\
\hline An & 7.82 & 11.42 & 11.11 & 8.98 & 11.41 & 12.74 & 6.42 & 6.19 & 5.73 & 15.75 \\
\hline $\mathrm{Ne}$ & 13.10 & 10.77 & 13.70 & 14.59 & 13.03 & 10.07 & 17.75 & 18.95 & 14.53 & 1.61 \\
\hline Di & 17.70 & 16.97 & 18.54 & 20.64 & 16.30 & 12.18 & 21.34 & 23.73 & 21.10 & 14.15 \\
\hline $\mathrm{Ol}$ & 9.58 & 10.75 & 10.52 & 11.66 & 12.11 & 12.21 & 20.66 & 13.67 & 19.77 & 8.35 \\
\hline Fo & 7.92 & 7.96 & 9.25 & 9.05 & 9.19 & 9.88 & 17.47 & 11.42 & 18.40 & 6.65 \\
\hline $\mathrm{Fa}$ & 1.66 & 2.80 & 1.27 & 2.61 & 2.92 & 2.33 & 3.19 & 2.25 & 1.37 & 1.70 \\
\hline Mt & 5.80 & 4.71 & 6.48 & 4.57 & 4.83 & 4.57 & 5.81 & 6.54 & 6.81 & 6.13 \\
\hline Il & 4.10 & 4.37 & 4.41 & 4.46 & 4.25 & 4.03 & 3.80 & 4.24 & 3.80 & 3.53 \\
\hline Ap & 3.32 & 2.13 & 3.58 & 2.49 & 2.37 & 2.56 & 1.71 & 1.82 & 1.49 & 1.11 \\
\hline D.I. & 50.53 & 47.83 & 42.17 & 46.43 & 48.49 & 50.16 & 37.90 & 43.02 & 39.19 & 50.49 \\
\hline Col.I. & 37.18 & 36.81 & 39.95 & 41.32 & 37.50 & 32.89 & 51.61 & 48.17 & 51.49 & 31.17 \\
\hline $\mathrm{Pl}_{\text {norm }}$ & 14.86 & 22.41 & 22.79 & 17.82 & 20.99 & 22.84 & 15.32 & 12.92 & 13.85 & 27.87 \\
\hline $\mathrm{F} 1$ & -2.00 & -1.63 & -1.09 & -1.22 & -1.77 & -2.12 & 0.40 & -0.82 & 0.22 & -2.26 \\
\hline $\mathrm{F} 2$ & -1.41 & -1.18 & -2.52 & -1.55 & -1.09 & -0.76 & -3.24 & -2.65 & -3.11 & 0.44 \\
\hline F3 & -0.98 & -1.43 & 0.01 & -1.19 & -1.64 & -1.50 & 0.81 & -0.18 & 1.65 & -1.08 \\
\hline Sample & U125/12 & $\mathrm{U} 122 / 8$ & $\mathrm{U} 120 / 5$ & U120/15 & $\mathrm{U} 120 / 8$ & A105/1 & A48/1 & A110/8 & $545 / 2$ & \\
\hline $\mathrm{Q}$ & - & - & 3.07 & - & - & - & 11.28 & - & - & \\
\hline Or & 6.44 & 7.74 & 4.67 & 9.63 & 5.50 & 13.24 & 2.54 & 12.59 & 7.80 & \\
\hline $\mathrm{Ab}$ & 40.70 & 40.36 & 37.40 & 35.25 & 41.46 & 29.55 & 15.99 & 30.96 & 6.00 & \\
\hline An & 18.17 & 18.38 & 21.27 & 17.72 & 18.56 & 12.52 & 30.44 & 14.39 & 18.52 & \\
\hline $\mathrm{Ne}$ & - & - & - & 2.17 & - & 8.56 & - & 5.41 & 9.36 & \\
\hline Hy & 10.05 & 5.60 & 12.50 & - & 9.07 & - & 20.66 & - & - & \\
\hline Di & 10.18 & 11.59 & 8.38 & 13.88 & 11.61 & 14.07 & 4.63 & 13.50 & 36.81 & \\
\hline $\mathrm{Ol}$ & 3.22 & 7.70 & - & 11.48 & 3.38 & 10.95 & - & 10.79 & 8.80 & \\
\hline Mt & 5.12 & 4.52 & 4.54 & 4.78 & 6.15 & 5.12 & 4.42 & 6.77 & 4.57 & \\
\hline Il & 3.00 & 2.85 & 3.23 & 2.77 & 3.57 & 3.59 & 3.65 & 3.74 & 1.75 & \\
\hline Ap & 1.18 & 0.88 & 0.95 & 0.95 & 1.04 & 1.40 & - & 1.28 & 1.80 & \\
\hline D.I. & 47.14 & 48.10 & 45.14 & 47.06 & 46.96 & 51.35 & 29.82 & 48.96 & 23.16 & \\
\hline Col.I. & 31.57 & 32.26 & 28.66 & 32.91 & 33.79 & 33.73 & 33.35 & 34.80 & 51.92 & \\
\hline $\mathrm{Pl}_{\text {norm }}$ & 30.86 & 31.29 & 36.25 & 31.31 & 30.92 & 22.22 & 65.56 & 26.46 & 46.17 & \\
\hline $\mathrm{F} 1$ & -2.02 & -1.75 & -1.95 & -1.60 & -1.98 & -2.32 & 0.31 & -2.09 & 2.15 & \\
\hline $\mathrm{F} 2$ & 1.14 & 1.37 & 1.39 & 0.75 & 0.92 & -0.19 & 0.85 & -0.52 & -0.82 & \\
\hline F3 & -0.75 & -1.73 & -0.88 & -1.21 & -1.22 & -1.40 & 0.18 & -0.96 & 1.84 & \\
\hline
\end{tabular}

Note: Sample numbers are the same as in Table 1.

divided into two groups: the first, consisting of nephelinites, includes the Zhokhov limburgite (with normative leucite and larnite) and Priokhot'e basalts (with normative nepheline exceeding 5\%), and the second includes alkali basalts and hawaiites of the Balagan-Tas, Anyui, Bilibin, and Aluchin volcanoes and, in part, of the Zhokhov Island, whose fields in Figure 23 overlap. Note that all of the studied rock groups include picritic basalts (Figure 23), and some of the Zhokhov and Priokhot'e basaltoids fall into the basaltic komatiite field in Jensen's classification diagram [Jensen, 1976].

Data from the Pyatistennyi Volcano are limited, but the single analysis (Table 1 ) yields $\mathrm{CaO} / \mathrm{Al}_{2} \mathrm{O}_{3}>1$ at $\mathrm{MgO}=8.95 \%$. The analysis of the variation diagrams in Figure 24 shows that the $\mathrm{Fe}$, Ti, and $\mathrm{Si}$ bulk concentrations are virtually independent of the $\mathrm{Mg}$ concentration, whereas correlated behavior of $\mathrm{MgO}, \mathrm{Al}_{2} \mathrm{O}_{3}$, and $\mathrm{CaO}$ is typical of Zhokhov volcanics, and an inverse correlation of $\mathrm{MgO}$ with $\mathrm{CaO}$ and $\mathrm{K}_{2} \mathrm{O}$ is established in lavas of the Balagan-Tas, Anyui, and Aluchin volcanoes. Along with the $\mathrm{MgO}-\mathrm{Al}_{2} \mathrm{O}_{3}-\mathrm{CaO}$ diagram (Figure 25), these data indicate that the observed variations in composition are due to the fractionation of olivine and pyroxene from the parent melt of picrite composition. Removal of olivine from such a melt commonly results in the formation of basalts rich in alumina [Yoder and Tilley, 1965]; such rocks are similar in composition to hawaiites developed in Hawaii and in the Brito-Arctic province.

Thus, fractionation of olivine was the main process responsible for the formation of the volcanic rock series on the Zhokhov Island, and fractionation of pyroxene controlled the 
development of basanites and alkali basalts of the BalaganTas, Anyui, and Aluchin volcanoes.

The classification based on the factor analysis method of principal components [Grachev, 1987, 1991] provides the most efficient means for comparing volcanic rock composition and defining their position in the series of standard samples of basalts from various geodynamic environments. Figure 26 presents fields of lava compositions from the study volcanoes in the axes of factors 1 and 2 along with typical compositions of mantle plumes of the North Atlantic, Hawaii, Reunion Island, and Afar Triangle. All lavas, except for those of the Aluchin volcanoes, are seen to lie within the field of figurative points characteristic of the above mantle plumes. Moreover, this diagram most clearly demonstrates distinctions between various lavas and primarily the fact that basalt compositions from the Balagan-Tas and Bilibin volcanoes form a group differing from Zhokhov and Pyatistennyi volcanics along the axis of factor 1 . Two subgroups correlating with limburgites and alkali basalts are formed by the latter along the axes of factors 1 and 2. The position of Aluchin lavas on the factor diagram is close to the figurative points of basaltic composition from the Khamar-Daban Range and North Tien Shan (Figure 26b).

All areas of Holocene volcanism lie within the field of mantle plume basalts, as is evident from the comparison of the fields of lava compositions from the Quaternary Northeast Asia volcanoes with typical compositions of mantle plumes on the general factor diagram constructed from 60000 silicate analyses of basalts from all geodynamic environments (Figure 26). The distribution of rare earth elements (REE) is illustrated in Figure 27. All of the volcanic rocks are typically enriched in light REE and exhibit a fairly smooth trend, surprisingly similar to the REE distribution in basalts of the Khamar-Daban volcanic area [Grachev, 1998b] and other mantle plumes (see the inset in Figure 27). Our data do not support the presence of the Eu anomaly in the Zhokhov basalts [Savostin et al., 1988].

Variations in the $(\mathrm{La} / \mathrm{Sm})_{\mathrm{N}}$ and $(\mathrm{Ce} / \mathrm{Yb})_{\mathrm{N}}$ from Quaternary lavas of Northeast Asia volcanoes (Table 1) lie within the limits characteristic of mantle plumes [Le Roex et al., 1983; Schilling et al., 1983]. A similar conclusion may be drawn from the spider diagram analysis (Figure 28). Thus, in spite of the observed differences in modal and normative compositions, all of the studied volcanic rocks are similar in their distributions of rare elements and REE, which differ from both tholeiitic and alkali basalts. It is known that such a trend is inherent in basalts of the transitional type [Schilling et al., 1983, 1992].

\section{$\mathrm{He}, \mathrm{Ar}, \mathrm{Sr}$, and Nd Isotope Systematics}

Here, I present new constraints on the $\mathrm{He}, \mathrm{Ar}, \mathrm{Sr}$, and $\mathrm{Ne}$ isotope systematics in all of the studied areas of Quaternary volcanism in Northeast Asia. He isotopes were studied on bulk samples, which always yield underestimated values as compared with data from olivine phenocrysts or megacrysts [Drubetskoi and Grachev, 1987; Grachev et al., 1992]. Since these minerals are present in rocks as microlites, the inferred

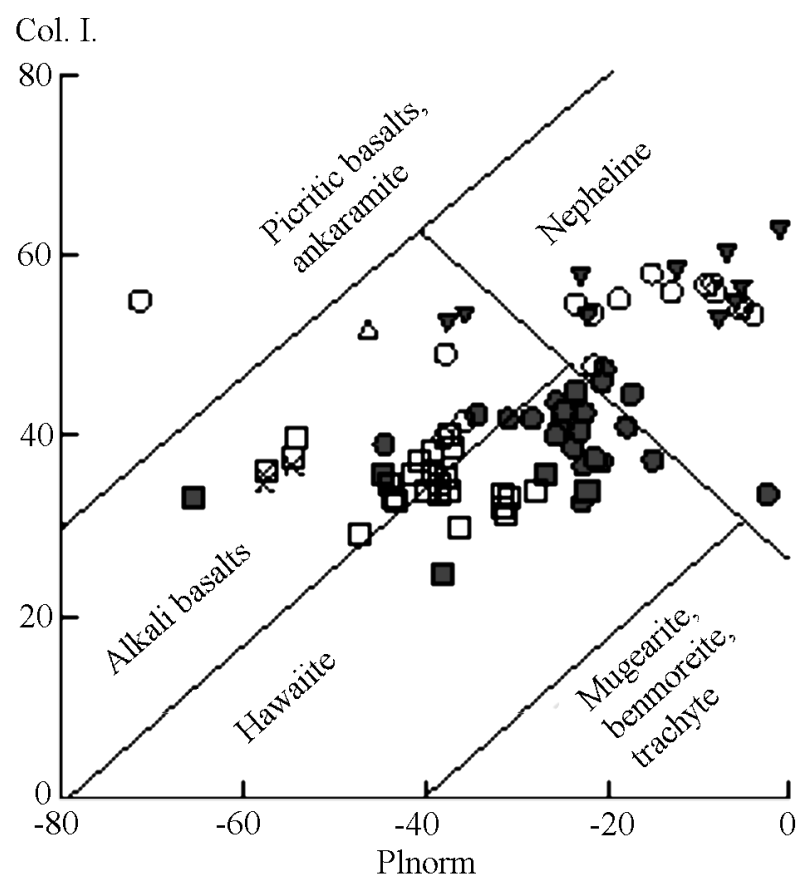

Figure 23. Normative plagioclase (Plnorm)-color index (Col. I.) for compositions of the volcanic rocks studied. The notation is the same as in Figure 22.

estimates of ${ }^{3} \mathrm{He} /{ }^{4} \mathrm{He}$ should be considered as a lower limit of this ratio.

Table 4 evidently indicates the ratio ${ }^{3} \mathrm{He} /{ }^{4} \mathrm{He}$ to range within wide limits: from ratios an order of magnitude greater than the atmospheric value $\left(1.39 \times 10^{-6}\right)$ to those typical of mantle plumes $\left(>20 \times 10^{-6}\right)$. Ratios close to or smaller than atmospheric values are observed in lavas of the Zhokhov Island and Pyatistennyi and Aluchin volcanoes. The BalaganTas Volcano basalts yield a ${ }^{3} \mathrm{He} /{ }^{4} \mathrm{He}$ value a few times greater than the atmospheric ratio, and the greatest values, close to the mantle plume ratios, are noted in lavas of the Anyui Volcano. Comparison of helium isotope ratios in Quaternary lavas of Northeast Asia volcanoes with areas of typical mantle plumes shows that they are also characterized by high variations in ${ }^{3} \mathrm{He} /{ }^{4} \mathrm{He}$, with deviations as large as an order of magnitude or more. The presence of samples with ${ }^{3} \mathrm{He} /{ }^{4} \mathrm{He}$ exceeding the typical value of mid-ocean ridge basalts (MORB) (in a sense, a constant) is evidence of a plume-type source.

The ${ }^{40} \mathrm{Ar} /{ }^{36} \mathrm{Ar}$ ratio in most of the studied samples is close to the atmospheric value (295.5), and deviations from this value are observed in Zhokhov and Pyatistennyi volcanics and in one sample from the Aluchin volcanoes. The analysis of the ${ }^{3} \mathrm{He} /{ }^{4} \mathrm{He}-{ }^{40} \mathrm{Ar} /{ }^{36} \mathrm{Ar}$ diagram (Figure 29) shows that the observed variations in $\mathrm{He}$ and Ar isotopes in most samples may be explained by the mixing effect of the atmosphere and a mantle plume. The fact that four samples do not comply with this regularity may be due to various factors. For the Pyatistennyi and Zhokhov lavas, the simplest explanation is their stronger degassing as compared with other rocks. On the other hand, these divergences may 


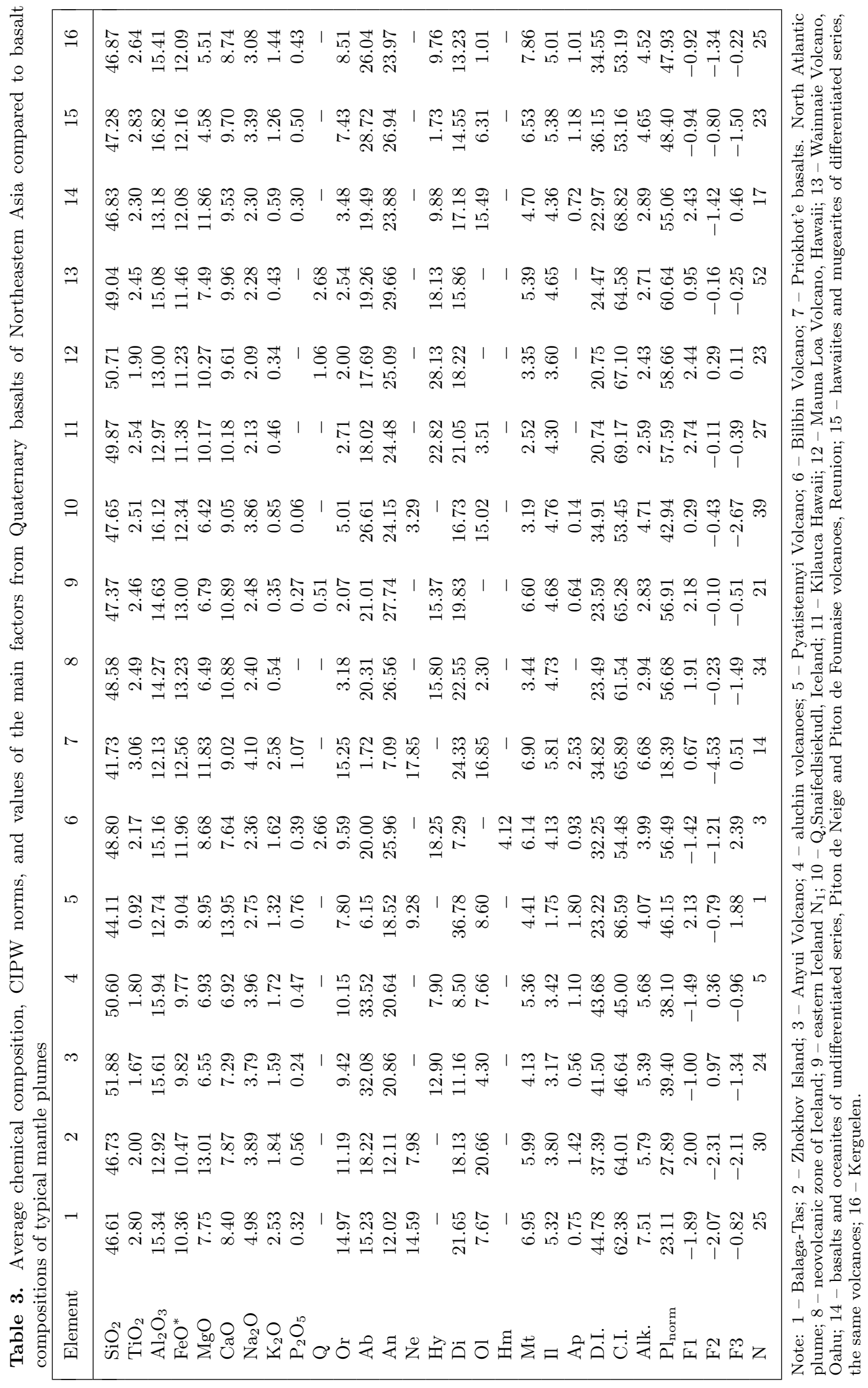



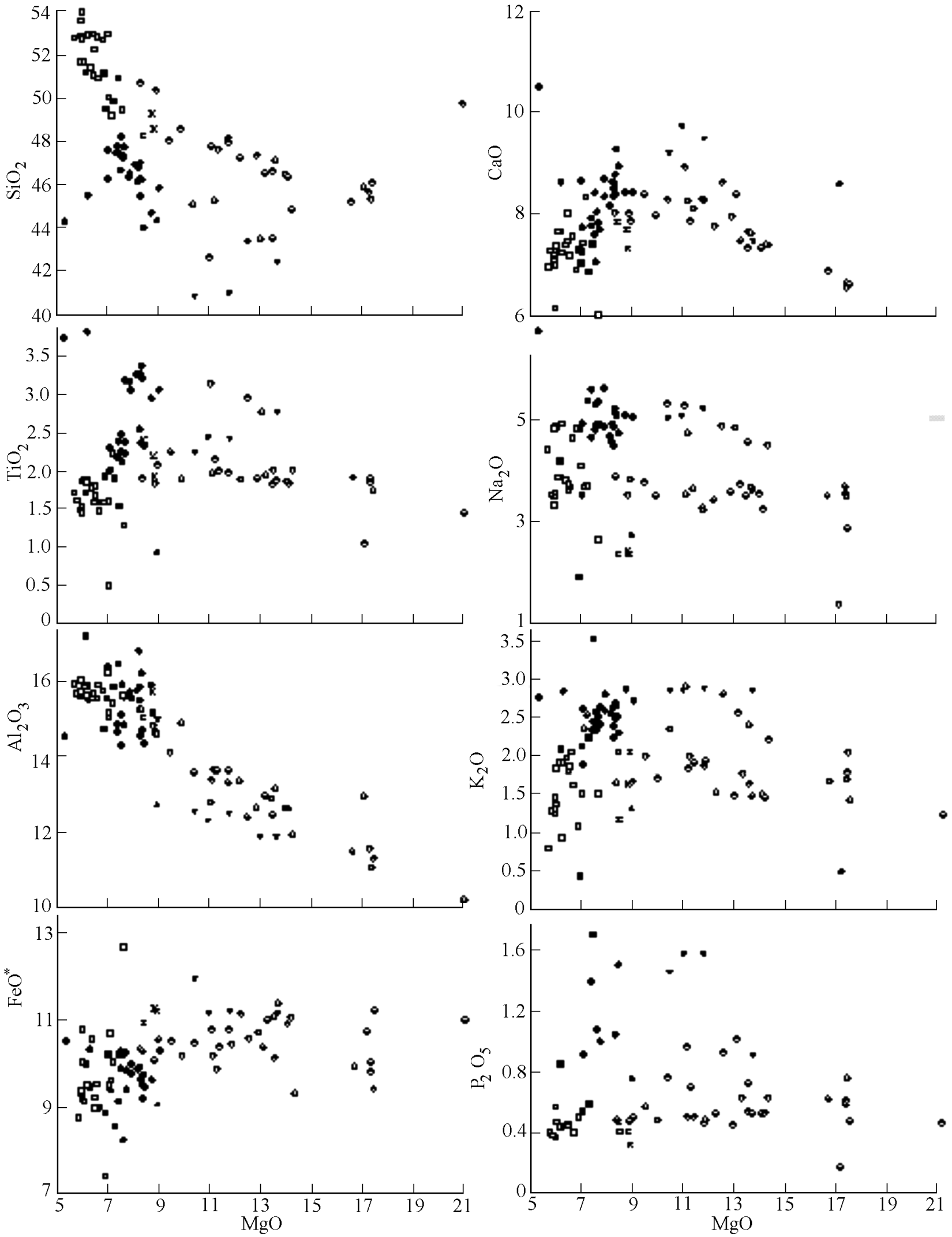

Figure 24. MgO-oxides diagram for compositions of the volcanic rocks studied. The notation is the same as in Figure 22. 


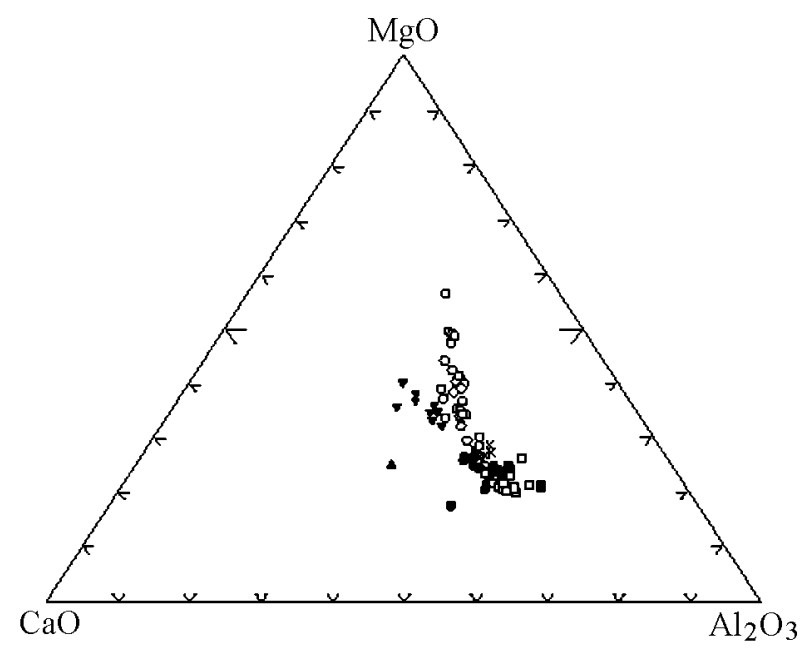

Figure 25. $\mathrm{Mg}-\mathrm{CaO}-\mathrm{Al}_{2} \mathrm{O}_{3}$ diagram for compositions of the volcanic rocks studied. The notation is the same as in Figure 22.

(a)
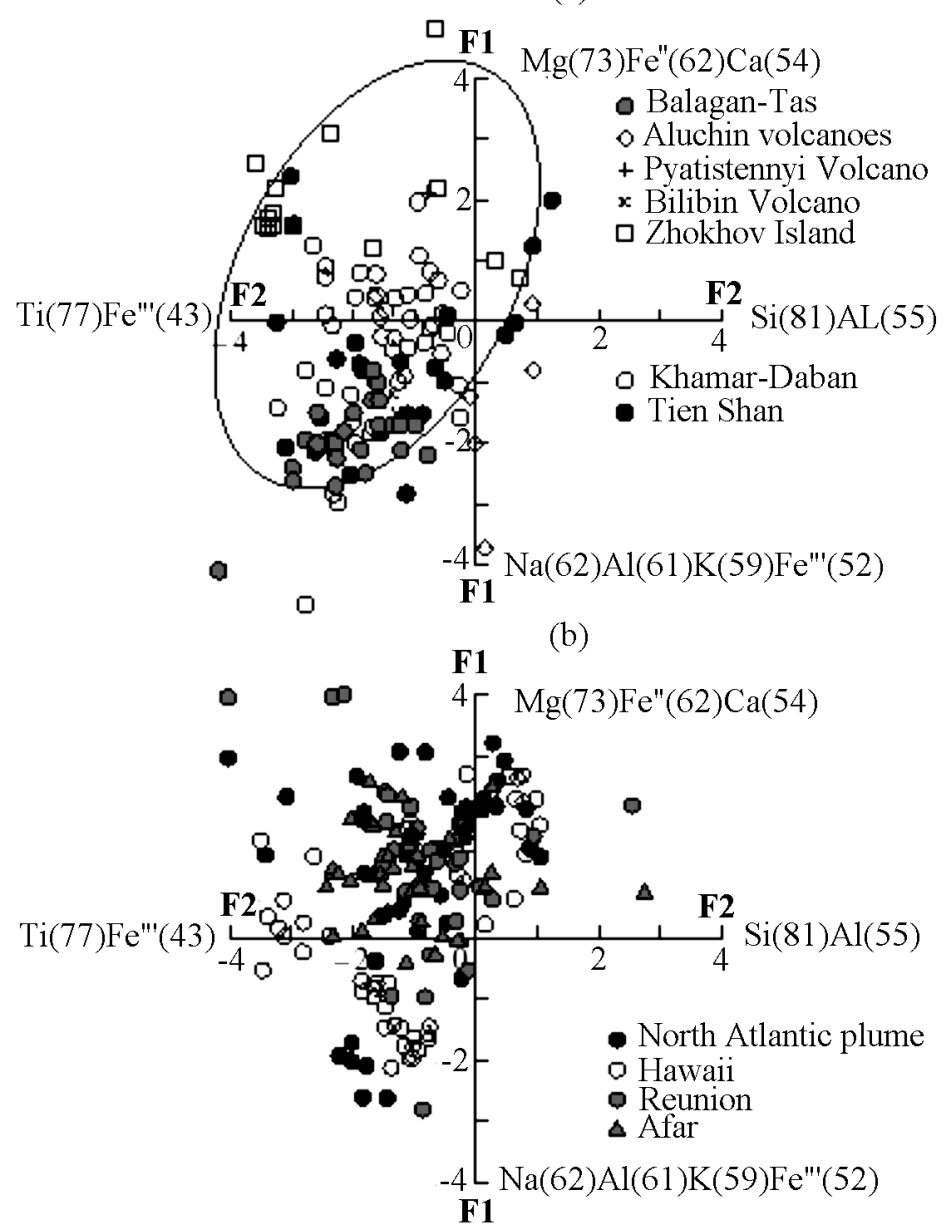

Figure 26. Factor diagram with axes of factors 1 and 2 (a) for Quaternary Northeast Asia basalts and (b) for basalts of typical mantle plumes. 

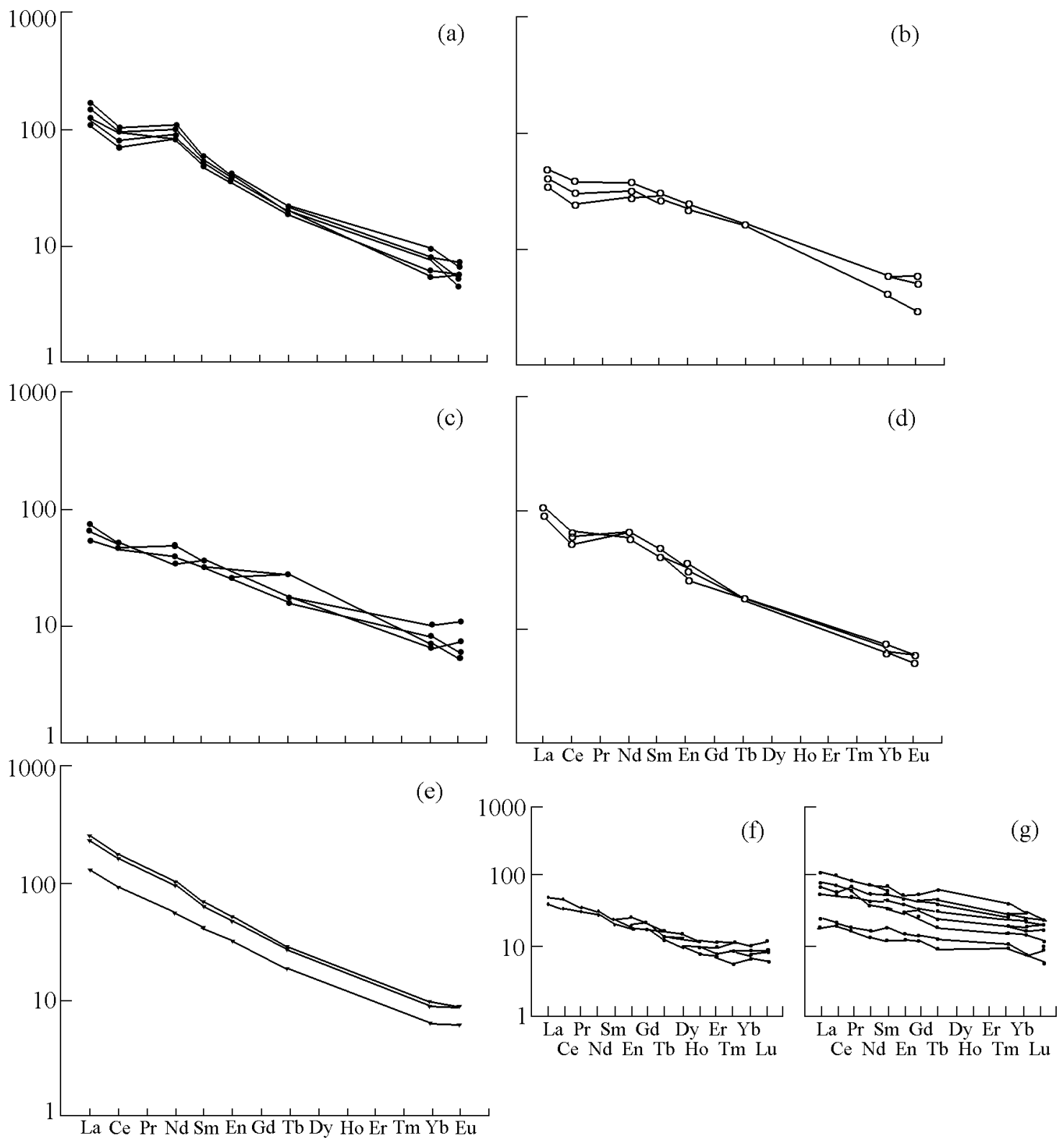

Figure 27. Distribution of rare earth elements normalized to chondrite after Sun [1982]: (a) BalaganTas Volcano; (b) Anyui Volcano; (c) Aluchin volcanoes; (d) Zhokhov Island volcanics; (e) Priokhot'e volcanics; (f) Iceland alkali basalts [Hards et al., 1995]; (g) Afar Triangle basalts [Schilling et al., 1992].

be due to the contamination of the primordial melt by the material of continental crust (the coordinates of the continental crust source are far beyond the diagram of Figure 29 in its right-hand bottom angle: ${ }^{3} \mathrm{He} /{ }^{4} \mathrm{He}=0.01 \times 10^{-6}$, ${ }^{40} \mathrm{Ar} /{ }^{36} \mathrm{Ar}>10000$ [Azbel' and Tolstikhin, 1988]).

$\mathrm{Sr}$ and $\mathrm{Nd}$ isotope ratios (Table 5 and Figure 30) show no considerable variations within the volcanic fields studied: all figurative points form compact groups on the ${ }^{87} \mathrm{Sr} /{ }^{86} \mathrm{Sr}-$ ${ }^{143} \mathrm{Nd} /{ }^{144} \mathrm{Nd}$ diagram and are, on the whole, consistent with the BSE-UM mantle array. Balagan-Tas, Aluchin, and Zhokhov lavas lie near the boundary between basalt composition fields of the MORB type and of such mantle plumes as the Afar Triangle and Hawaii; these lavas have a more depleted composition than lavas of the Anyui and Pyatistennyi volcanoes. Figurative points of the latter form a field completely consistent with mantle plume basalt compositions. Priokhot'e melanephelinites fall into the MORB field and are the most depleted of all the basalts studied. Thus, the observed $\mathrm{Sr}$ and $\mathrm{Nd}$ isotope variations are likely to be caused by the mixing of material from two sources: undepleted mantle and MORB. Lavas of the Anyui Volcano are distinguished by their high silica concentration reaching $54 \%$ (Figure 2) and being independent of the alkali content. In this respect, they resemble basalts of the Faeroes and Columbia River, 

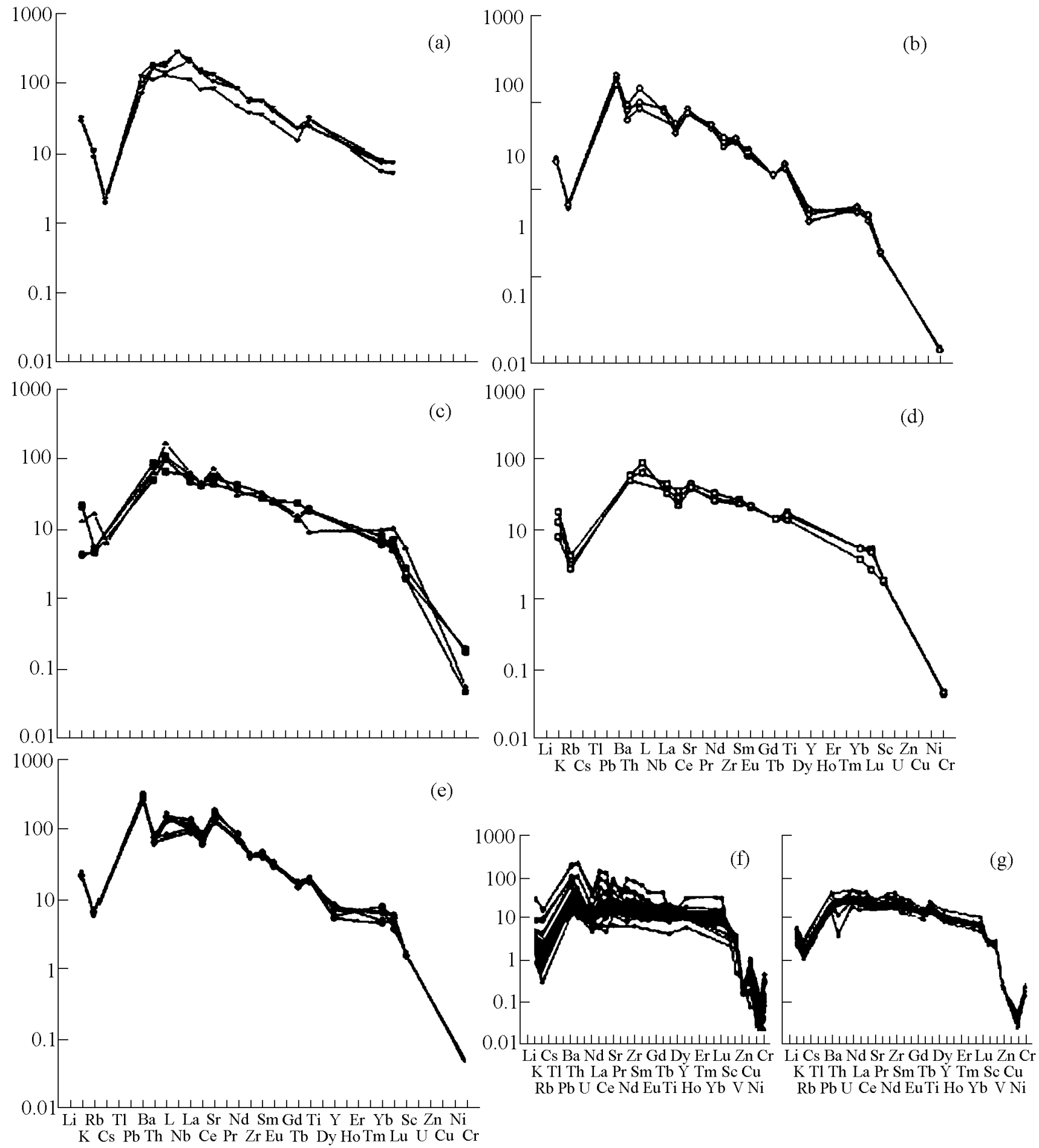

Figure 28. Spider-diagram of the minor element distribution, normalized to chondrite [Taylor and McLennan, 1985]: (a) Balagan-Tas Volcano; (b) Anyui Volcano; (c) Aluchin volcanoes; (d) Zhokhov Island volcanics; (e) Priokhot'e volcanics; (f) Paleocene northern Iceland basalts (North Atlantic plume) [Wallace et al., 1994]; (g) Mauna Kea, Hawaii basalts [Yang and Frey, 1994]. 
Table 4. Concentrations and isotope ration of He and Ar in lavas of Northeast Asia volcanoes

\begin{tabular}{|c|c|c|c|c|c|c|}
\hline No. & Sample & Weight, $\mathrm{g}$ & ${ }^{4} \mathrm{He}\left(10^{-6}\right), \mathrm{cm}^{3} / \mathrm{g}$ & ${ }^{3} \mathrm{He} /{ }^{4} \mathrm{He}\left(10^{-6}\right)$ & ${ }^{40} \operatorname{Ar}\left(10^{-6} \mathrm{~cm}^{3} / \mathrm{g}\right.$ & ${ }^{40} \mathrm{Ar} /{ }^{36} \mathrm{Ar}$ \\
\hline & \multicolumn{6}{|c|}{ Balagan-Tas Volcano } \\
\hline 1 & BT-1 & 0.7436 & 0.040 & $5.1 \pm 0.2$ & 0.59 & $316 \pm 4$ \\
\hline 2 & BT-2 & 0.7629 & 0.036 & $2.5 \pm 0.2$ & 0.56 & $312 \pm 4$ \\
\hline 3 & BT-3 & 0.7008 & 0.044 & $4.8 \pm 0.2$ & 0.34 & $305 \pm 3$ \\
\hline 4 & BT-4 & 0.6641 & 0.05 & $2.5 \pm 0.2$ & 0.63 & $304 \pm 1$ \\
\hline 5 & BT-5 & 0.7368 & 0.04 & $3.9 \pm 0.2$ & 0.31 & $305 \pm 1$ \\
\hline \multirow[t]{2}{*}{6} & BT-6 & 0.7580 & 0.05 & $3.8 \pm 0.3$ & 0.09 & $368 \pm 10$ \\
\hline & \multicolumn{6}{|c|}{ Anyui Volcano } \\
\hline 7 & $120 / 5$ & 0.5607 & 0.007 & $8.0 \pm 1.0$ & 0.28 & $286 \pm 6$ \\
\hline 8 & $122 / 8$ & 0.7377 & 0.008 & $18.0 \pm 2.0$ & 0.43 & $288 \pm 5$ \\
\hline \multirow[t]{2}{*}{9} & $125 / 18$ & 0.6889 & 0.008 & $7.2 \pm 0.5$ & 0.20 & $296 \pm 4$ \\
\hline & \multicolumn{6}{|c|}{ Aluchin volcanoes } \\
\hline 10 & $48 / 1$ & 0.7606 & 0.022 & $2.3 \pm 0.1$ & 0.16 & $365 \pm 7$ \\
\hline 11 & $105 / 1$ & 0.6341 & 0.023 & $1.8 \pm 0.1$ & 0.64 & $295 \pm 3$ \\
\hline \multirow[t]{2}{*}{12} & $110 / 8$ & 0.6936 & 0.017 & $0.15 \pm 0.06$ & 0.03 & $1900 \pm 300$ \\
\hline & \multicolumn{6}{|c|}{ Pyatistennyi Volcano } \\
\hline \multirow[t]{2}{*}{13} & $545 / 2$ & 0.8064 & 8.3 & $0.19 \pm 0.01$ & 9.5 & $1330 \pm 25$ \\
\hline & \multicolumn{6}{|c|}{ Zhokhov Island basalts } \\
\hline 14 & $\mathrm{~J}-1$ & 0.7620 & 0.22 & $0.56 \pm 0.05$ & 1.2 & $510 \pm 8$ \\
\hline 15 & $\mathrm{~J}-2$ & 0.7809 & 0.25 & $0.55 \pm 0.04$ & 0.60 & $528 \pm 8$ \\
\hline
\end{tabular}

Note: The analyses were performed on the MI-1201 mass spectrometer in the laboratory of isotope geochronology and geochemistry Geological Institute, Kola Research Center, Russian Academy of Sciences, Apatity, using a standard with its quality controlled by noble gases of the Earth's atmosphere. Samples were degassed through their complete melting in a Mo crucible with its temperature amounting to $1600^{\circ} \mathrm{C}$ (analyst I. L. Kamenskii). Three consecutive measurement runs were conducted on each sample, which allowed estimation of the analytical error. Blank meltings were perfomed before each analysis.

which are enriched in silica but markedly contaminated by radiogenic strontium. In the case considered, data on the $\mathrm{Sr}$ isotopes in Anyui lavas yield no evidence of the contamination, which is additionally supported by the joint analysis of $\mathrm{He}$ and $\mathrm{Sr}$ isotope ratios. In fact, ${ }^{3} \mathrm{He} /{ }^{4} \mathrm{He}-{ }^{87} \mathrm{Sr} /{ }^{86} \mathrm{Sr}$ (Figure 31 ) shows that variations in $\mathrm{He}$ isotopes are virtually

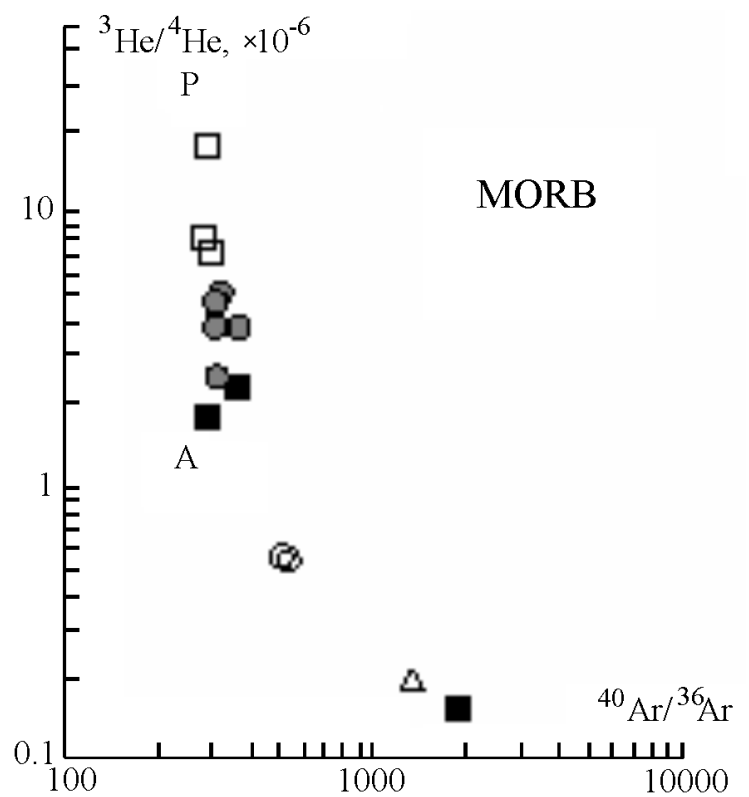

Figure 29. ${ }^{3} \mathrm{He} /{ }^{4} \mathrm{He}-{ }^{40} \mathrm{Ar} /{ }^{36} \mathrm{Ar}$ diagram for compositions of the volcanics studied: P, plume; A, atmosphere; MORB, mid-ocean ridge basalts. The rest of notation is the same as in Figure 22. independent of the $\mathrm{Sr}$ isotope composition. The same figure does not rule out the possible effect of contamination by the material of continental crust.

Most figurative points on the ${ }^{3} \mathrm{He} /{ }^{4} \mathrm{He}-{ }^{87} \mathrm{Sr} /{ }^{86} \mathrm{Sr}$ diagram (Figure 31) lie, on the one hand, in the field of mantle plume compositions from Iceland and Ethiopia and, on the other hand, from the Pacific continental margin. $\mathrm{He}$ isotope compositions from mature island arcs (Kamchatka, Japan, and others) and from the South American active continental margin are largely controlled by mixing with recycled oceanic crust [Poreda and Craig, 1989]. Therefore, the observed ${ }^{3} \mathrm{He} /{ }^{4} \mathrm{He}$ variations in lavas from the Anyui and Balagan-Tas Volcanoes and partly from the Aluchin volcanoes are due to the mixing of matter from three sources: MORB, mantle plumes, and recycled oceanic crust. The latter circumstance results from the history of Northeast Asia development in the Mesozoic [Parfenov, 1984].

\section{Discussion of Results}

A main feature of the Late Quaternary volcanism in Northeast Asia is the fact that lavas which simultaneously erupted over a vast territory in various recent geodynamic environments are similar in many whole rock geochemical and isotopic characteristics that are typical of intraplate magmatism areas regardless of the crust type. This fact alone implies that their volcanic evolution is related to neither the geologic history of the region studied nor the structural features of their recent geodynamics. 
Table 5. Sm-Nd and Rb-Sr isotope systematies in Quaternary lavas of Northeast Asia volcanoes

\begin{tabular}{|c|c|c|c|c|c|c|c|c|c|}
\hline No. & Sample & $\mathrm{Sm}^{*}$ & $\mathrm{Nd}^{*}$ & $\mathrm{Rb}^{*}$ & $\mathrm{Sr}^{*}$ & ${ }^{147} \mathrm{Sm} /{ }^{144} \mathrm{Nd}$ & ${ }^{143} \mathrm{Nd} /{ }^{144} \mathrm{Nd} \pm 2 \sigma$ & ${ }^{87} \mathrm{Rbr} /{ }^{86} \mathrm{Sr}$ & ${ }^{87} \mathrm{Sr} /{ }^{86} \mathrm{Sr} \pm 2 \sigma$ \\
\hline & \multicolumn{9}{|c|}{ Balagan-Tas Volcano } \\
\hline 1 & BT-1 & 11.25 & 62.53 & 22.52 & 2400.2 & 0.10878 & $0.512955 \pm 4$ & 0.02714 & $0.703322 \pm 13$ \\
\hline 2 & BT-2 & 10.29 & 53.72 & 21.48 & 1723.6 & 0.11581 & $0.512984 \pm 6$ & 0.03604 & $0.703349 \pm 15$ \\
\hline 3 & BT-3 & 11.95 & 52.51 & 22.21 & 2202 & 0.10671 & $0.512994 \pm 8$ & 0.03257 & $0.703476 \pm 11$ \\
\hline 4 & BT-4 & 10.58 & 55.98 & 24.16 & 1857 & 0.11424 & $0.513004 \pm 7$ & 0.03761 & $0.703331 \pm 11$ \\
\hline 5 & BT-5 & 10.07 & 52.51 & 22.21 & 1781 & 0.11595 & $0.512992 \pm 5$ & 0.03605 & $0.703351 \pm 17$ \\
\hline 6 & BT-6 & 10.48 & 55.14 & 23.46 & 17.97 & 0.11485 & $0.513012 \pm 8$ & 0.03775 & $0.703312 \pm 12$ \\
\hline \multicolumn{10}{|c|}{ Anyui Volcano } \\
\hline 7 & $120 / 5$ & 5.38 & 18.38 & 9.38 & 464.2 & 0.17684 & $0.512827 \pm 5$ & 0.05847 & $0.704485 \pm 13$ \\
\hline 8 & $122 / 8$ & 5.58 & 19.60 & 10.61 & 465.0 & 0.17198 & $0.512860 \pm 9$ & 0.06598 & $0.704346 \pm 14$ \\
\hline 9 & $125 / 18$ & 6.09 & 23.03 & 14.53 & 527.6 & 0.15992 & $0.512902 \pm 5$ & 0.07966 & $0.703796 \pm 18$ \\
\hline \multicolumn{10}{|c|}{ Aluchin volcanoes } \\
\hline 10 & $48 / 1$ & 6.24 & 23.88 & 15.22 & 513.3 & 0.15784 & $0.513006 \pm 7$ & 0.08577 & $0.703512 \pm 19$ \\
\hline 11 & $105 / 1$ & 7.32 & 29.38 & 17.74 & 631.8 & 0.15056 & $0.512986 \pm 5$ & 0.08117 & $0.703589 \pm 11$ \\
\hline 12 & $110 / 8$ & 7.32 & 29.44 & 17.86 & 636.1 & 0.15036 & $0.512985 \pm 6$ & 0.08121 & $0.703618 \pm 23$ \\
\hline \multicolumn{10}{|c|}{ Pyatistennyi Volcano } \\
\hline 13 & $545 / 2$ & 7.59 & 32.58 & 55.66 & 848.3 & 0.14072 & $0.512884 \pm 5$ & 0.18978 & $0.704106 \pm 14$ \\
\hline \multicolumn{10}{|c|}{ Zhokhov Island basalts } \\
\hline 14 & $\mathrm{~J}-1$ & 8.55 & 38.18 & 22.55 & 935.8 & 0.13532 & $0.512959 \pm 9$ & 0.06970 & $0.703260 \pm 16$ \\
\hline 15 & $\mathrm{~J}-2$ & 8.56 & 38.73 & 24.97 & 1056.5 & 0.13355 & $0.512941 \pm 5$ & 0.06835 & $0.703340 \pm 35$ \\
\hline 16 & $\mathrm{~J}-3$ & 9.43 & 41.82 & 23.72 & 967.7 & 0.13624 & $0.512959 \pm 5$ & 0.07091 & $0.703206 \pm 12$ \\
\hline
\end{tabular}

Note: The isotope compositions were measured on the Finnigan MAT-261 mass spectrometer in the Institute of Geology and Geochemistry of the Precambrian, Russian Academy of Sciences (analyst B. V. Velyatskii). Sm, Nd, Rb, and Sr were analysed with the use of the method proposed by Richards et al. [1976]. Isotope composition measurement errors do not exceed $0.005 \%$ for $\mathrm{Sr}$ and $\mathrm{Nd}$, $0.5 \%$ for $\mathrm{Rb} / \mathrm{Sr}$, and $0.3 \%$ for $\mathrm{Sm} / \mathrm{Nd}$. The $\mathrm{Nd}$ isotope composition was corrected for the La Jolla standard value ${ }^{143} \mathrm{Nd} /{ }^{144} \mathrm{Nd}=$ 0.511860 , and the normalization to ${ }^{148} \mathrm{Nd} /{ }^{144} \mathrm{ND}=0.241570$ was made. The $\mathrm{Sm}, \mathrm{Nd}, \mathrm{Rb}$, and $\mathrm{Sr}$ concentrations are given in $\mathrm{g} / \mathrm{t}$.

The main structural elements of the folded basement of Northeast Asia had formed by the end of the Late Cretaceous, when both the subduction in the OkhotskChukotka belt [Parfenov, 1984] and collision within the Cherskii Range stopped. Their further development is associated with the initial peneplenization and formation of the weathering crust which lasted until the Miocene, when the new, platform stage of development began over most of the territory of Northeast Asia. The present structure of this region formed as a result of neotectonic movements that started at the Pliocene-Early Quaternary [Neotectonics..., 1989]. The position of volcanic centers indicates that Quaternary volcanism developed in diverse regions, such as the present platform (De-Longa Islands), rifting zone (Balagan-Tas volcano), and orogenic zone (Anyui, Bilibin, and Aluchin volcanoes). Taking into account that the compositions of the volcanic rocks are similar in petrochemical, geochemical, and isotopic characteristics and are typical of $\mathrm{Fe}-\mathrm{Ti}$ basalts, the absence of any relation of these rocks to tectonic regimes is evident. However, there is a circumstance that, in my opinion, is directly related to the localization of magmatic activity in the region considered; this is the proximity of Quaternary volcanic features to the boundary between the Eurasian and North American lithospheric plates.
The Eurasian basin of the Arctic Ocean, directly continuing the Norway-Greenland basin in the North Atlantic, started to open 56-55 Ma (anomaly 24, Lamont scale) [Karasik, 1980; Karasik et al., 1984; Pitman and Talwani, 1972]. Formation of the oceanic basin in the Arctic rearranged movements and changed the geodynamic style in the adjacent continental zone of Asia along the plate boundary. Figure 32 shows the rotation poles of the Eurasian and North American plates at various times, derived by various authors. Comparison of these data shows that the pole longitudes lie within the determination error, diverging by not more than $450-500 \mathrm{~km}$, whereas the differences in their latitudes are significant. The relative rotation pole of the Eurasian and North American plates was most reliably determined for the epoch of magnetic anomaly $2 \mathrm{~A}$ (3 Ma) in terms of the new global model NUVEL-1 [DeMets, 1992a, 1992b]. The position of this pole (point 7 in Figure 32) is close to the midpoint coordinates between the poles inferred in terms of models P071 [Chase, 1972] and RM2 [Minster and Jordan, 1978] (points 5 and 6 in Figure 32). The pole determined by Karasik [1980] for the last 4 Myr and the final pole constrained by our data (points 3 and 10 in Figure 32) are fairly close to the NUVEL-1 pole.

Notwithstanding the divergence in rotation pole determinations caused by both the accuracy of original data used at 


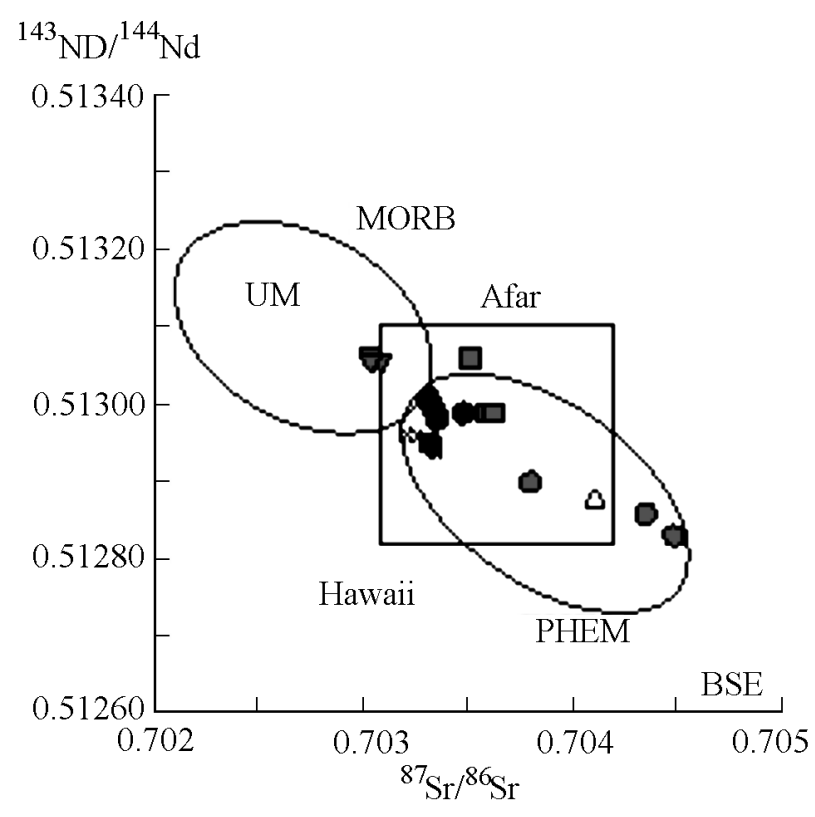

Figure 30. ${ }^{143} \mathrm{Nd} /{ }^{144} \mathrm{Nd}-{ }^{87} \mathrm{Sr} /{ }^{86} \mathrm{Sr}$ for compositions of the volcanics studied: UM, depleted upper mantle; PHEM, primordial helium-enriched mantle; BSE, homogeneous chondrite reservoir. Lava fields from mantle plumes of the Afar Triangle and Hawaii are shown. The rest of notation is the same as in Figure 22.

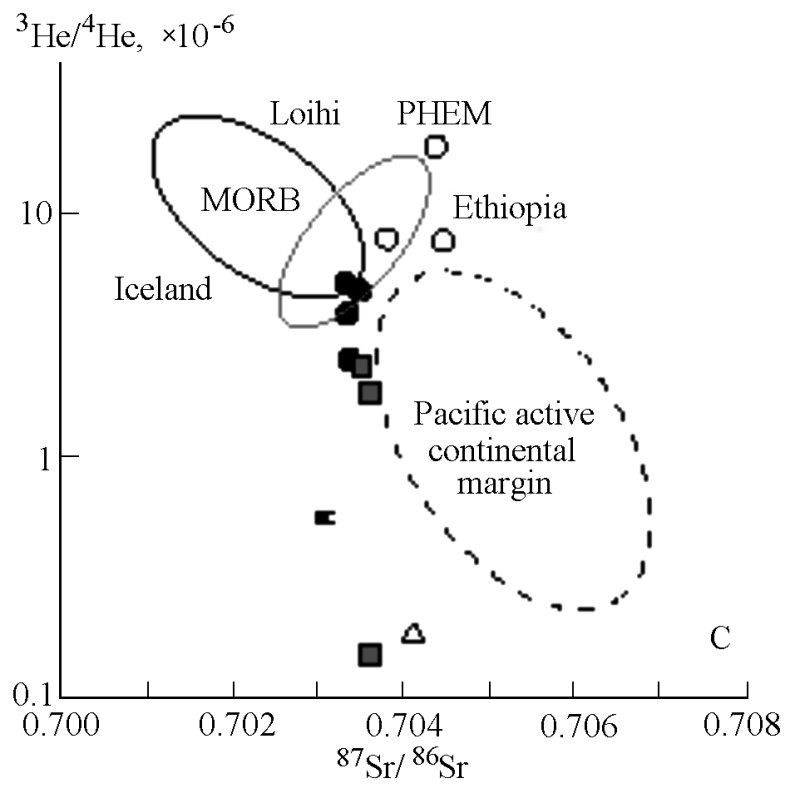

Figure 31. ${ }^{3} \mathrm{He} /{ }^{4} \mathrm{He}-{ }^{87} \mathrm{Sr} /{ }^{86} \mathrm{Sr}$ diagram for compositions of the volcanics studied. Lava fields are from oceanic mantle plumes of Loihi and Iceland, the continental Ethiopian plume [Marty et al., 1996], and volcanics of the active Pacific continental margin: C, continental crust; PHEM, primordial helium enriched mantle [Farley et al., 1992]; MORB, oceanic upper mantle [Zindler and Hart, 1986]. The rest of notation is the same as in Figure 22.

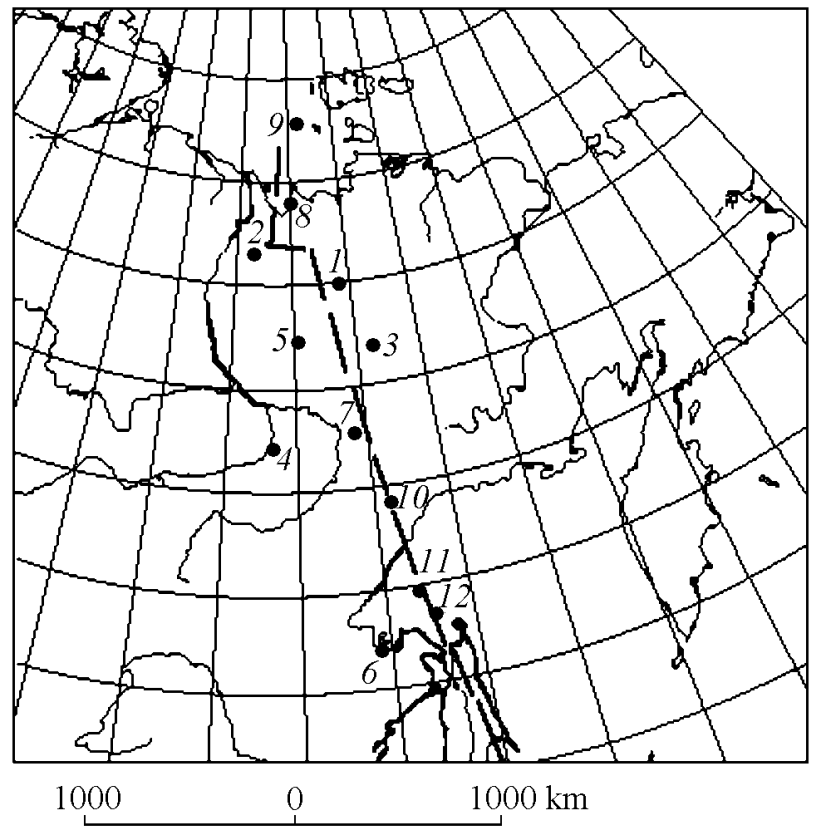

Figure 32. Poles of the Eurasian basin opening [Grachev, 1996]: (1) [Pitman and Talwani, 1972]; (2) [Minster, 1974]; (3) [Karasik, 1980]; (4) [Chapman and Solomon, 1976]; (5) [Minster and Jordan, 1978] (global pole); (6) [Chase, 1972]; (7) [DeMets, 1992a, 1992b]; (8) [Cook et al., 1986]; (9)-(12) [Grachev, 1996]; (9) from transform faults, (10) $55 \mathrm{Ma},(11) 26 \mathrm{Ma},(12) 15 \mathrm{Ma}$.

various times and differences in methods (magnetic anomalies, transform faults, and so on), the general tendency is the progressive southeastward motion of the pole with time (Figure 32). Karasik et al. [1984] distinguished four phases in the opening history of the Eurasian basin. Only the last of these, lasting from $4 \mathrm{Ma}$ to the present, is most relevant to our analysis. During this phase, when the present structure of Northeast Asia formed, the opening pole moved south into the area with coordinates $59.5^{\circ} \mathrm{N}, 142.5^{\circ} \mathrm{E}-59.6^{\circ} \mathrm{N}, 144.5^{\circ} \mathrm{E}$ [Karasik et al., 1984], and one of the most important results of this kinematic rearrangement in movements of the Eurasian and North American plates was the development of the Moma continental rift [Grachev, 1973, 1982, 1996; Grachev et al., 1967, 1970], within which the Balagan-Tas Volcano is located. As is noted by Burke [1984, p. 161), "the active volcanism in the Balagan-Tas area is helpful in defining the rifting limits at this time (from $9 \mathrm{Ma}$ to the present)".

Thus, whereas the origin of the Balagan-Tas Volcano might have been related to processes at the destructive boundary between the Eurasian and North American plate boundaries, the other volcanism features remain unexplained in terms of the structural control of the volcanism. However, in light of the above data on magmatism, the recent geodynamics of Northeast Asia needs insight into the driving mechanism responsible for simultaneous point-like lava erup- 
tions more than $1000 \mathrm{~km}$ apart rather than for the BalaganTas Volcano alone, as was done in my early works on the Moma rift.

As it is evident from the above bulk chemical analyses and data on geochemistry and isotopic composition of Quaternary lavas from Northeast Asia volcanoes, all of the volcanic rocks may be considered to have originated as a result of the melting of mantle plume material with weak contamination by lithospheric material. However, as distinct from the known mature plumes within the continental lithosphere, the geodynamic situation in Northeast Asia is probably unique in that we face here the very beginning of mantle plume origination, when columns of upwelling mantle material reach the base of the lithosphere. In this case, the volcanoes themselves may be regarded as potential triple junctions.

Such a model, when applied to the territory considered, not only adequately explains the present volcanism localization in Northeast Asia but also suggests the presence of still undiscovered (or future) magmatism features within an imaginary polygon defined by the known volcanoes. Possibly, the problematic volcanic feature in the Kedon River head area also belongs to this type if its Late Quaternary age is established.

On the other hand, many aspects of recent geodynamics in Northeast Asia can be naturally explained within the framework of the hypothesis offered. These are a complex and unsteady stress field; the southeastern Moma rift termination, topographically not expressed; and others. From the standpoint of plate tectonics, a breakup of continental lithosphere between the Eurasian and North American plates can occur only along a system of plumes, as was predicted by J. T. Wilson and as actually occurred in the past. Previously, I have noted that geodynamics of the Laptev Sea shelf zone, where the Mid-Ocean Gakkel Ridge advances into the Asian continent, may be called the pre-Afar stage [Grachev, 1982], and this makes the zone unique.

From the current state of lithospheric plate motions and plate boundary interactions [Henderson, 2001] the geodynamic situation in Northeast Asia does not fit into the accepted plate tectonics schemes. In the case under discussion we have a new type of plate boundaries that is not considered before. We propose that in Northeast Asia up to now there is an unknown type of the plate boundary induced by incipient mantle plume at the very beginning stage. All previous attempts to represent the boundary between the Eurasian and North American plates in linear form lose their meaning.

Acknowledgments. This work was supported by the Russian Foundation for Basic Research, Projects 01-05-64380 and 01-0564381 and Program No 5 of the Russian Academy of Sciences "Interaction of mantle plumes with lithosphere".

\section{References}

Akinin, V. V., and Yu. E. Apt, Enmelen Volcanoes, Chukotka Peninsula: Petrology of Alkali Lavas and Deep Inclusions, Magadan, 1994.
Albarede, F., How Deep Do Common Basaltic Magmas Form and Differentiate?, J. Geophys. Res., 97, 10997-11009, 1992.

Apt, Yu. E., V. V. Akinin, and J. E. Wright, $\mathrm{Sr}, \mathrm{Nd}$, and $\mathrm{Pb}$ Isotopes in Neogene Melanephelinite and Deep Xenoliths in Northeastern Russia, Petrologiya, (1), 1997.

Avetisov, G. P., Some problems of lithospheric dynamics of the Laptev Sea (in Russian), Fizika Zemli 5, 28-38, 1993.

Avetisov, G. P., Seismoactive Zones of the Arctic (in Russian), 185 pp., VNIIOkeanologiya, St. Petersburg, 1996.

Avetisov G. P., and V. S. Golubkov, Tectono-seismic zonation of the Arctic basin and adjacent regions, in Geology and mineral resources of the northern Siberian platform, Trudy, (8), 25-30, Nauchno-Issledovatel'skiy Institut Geologii Arktiki, Leningrad, 1971.

Azbel', I. Ya., and I. N. Tolstikhin, Radiogenic Isotopes and Evolution of the Earth's Mantle, Crust, and Atmosphere, Apatity, 1988.

Baranova, Yu. P., and S. F. Biske, Cenozoic evolution of the northeastern USSR, (in Russian), Nauka, Moscow, 1964.

Barazangi, M., and J. Dorman, Seismicity map of the Arctic compiled from ESSA Coast and Geodetic Survey, Epicenter data, 1961-1967, Seism. Soc. Amer. Bull., 59, (1), 369-380, 1969.

Bazarova, T. Yu., and M. A. Vavilov, Physicochemical Conditions of Crystallization of Anyui Volcano Basalts, Geol. Geofiz., (2), 46-50, 1989

Belyi, V. F., Ultrabasic Alkalic Volcanism of the Bering Volcanic Province, Chukotka, Tikhookean. Geol., (5), 65-77, 1998.

Bidjiev, R. A., and L. M. Natapov, On the occurrences of Cenozoic folding in Verkhoijanie (in Russian), Reports of the Acad. Sci. USSR, 205, 411-413, 1972.

Bogdanovskii, O. G., S. D. Mineev, S. S. Assonov, et al., Magmatism of the De Longa Archipelago, Eastern Arctic: Isotope Geochemistry and Geochronology, Geokhimiya, (1), 47-56, 1992.

Bogdanovskii, O. G., S. A. Silant'ev, S. F. Karpenko, et al., Ancient Mantle Xenoliths in Young Effusive Rocks of the Zhokhov Island, De Longa Archipelago, Dokl. Ross. Akad. Nauk, 330, (1), 750-753, 1993.

Bown, J. W., and R. S. White, Variarion with spreading rate of oceanic crustal thikness and geochemistry, Earth Planet. Sci. Lett., 121, 435-449, 1994.

Burke, K., Plate Tectonics History of the Arctic, Geology of the Arctic: Reports of the 27th International Geologic Congress, vol. 4, pp. 159-167, Nauka, Moscow, 1984.

Chapman, M. E., and S. C. Solomon, North American - Eurasian plate boundary in Northeast Asia, J. Geophys. Res., 81, 921930, 1976.

Chase, C. C., The N Plate Problem of Plate Tectonics, Geophys. J. R. Astron. Soc., 29, 117-122, 1972.

Chasovitin, M. D., New Data on Quaternary Intracontinental Volcanoes in Northeast Asia, Dokl. Akad. Nauk SSSR, 152, (3), 703-705, 1963.

Coakley, B. J., and J. R. Cochran, Gravity evidence of very thin crust at the Gakkel Ridge (Arctic Ocean), Earth Planet. Sci. Lett., 162, 81-95, 1998.

Conant, D. A., Six new focal mechanism solutions for the Arctic and a center of rotation for plate movements, Seism. Soc. Am. Bull., 63, 1120-1131, 1973.

Cook, D. B., K. Fujita, and C. A. McMullen, Present-day plate interactions in Northeast Asia: North American, Eurasian and Okhotsk plates, J. Geodyn., 6, 33-51, 1986.

Cox, C. J., J. D. Bell, and R. J. Pankhurst, Interpretation of Igneous Rocks, Nedra, Moscow, 1982.

DeMets, C., Oblique convergence and deformation along the Kuril and Japan trenches, J. Geophys. Res., 97, 17,615-17,625, 1992a.

DeMets, C., A test of present-day plate geometries for northeast Asia and Japan, J. Geophys. Res., 97, 17,627-17,635, $1992 \mathrm{~b}$.

DeMets, C., R. G. Gordon, D. F. Argus, and S. Stein, Current plate motions, Geophys. J. Int., 101, 425-478, 1990.

Dovgal', Yu. M., and M. D. Chasovitin, Bilibin Volcano: A New Quaternary Volcano in the Northeastern Kolyma Region, Geol. Geofiz., (6), 35-46, 1965.

Drachev, S. S., N. Kaul, and V. N. Beliaev, Eurasia spreading 
basin to Laptev Shelf transition: structural pattern and heat flow, Geophys. J. Int., 152, 688-698, 2003.

Drachev, S. S., L. A. Savostin, and I. E. Bruni, Structural pattern and tectonic history of the Laptev Sea region, in Reports on Polar Research (Berichte zur Polarforschung), Kassens, H., et al. (Eds.), Russian-German Cooperation: Laptev Sea System, Alfred Wegener Institute for Polar and Marine Research and the German Society for Polar Research, vol. 176, pp. 348-366, 1995.

Drachev, S. S., L. A. Savostin, V. G. Groshev, and L. E. Brini, Structure and geology of the continental shelf of the Laptev Sea, Eastern Russian Arctic, Tectonophysics, 298, 357-393, 1998.

Drubetskoi, E. R., and A. F. Grachev, He and Ar Isotope Distributions in Basalts and Ultrabasic Xenoliths of the Baikal Rift Zone, in Deep Xenoliths and Structure of the Lithosphere, pp. 54-63, Nauka, Moscow, 1987.

Eldholm, O., A. M. Karasik, and P. A. Reksnes, The North American plate boundary, in The Arctic Ocean Region, Grantz, A., Johnson, L., Sweeney, J. F. (Eds.), vol. L, pp. 171-184, Geological Society of America, Boulder, CO, 1990a.

Eldholm, O., J. Skogseid, E. Sundvor, and A. Myhre, The Norwegian-Greenland Sea, in The Arctic Ocean Region, Grantz, A., Johnson, L., Sweeney, J. F. (Eds.), vol. L, pp. 351364, Geological Society of America, Boulder, CO, 1990b.

Farley, K. A., J. H. Natland, and H. Craig, Binary mixing of enriched and undegassed (primtive) mantle components (He, Sr, Nd, Pb), Earth Planet. Sci. Lett., 111, 183-199, 1992.

Franke, D., F. Kruger, and K. Klinge, Tectonics of the Laptev Sea - Moma Rift region: investigation with seismological broadband data, J. Seismology, 4, 99-116, 2000.

Fujita, K., F. W. Cambray, and M. A. Velbel, Tectonics of the Laptev Sea and Moma rift systems, northeastern USSR, Mar. Geol., 93, 95-118, 1990a.

Fujita, K., D. B. Cook, H. Hasegava, D. Forsyth, and R. Wetmiller, Seismicity and focal mechanisms of the Arctic Region and the North American plate boundary in Asia, in The Arctic Ocean Region, Grantz, A., Johnson, L., Sweeney, J. F. (Eds.), vol. L, pp. 79-100, Geological Society of America, Boulder, CO, 1990b.

Fujita, K., F. W. Cambray, and M. A. Velbel, Tectonics of the Laptev Sea and the Moma Rift Systems, Arctic Geoscience (A. F. Weber et al., Eds.), Marine Geology, (93), 95-118, 1993.

Gaiduk, V. V., O. V. Grinenko, V. S. Imaev, I. Sh. Sindukov, and Ja. Ja. Gakkel, Science and exploration of Arctic, 133 pp. (in Russian), Sea Transport, Leningrad, 1957.

Gaina, C., W. R. Roest, and R. D. Muller, Late CretaceousCenozoic deformation of northeast Asia, Earth Planet. Sci. Lett., 197, 273-286, 2002.

Gakkel, Ja. Ja., Science and exploration of Arctic (in Russian), Sea Transport, Leningrad, 133 pp., 1957.

Geology of the USSR, vol. 26, Gosgeolizdat, Moscow, 1970.

Ginzburg, L., Notebooks, memoires, p. 12, St.-Petersburg, Art, 2002.

Grachev, A. F., Geophysical Exploration Methods in Arctic, issue 8, 56-75, 1973.

Grachev, A.F., Rift zones of the Earth, 238 p., Nedra, Moscow, 1977.

Grachev, A. F., Geodynamics of the Transitional Zone from the Moma Rift to theakkel Ridge, in Studies in Continental Margin Geology, Watkins, J. S., Drake, C. L. (Eds.), Am. Assoc. Petrol. Geol. Mem., vol. 34, pp. 103-114, 1982.

Grachev, A. F., Rift Zones of the Earth, 2nd ed., Nedra, Moscow, 1987.

Grachev, A. F., Evolution of Basaltic Volcanism during the Earth's History, Fiz. Zemli, (8), 91-114, 1991.

Grachev, A. F., Main Problems of Neotectonics and Geodynamics of North Eurasia, Fiz. Zemli, (12), 5-36, 1996.

Grachev, A. F., Recent Volcanism, Neotectonics of North Eurasia, pp. 106-116, Geos, Moscow, 1998a.

Grachev, A. F., Khamar-Daban as a Hotspot of the Baikal Rift: Evidence from Chemical Geodynamics, Izv. Akad. Nauk SSSR, Fiz. Zemli, (3), 3-29, 1998b.

Grachev, A. F., Mantle Plumes and Geodynamics, Vestn.
OGGGGN Ross. Akad. Nauk, 3, (5), 129-158, 1998c.

Grachev, A. F., and A. M. Karasik, Sea-floor spreading and plate tectonics of the Eurasian Basin of the Arctic Ocean (in Russian), Geotectonic prerequisite for mineral prospecting on the Arctic Shelf, pp. 19-33, NIIGA, Leningrad, 1974.

Grachev, A. F., and V. I. Mishin, Costruction of neotectonic maps on the basis of trend analysis, Geomorfologia, (2), 63-70, 1975. Grachev, A. F., and G. D. Naryshkin, Main features of sea-floor topography of the Eurasian basin of the Arctic ocean, Vestnik Leningradskogo Universiteta, Geologia and Geografia, (12), 94102, 1978.

Grachev, A. F., R. M. Demenitskaya, and A. M. Karasik, MidOcean Arctic Ridge and its Continental Extension, Geomorfologiya, (1), 42-45, 1970.

Grachev, A. F., R. M. Demenitskaya, and A. M. Karasik, Relation of the Moma Continental Rift to the Gakkel Ridge Structure, Geophysical Exploration Methods in Arctic, pp. 48-50, Leningrad, 1971.

Grachev, A. F., S. S. Ivanov, A. M. Karasik, and S. A. Ushakov, On the Arctic Rift System, Uch. Zap. Nauchno-Issled. Inst. Geol. Arkt. Reg. Geol., issue 10, pp. 65-70, 1967.

Grachev, A. F., E. R. Drubetskoi, L. K. Levskii, et al., BalaganTas Volcano Basalts as a Result of Melting of a Unique Homogeneous Reservoir, XIII Symp. on Isotope Geochemistry, pp. 56-58, Moscow, 1992.

Grachev, A. F., et al., Neotectonics, geodynamics and seismicity of Northern Eurasia, 489 pp., Probel, Moscow, 2000.

Gramberg, I. S., R. M. Demenitskaya, and S. B. Sekretov, 1990. The Laptev shelf system of rift grabens as a lacking link in the Gakkel-Moma Rift chain (in Russian), Dokl. Acad. Nauk USSR, 311, 689-694, 1990.

Green, D., and A. Ringwood, Petrology of the Upper Mantle, Canberra, 1966, Translated under the title Petrologiya verkhne mantii, Mir, Moscow, 1968.

Hards, V. L., P. D. Kempton, and R. N. Thompson, The Heterogeneous Iceland Plume: New Insights from the Alkaline Basalts of the Snaefell Volcanic Centre, J. Geol. Soc. (London), 152, (6), 1003-1009, 1995.

Heezen, B. C., and M. Ewing, The Mid-Oceanic Ridge and its extension through the Arctic basin, in Geology of the Arctic, pp. 374-398, Toronto Univ. Press, Toronto, 1961.

Henderson, D. M., New visualizations of global tectonic plate motions and plate boundary interactions, Terra Nova, 13, 70-78, 2001

Imaev, V. S., L. P. Imaeva, and B. M. Koz'min, Active Faults and Seismic Tectonics of the Northeastern Yakutia (in Russian), 140 pp., Scientific Center of Siberian Department of Academy of Science of USSR, Yakutsk, 1990.

Ivanova, N. M., S. B. Sekretov, and S. I. Shkarubo, Data on the geological structure of the Laptev shelf from the seismic survey (in Russian), Oceanology, 29, 789-795, 1989.

Ichetovkin, N. V., A. D. Silinskii, and A. P. Fadeev, Cenozoic Alkali Basaltoids from the Kananyga and Viliga River Basins (Okhotsk-Chukotka Volcanic Belt), Geol. Geofiz., (8), 127$132,1970$.

Jensen, L. S., A New Cation Plot for Classifying Subalkalic Volcanic Rocks, Miscellaneous Paper 66, Ontario Department of Mines, 1976.

Jokat, W., E. Weigelt, Y. Kristoffersen, Th. Rasmussen, and T. Schone, New insights into the evolution of the Lomonosov Ridge and the Eurasian Basin, Geophys. J. Int. 122, 378-392, 1995a.

Jokat, W., E. Weigelt, Y. Kristoffersen, Th. Rasmussen, and T. Schone, New geophysical results from the south-western Eurasian Basin (Morris Jesup Rise, Gakkel Ridge, Yermak Plateau) and the Fram Strait, Geophys. J. Int., 123, 601-610, 1995b.

Karasik, A. M., Magnetic anomalies of the Gakkel Ridge and origin of the Eurasia Subbasin of the Arctic Ocean (in Russian), in Geophysical Methods of Prospects in Arctic, vol. 5, pp. 8-25, Leningrad, 1968.

Karasik, A. M., The Eurasia Basin of the Arctic Ocean from the point of view of plate tectonics (in Russian), in Problems 
in Geology of Polar Areas of the Earth, pp. 23-31, NauchnoIssledovatel'skii Institut Geologii Arktiki, Leningrad, 1974.

Karasik, A. M., Major Aeromagnetic Constraints on the Development of the Sea-Floor Structure in the Arctic Basin, Marine Geology, Sedimentology, Petrography of Sediments, and Oceanic Geology, pp. 178-193, Nedra, Leningrad, 1980.

Karasik, A. M., and A. F. Grachev, Structure on the crust of oceanic type, in Explanotory notes to the tectonic map of the North Polar region of the Earth, pp. 178-193, NauchnoIssledovatel'skiy Institut Geologii Arktiki, Leningrad, Trudy, 1977.

Karasik, A. M., V. I. Ustritskii, and A. N. Khramov, Formation History of the Arctic Ocean, 27th Int. Geol. Congr. Reports, vol. 4, pp. 151-159, Nauka, Moscow, 1984.

Kim, B. I., Structural continuation of the Gakkel Ridge rift valley on the Laptev shelf (in Russian), Structure and a History of Development of the Arctic Ocean, pp. 133-139, PGO "Sevmorgeologia", Leningrad, 1986.

Kogan, A. L., Seismic studies using CVRW and DSS from marine ice on the Arctic sea shelf (exemplified by the Laptev Sea), in Geophysical Surveys in the Arctic, pp. 33-38, NauchnoIssledovatel'skiy Institut Geologii Arktiki, Trudy, 1974.

Kovacs, L., Residual magnetic anomaly chart of the Arctic ocean region, US Naval Res. Lab. Scale 1:6 000 000. 1983.

Koz'min, B. M., Main stresses in earthquake foci of the northeast USSR, in New data on geology of Yakutia, pp. 117-125, Yakutsk, 1975.

Koz'min, B. M., Seismic belts of Yakutia and focal mechanisms of earthquakes, 126 pp. (in Russian), Nauka, Moscow, 1984.

Kristoffersen, Y., Eurasia basin, in The Arctic Ocean Region, Grantz, A., Johnson, L., Sweeney, J. F. (Eds.), vol. L, Geological Society of America, Boulder, CO, pp. 365-378, 1990.

Kristoffersen, Y., and M. Talwani, Extinct triple junction south of Greenland and the Tertiary motion of Greenland relatively to North America, Geol. Soc. Am. Bull. 88, 1037-1049, 1977.

Larson, K. M., J. T. Freymueller, and S. Philipsen, Global plate velocities from the Global Positioning System, J. Geophys. Res., 102, 9961-9981, 1997.

Le Pichon, X., Sea-Floor Spreading and Continental Drift, J. Geophys. Res., 73, 3661-3698, 1968.

Le Pichon, X., J. Francheateau, and J. Bonin, Plate tectonics, 300 pp., Elsevier, Amsterdam, 1973.

Le Roex, A. P., H. I. B. Dick, A. J. Erlank, A. M. Reid, F. A. Frey, and S. R. Hart, Geochemistry, Mineralogy and Petrogenesis of Lavas Erupted along the South-Western Indian Ridge between the Bouvet Triple Junction and 11 Degrees East, J. Petrol., 24, 267-318, 1983.

Macdonald, G. A., and T. Katsura, Chemical Composition of Hawaiian Lavas, J. Petrol., 5, 82-133, 1964.

MacGregor, J., The system $\mathrm{MgO}-\mathrm{SiO}_{2}-\mathrm{TiO}_{2}$ and its Bearing on the Distribution of $\mathrm{TiO}_{2}$ in Basalts, Am. J. Sci., 267, 342-363, 1969.

McKenzie, D., and R. L. Parker, The North Pacific-An Example of Tectonics on a Sphere, Nature, 216, p. 1276, 1967.

Malevsky, A. V., and D. A. Yuen, Plume Structures in the Hard-Turbulent Regime of Three-Dimensional Infinite Prandtl Number Convection, Geophys. Res. Lett., 20, 383-386, 1993.

Marty, B., R. Pik, and Y. Gezahegn, Helium Isotopic Variations in Ethiopian Plume Lavas: Nature of Magmatic Sources and Limit on Lower Mantle Contribution, Earth Planet. Sci. Lett., 144, 223-237, 1996.

Merzliakov, B. M., Stratigraphy and tectonics of the Omulev highland, 152 pp., Nedra, Moscow, 1971.

Mezvilk, A. A., and G. A. Murzina, Joints on Siberian platform, in Geolgy and gas possibilities of thr Soviet Arctic, pp. 82-86, Nauchno-Issledovatel'skiy Institut Geologii Arktiki, Leningrad, Trudy, 1972.

Minster, I. B., Numerical Modeling of Instantaneous Plate Tectonics, Geophys. J. R. Astron. Soc., 36, 541-576, 1974.

Minster, J. B., and T. H. Jordan, Present day plate motions, J. Geoph. Res., 83, 5331-5354, 1978.

Mokshanzev, K. B., G. S. Gusev, and A. F. Petrov, Geological criteria of seismicity on the territory of Yakutia (in Russian), in Seismic zoning of Yakutia and adjacent territories, pp. 4763, Yakutsk, 1975.

Muhe, R., C. W. Devey, and H. Bohrmann, Isotope and trace element geochemistry of MORB from the Nansen-Gakkel ridge at 860 North, Earth Planet. Sci. Lett., 120, 103-109, 1993.

Muhe, R., H. Bohrmann, D. Garbe-Schonberg, and H. Kassens, E-MORB glasses from the Gakkel Ridge (Arctic Ocean) at $87^{\circ} \mathrm{N}$ : evidence for the Earth's most northerly volcanic activity, Earth Planet. Sci. Lett., 152, 1-9, 1997.

Naimark, A. A., The Moma rift zone (northeastern USSR) (in Russian), in Neotectonics, recent sediments and man, pp. 351, Moscow University Press, Moscow, 1980.

Neotectonics of North Eurasia, Geos., Moscow, 1989.

Oxman, V. S., Tectonic evolution of the Mesozoic VerkhoyanskKolyma belt (NE Asia), Tectonophysics, 365, 45-76, 2003.

Paleogeographic atlas of the shelf regions of Eurasia for the Mezosoic and Cenozoic, vol. 1 and 2, Robertson Group Publ., 1991.

Paleogene and Neogene of the North Eastern part of the USSR, 183 p., Yakutsk, 1989.

Parfenov, L. M., Continental Margins and Island Arcs in the Mesozoids of Northeast Asia, Nauka, Novosibirsk, 1984.

Parfenov, L. M., B. M. Koz'min, O. V. Grinenko, V. S. Imaev, and L. P. Imaeva, Geodynamics of the Chersky seismic belt, $J$. Geodyn, 9, 15-37, 1988.

Parfenov, L. M., A. V. Prokopiev, and V. V. Gaiduk, Cretaceous frontal thrusts of the Verkhoyansk fold belt, eastern Siberia, from the Late Cretaceous to the early Tertiary, Tectonics, 14, 342-358, 1995.

Patyk-Kara, N. G., and M. A. Grishin, A location of the Poyusny ridge in the structure of the northeast USSR and its recent tectonics, Geotectonika, (4), 90-98, 1972.

Piskarev, A. L., A. V. Manuhova, and M. Yu. Chernyshev, Geodynamic system of the Laptev Sea based on the analysis of the gravity and magnetic anomalies (in Russian), Dokl. Acad. Nauk Russia, 354, 230-233, 1997.

Pitman, W. C. III, and M. Talwani, Sea-Floor Spreading in the North Atlantic, Geol. Soc. Am. Bull., 83, 619-646, 1972.

Plate Tectonics, 563 pp., W.: Am. Geoph. Un., 1972.

Poreda, R., and H. Craig, Helium Isotope Ratios in CircumPacific Volcanic Arcs, Nature, 338, 473-478, 1989.

Rachor, E. (Ed.), Scientific Cruise Report of the Arctic expedition ARK-XI/1 of R/V "Polarstern" in 1995, Germany, Bremenhaven, AWI, Berichte zur Polarforchung, (226), 330 p., 1997.

Rare Earth Element Geochemistry, Elsevier, Amsterdam, 1984.

Richard, P., N. Shimizu, and C. J. Allegre, ${ }^{143} \mathrm{Nd} /{ }^{144} \mathrm{Nd}$ a Natural Tracer, An Application to Oceanic Basalts, Earth Planet. Sci. Lett., 31, 269-278, 1976.

Roeser, H. A., M. Block, K. Hinz, and C. Reichert, Marine geophysical investigations in the Laptev Sea and western part of the East Siberian Sea, in Reports on Polar Research (Berichte zur Polarforschung), Russian-German Cooperation: Laptev Sea System, Kassens H. et al. (Eds.), Alfred Wegener Institute for Polar and Marine Research and the German Society for Polar Research, vol. 176, pp. 367-377, 1995.

Rowley, D. B., and A. L. Lottes, Plate-kinematic reconstructions of the North Atlantic and Arctic Late Jurassic to present, Tectonophysics, 155, 73-120, 1988.

Rudich, K. N., The Late Quaternary Balagan-Tas Volcano, Recent Volcanism of Northeastern Siberia, pp. 3-44, Nauka, Moscow, 1964.

Rudich, K. N., and E. K. Ustiev, Quaternary Volcanism Centers in the Northeast Asia Mesozoids, Volcanic and Plutonic Formations, vol. 2, pp. 93-107, Nedra, Moscow, 1966.

Rzhevsky, N. N., On the question of anomalous magnetic field on the southern part of the Gakkel ridge, in Tectonics of the Arctic, no. 1, pp. 18-20, Nauchno-Issledovatel'skiy Institut Geologii Arktiki, Leningrad, Trudy, 1975.

Saggerson, E. P., and L. A. J. Williams, Ngurumanite from Southern Kenya and its Bearing on the Origin of Rocks in the Northern Tanganyika Alkaline District, J. Petrol., 5, 40-81, 1964.

Savostin, L. A., S. A. Silant'ev, and O. G. Bogdanovskii, New Evi- 
dence on Volcanism of the Zhokhov Island, De Longa Archipelago, Arctic Basin, Dokl. Akad. Nauk SSSR, 302, (6), 1443-1447, 1988.

Schilling, J.-G., M. Zajac, R. Evance, et al., Petrologic Variations along the Mid-Atlantic Ridge from $29^{\circ} \mathrm{N}$ to $73^{\circ} \mathrm{N}, A m$. J. Sci., 283, 510-586, 1983.

Schilling, J.-G., R. H. Kingsley, B. B. Hanan, and B. L. McCully, $\mathrm{Nd}-\mathrm{Sr}-\mathrm{Pb}$ Isotopic Variations along the Gulf of Aden: Evidence for Afar Plume-Continental Lithosphere Interaction, $J$. Geophys. Res., 97, 10,927-10,966, 1992.

Sekretov, S. B., Tectonics of the southeastern termination of the Eurasia Basin, Arctic Ocean (in Russian), Dokl. Acad. Nauk Russia, 367, 660-663, 1999.

Sekretov, S. B., Structure and tectonic evolution of the southern Eurasia Basin, Arctic Ocean, Tectonophysics, 351, 193-243, 2002.

Silant'ev, S. A., O. G. Bogdanovskii, L. A. Savostin, and N. N. Kononkova, Magmatism of the De Longa Archipelago, East Arctic: Petrology and Petrochemistry of Effusive Rocks and Associated Xenoliths (Zhokhov and Vil'kitskii Islands), Geokhimiya, (2), 267-276, 1991.

Srivastava, S. P., Evolution of the Eurasian Basin and its implication to the motion of Greenland along Nares Strait, Tectonophysics, 114, 29-53, 1985.

Srivastava, S. P., and C. R. Tapscott, Plate kinematics of the North Atlantic, in The Western North Atlantic Region, P. R. Vogt, B. E. Tucholke (Eds.), The Geology of North America M, Geol. Soc. Am., pp. 379-405, 1986.

Sun, S. S., Chemical Composition and Origin of the Earth's Primitive Mantle, Geochim. Cosmochim. Acta, 6, 179-192, 1982.

Sykes, L., Earthquake swarms and sea-floor spreading, J. Geophys. Res., 32, 6598-6611, 1970.

Taylor, S. R., and S. M. McLennan, The Continental Crust, its Composition and Evolution, Blackwell, Oxford, 1985.

Trushkov, Ju. N., Formation and development of alluvial placers in Mesozoids of Yuakutia, 235 pp., Nauka, Moscow, 1972.

Ustiev, E. K., The Anyui Volcano and Problems of Quaternary Volcanism in the Northeast USSR, Gosgeoltekhizdat, Moscow, 1961.

Van Doover, C. L., C. R. German, K. G. Speer, et al., Evolution and biogeography of deep-sea vent and deep unvertedrate, Science, 295, 1253-1257, 2002.

Vas'kovskii, A. P., The Quaternary Balagan-Tas Volcano in the Moma River Head Area, Proc. Volcanol. Lab. Kamchatka Volcanol. Station, no. 6, 1949.

Vinogradov, V. A., G. I. Gaponenko, I. S. Gramberg, and V. N. Shimaraev, Structural and formation complexes of the Arctic shelf of the East Siberia (in Russian), Sov. Geol., 9, 23-28, 1976.

Vinogradov, V. A., Laptev Sea (in Russian), in Geological Structure of the USSR and Regularities of Minerals Distribution,
Soviet Arctic Seas, vol. 9, Gramberg, I. S., Pogrebitskiy, Yu. E. (Eds.), pp. 50-60, Nedra, Leningrad, 1984.

Vinogradov, V. A., G. I. Gaponenko, I. M. Rousakov, and V. N. Shimaraev, Tectonics of the East Arctic Shelves of the USSR (in Russian), NIIGAWorks, vol. 171, 144 pp., Nedra, Leningrad, 1974.

Vogt, P. R., P. T. Taylor, L. C. Kovacs, and G. L. Johnson, Detailed aeromagnetic investigations of the Arctic Basin, J. Geophys. Res., 84, 1071-1089, 1979.

Vogt, P., C. Bernero, L. Kovacs, and P. Taylor, Structure and plate tectonic evolution of the marine Arctic as revealed by aeromagnetics, Oceanologica Acta, (SP), 25-40, 1981.

Wallace, J. M., R. M. Ellam, I. G. Meighan, et al., Sr Isotope Data for the Tertiary Lavas of Northern Ireland: Evidence for Open System Petrogenesis, J. Geol. Soc. (London), 151, 869-877, 1994.

Weigelt, E., and W. Jokat, Peculiarities of roughness and thickness of oceanic crust in the Eurasian Basin, Arctic Ocean Geophys. J. Int., 145, 505-516, 2001.

Wood, D. A., The Application of a Th-Hf-Ta Diagram to Problems of Tectonomagmatic Classification and to Establishing the Nature of Crustal Contamination of Basaltic Lavas of the British Tertiary Volcanic Province, Earth Planet. Sci. Lett., 50, 11-30, 1980.

Yang, H.-J., and F. A. Frey, Submarine Lavas from Mauna Kea Volcano, Hawaii: Implications for Hawaiian Shield Stage Processes, J. Geophys. Res., 99, (8), 15,577-15,594, 1994.

Yoder, H., and C. Tilley, Origin of Basalt Magmas, London, 1962, Translated under the title Proiskhozhdenie bazal'tovykh magm, Mir, Moscow, 1965.

Yo-ichiro Otofuji, Takaaki Matsuda, Ryo Enami et al., Late Cretaceous palaeomagnetic results from Sikhote Alin, far eastern Russia: tectonic implications for the eastern margin of the Mongolia Block, Geophys. J. Int., 152, 202-214, 2003.

Zindler, A., and S. Hart, Chemical geodynamics, Ann. Rev. Earth Planet. Sci., 14, 493-571, 1986.

Zoback, M. L., First- and second-order patterns of stress in the lithosphere: The World Stress Map Project, J. Geophys. Res., 97, 11,703-11,728, 1992

Zonenshain, L. P., and L. A. Savostin, Introduction to geodynamics, 312 pp. (in Russian), Nedra, Moscow, 1979.

Zonenshain, L. P., L. M. Natapov, L. A. Savostin, and A. P. Stausuii, Recent plate tectonics of northeastern Asia in connection with the opening of the North Atlantic and Arctic Ocean Basins, Oceanology, 18, 550-555, 1978.

A. F. Grachev, United Institute of Physics of the Earth, Russian Academy of Sciences, Moscow e-mail: grachev@uipe-ras.scgis.ru

(Received 25 September 2003) 